Historic, Archive Document

Do not assume content reflects current scientific knowledge, policies, or practices. 

62.39

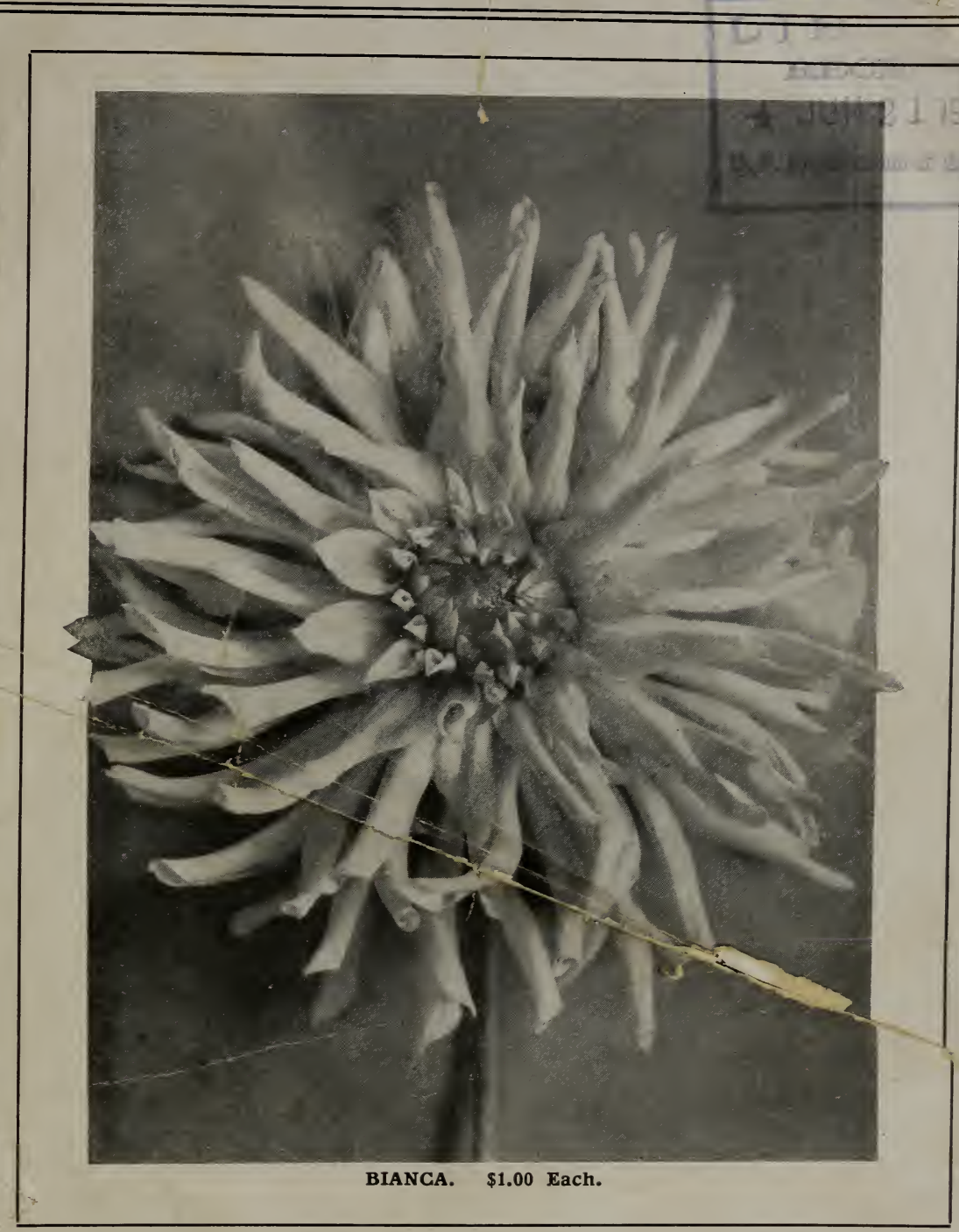

CULTURAL GUIDE AND CATALOG FOR 1920 J. K. ALEXANDER THE DAHLIA 547-559 CENTRAL :TREET KING EAST BRIDGEW ATER, MASSACHUSETTS 


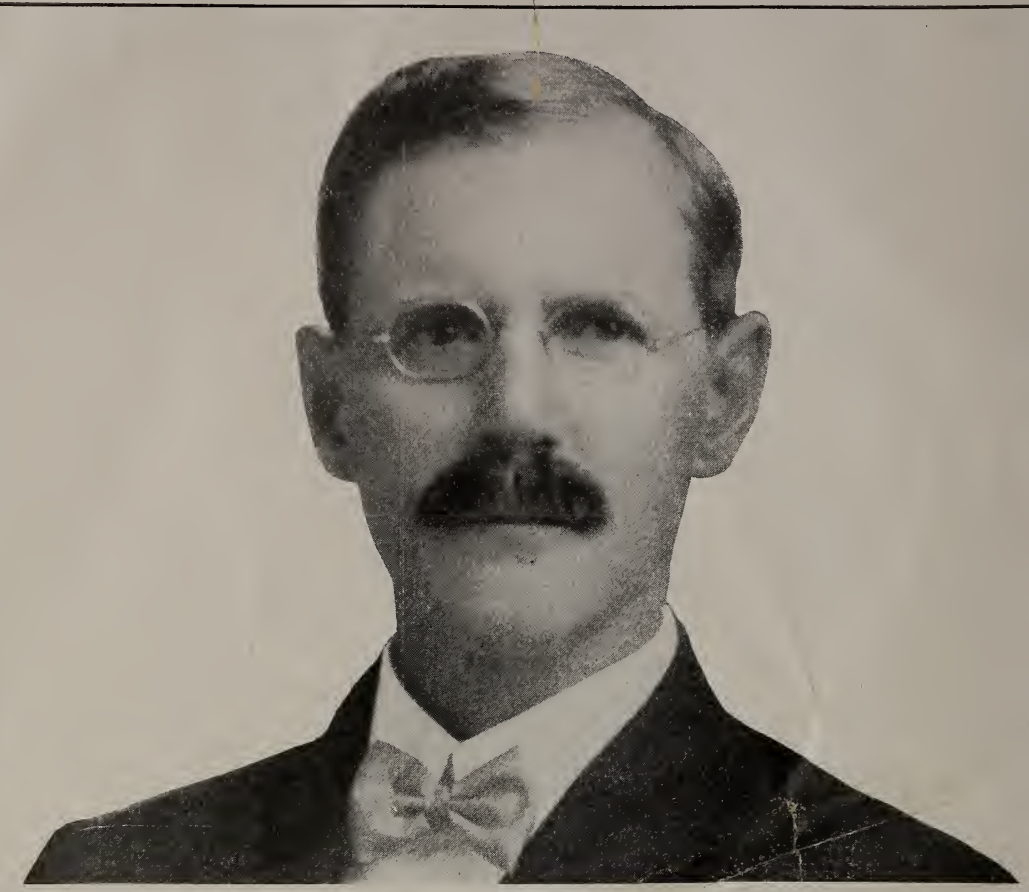

J. K. ALEXANDER

I print this not because $I$ am proud of my own picture, but because most people like to see the man whom they are doing business.

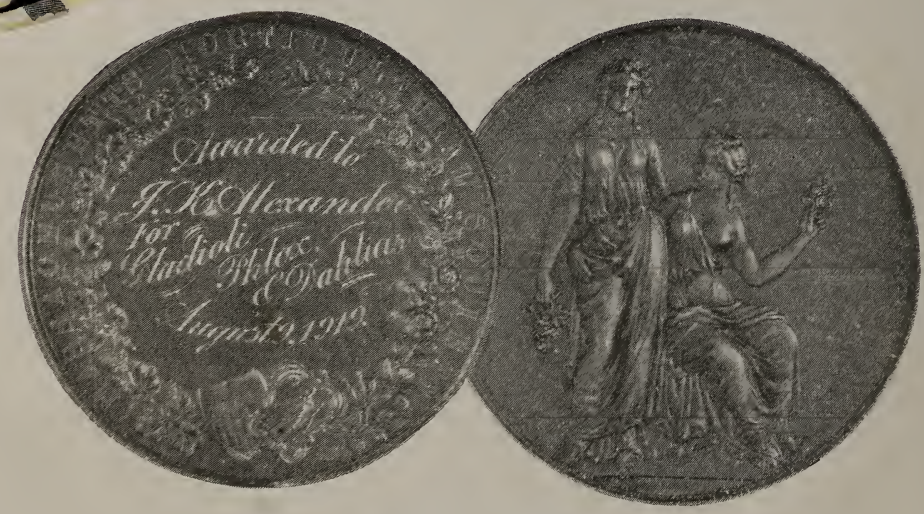

SILVER MEDAL

Awarded me for display of Gladioli, Phlox and Dahlias. Exhibition of the Massachusetts Horticultural Society, Boston, Mass., August 19, 1919. 


\section{A Talk With My Friends and Patrons}

I

TAKE great pleasure in presenting you with a copy of my new 1920 Catalogue which I feel is a great improvement over my last issue. I also take this opportunity of thanking my many friends and patrons who have recommended and favored me with their orders in the past, and to express gratification that my determination to furnish none but the best stock, is so widely recognized.

Six years ago I constructed a storage and shipping plant which is a great advantage to myself and customers. Under my present system I am able to ship stock from the time we finish digging, about November 15th, till July 1st the following year.

This building has a cement cellar containing 11,700 cubic feet of storage room and 4,680 square feet of floor space. It is the largest building of the kind in the world. I especially invite all my friends and customers to make a personal inspection of my plant.

I have been acknowledged the largest Dahlia grower in the world. This last season I grew over 4,500,000 Dahlia plants-nearly 40 acres. I feel that this will be of great interest to the general public who have in past years come along distances to visit $\mathrm{my}$ fields in the flowering season, through the months of August and September. My fields are kept open at all times for the inspection of the public. Visitors are always welcome. I am pleased at any time to assist the public with any information possible, provided they will send return stamp.

My growing exhibits at the World's Fair, St. Louis Purchase Exposition, Jamestown Exposition, Alaska-Yukon-Pacific Exposition, and PanamaPacific Exposition, won honors of highest degree, acknowledging my stock universally unsurpassed.

The past season I made more exhibits than ever before in the different states, winning first prize in all of them. I dare say I won more prizes than any other firm in America in the past season.

It is unnecessary to say anything regarding the exhibits I have made at the different horticultura and agricultural societies in the past. Every person that ever saw my exhibit knows that it was fully as good, if not the best that was ever made in the place where I exhibited.

If you are looking for some first class, up-to-date Dahlias, do not hesitate in placing your order in the hands of a firm who has been doing business for 25 years, and will give you good satisfaction for your money. My stock is strong, separated, field-grown clumps, with one or two eyes on a bulb, and guaranteed true to name. Although my stock is not overgrown, it is considered much the better for amateur growers, as the stock has not been forced to any overgrowth, which is very apt to take out of the stock rather than add anything to its value. Many large firms recommend and sell mostly Dahlia plants, and charge as much for them as strong roots; they are all right for a professional who understands the handling of them and wishes to build up a stock quickly, but I would not recommend them to the amateur. If cut off by an insect the plant is lost, but it is not so with bulbs. The sprout from a bulb if cut off by an insect will come again with two sprouts. so one does not feel as if he had paid out good money for stock and at the end of the season had nothing to bulbs with good eyes or sprouts, do not always grom: so, if any of my customers, after purchasing any of my bulbs, should have any of them fail to grow after planting then, dig them up and mail them back with the label on them, and I will remail you one in place of them; but, do not remail stock you have purchased elsewhere, as this has happened in some cases.

I would recommend that customers order early as my orders are booked in rotation and shipped accordingly. My stock is tested before being shipped to my customers. I shall take as much pains in the future as in the past to send out nothing but first-class stock and to continue the same prompt. liberal and conscientious dealings. Hoping to receive a share of your patronage this coming season, I remain,

Respectfully yours,

\section{J. K. ALEXANDER, The Dahlia King \\ (Copyrighted)}

East Bridgewater, Mass.

January $1,1920$.

Long Distance Telephone Connection. 


\section{History of the Dahlia}

The Dahlia is a native of Mexico, where it grew wild, and in its single state. Earliest history dates back to 1657, when it was called Acoctli by the Aztec Indians. Later the name was changed to Georgiana, after Professor Georgi of St. Petersburg, which name is still used in some of the foreign catalogues. It was again changed to Dahlia, in honor of Dr. Andrew Dahl, a Swedish botanist.

The Dahlia was first cultivated in the Botanic Gardens, at Madrid, Spain, in 1789, and at about the same time was introduced into England by the Marchioness of Bute.

Dahlia Variabilis, from which most of the common or Show Dahlias have originated, was single in its wild state. The first double forms appeared

in 1814 and were credited to M. Donkelaar, of the Botanical Gardens of Belgium. The Pompon form appeared about 1858, followed by the Decorative, the origin of which is not clearly defined, but probably dates back some 40 or 50 years. Dahlia Jaurezi, the first of Cactus Dahlia, was discovered in Juxphaor Mexico, in 1872 , by J. T. Vanderberg, and named Juarezi in honor of President Jarez of Mexico. It was sent by Vanderberg to an English florist, who exhibited it in England in 1880 .

Dahlia tubers or bulbs were used as a food in Mexico, and at one time in France. It was attempted to introduce them into cultivation in all Europe as a food for either man or cattle, but the taste was found nauseous to European palates.

\section{The Culture of the Dahlia}

\section{Success Will Follow If You Observe These Instructions}

LOCATION. The Dahlia is not as particular as most of our flowers, and will succeed under a great many adverse conditions. There are, however, certain locations where Dahlias seem to outdo themselves. An open sunny location seems to favor them at all times. Dahlias do well on high and low land, on hillsides or perfectly level land, giving good results in each location.

I find Dahlias are particularly adapted for seashore use, and not only do well, but thrive, for the reason of the moisture, and principally the heavy dews which collect during the nights.

I also find that many varieties do well in partial shade, producing fully as good flowers as they do in the hot sun, especially for exhibition purposes.

Dahlias will grow and do equally well in any kind of soil. I have sand, gravel, heavy and light loam, low land and hills, and find very little difference, as far as the number of flowers are concerned, the only difference being that in sand and gravel they form a short, sturdy, compact plant, and in heavy loam and low land they grow tall and rank, blossoming about a week later than those planted at the same time in sandy soil.

PREPARATION. The soil should be thoroughly cultivated; ploughed or spaded 8 to 10 inches deep, well pulverized and thoroughly worked over, thus affording an opportunity for rapid expansion, and making an easy path for the tiny rootlets. To secure exceptional results, have your soil ploughed or spaded in the fall, or as early as practicable in the spring; then just before planting have soil thoroughly ploughed or spaded again.

FERTILIZER. Fertilization is one of the most important factors, to be successful with Dahlias. We all know that a growing plant, the Dahlia for instance, requires and takes from the soil certain properties; and in order to keep the soil in correct proportion, the materials the Dahlia takes from the soil must be restored. This must be done by fertilization. You can use dressing (either horse, cow, sheep or hen), or chemicals, or any commercial fertilizer rich in nitrogen, potash, and phosphoric acid. Fish and potash, acid phosphate in the form of bone flour, or sulphate of potash, are also very effective. My system of fertilizationevery other fall I give my land a top-dressing of stable manure, ploughing under and alternate with lime, using this as a top-dressing.

The manure restores the properties necessary, and makes the soil light and mellow, keeps it from being heavy and caking, while lime has the same tendency and keeps the soil sweet. When planting in the spring I use commercial fertilizers exclusively (a complete potato fertilizer and ground bonemeal in equal proportions). Every fourth or fifth year I make a fall planting of winter rye, then turn under in the spring, planting the bulbs with commercial fertilizers.

An application of manure (either in liquid or ordinary form), several times throughout the grow-

ing season proves very beneficial, furnishing new material for the growing plants and insuring you the very best results.

TIME OF PLANTING. The time for planting Dahlias varies according to the locality: whether your spot is sheltered or open, early or lateness of the season, and the times when the general crop of flower is desired. Dahlias can be planted any time after danger of frost is over, and under ordinary conditions will blossom in from 6 to 8 weeks after they have been planted. It is always best to wait until the ground becomes thoroughly warmed.

PLANTING. Plants bulb in hills or drills, laying flat down, 6 inches deep. Do not stand the bulb on end. If you stand the bulb on end, having the sprout near the top of the Iground, all the new

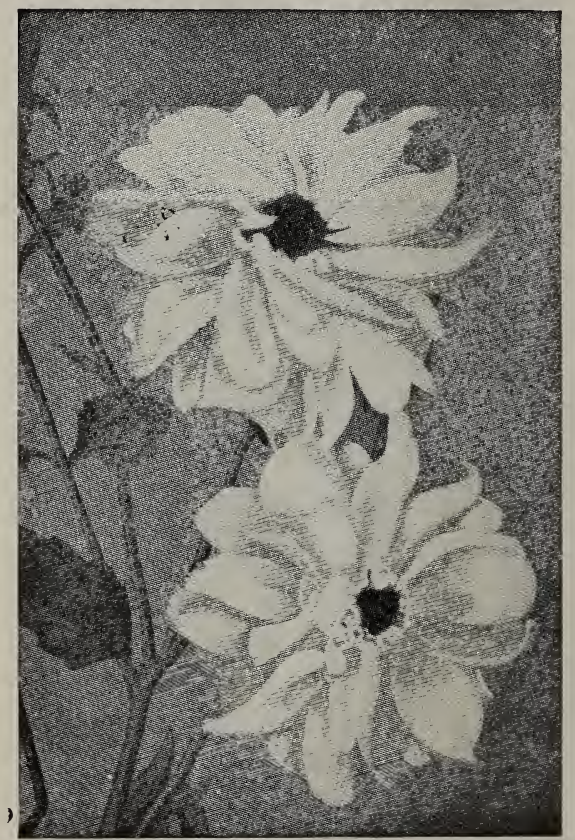

Queen Wilhelmina (See page 22). 

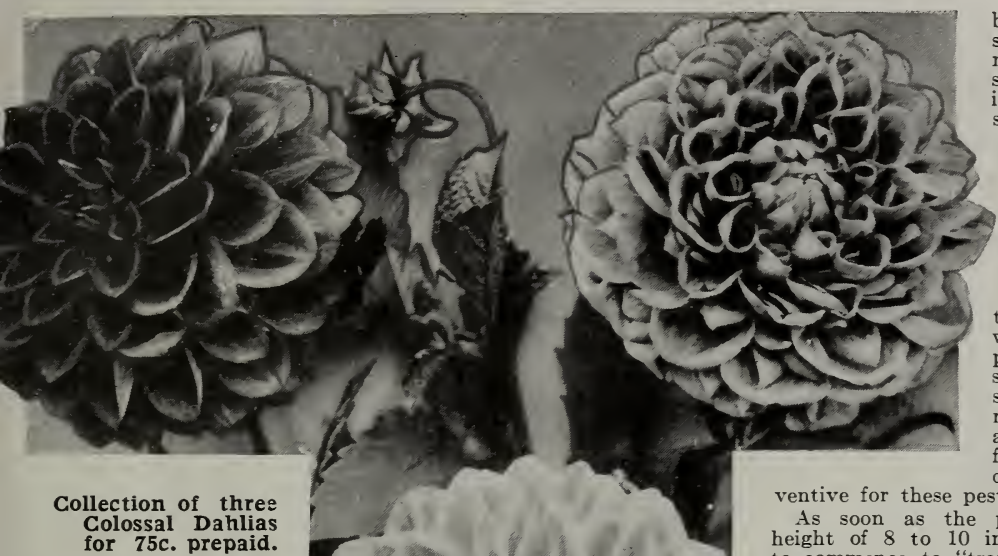
Colossal Dahlias
for $75 c$. prepaid.

R O S E, at the right. (See page

REGGIE, at the left. (See page 30).

Y E L O W COLOSSE, below. For description see page 30 .

bulbs which form will grow near the top of the ground and when you have a dry spell your plant becomes st un t ed, whereas, if the bulbs were planted flat down 6 inches deep, no matter how dry the season, the bulbs would re c e i ve sufficient moisture to keep them growing. If planting with manure cover manure an inch or so before planting bulbs: fertilizer should be thoroughly worked into the soil. Either fertilizer or manure will burn the sprout; be sure to cover with soil.

By planting the bulb first, then covering an inch or so with soil and applying your fertilizer or manure, your plant receives the entire benefit of the dressing. The dressing is above the bulb and every rain carries the food down to the roots, whereas, if your dressing is below the bulb, each rain takes your dressing further away from your plant.

Summary: Plant bulb 6 inches deep, flat down, having sprout or eye facing upward: cover with soil an inch or so, applying dressing, and cover in level.

CULTIVATION. Cultivation is the principal requirement of the Dahlia-the most important of all operations to insure success. Keep the soil well cultivated and free from weeds; never allow the soil to crust.

CARE OF PLANTS. Give thorough cultivation, deep at first and continued once a week until the plants commence to flower. After they commence to blossom do not cultivate, as then is the time the new roots are forming and you are apt to cut off the new tubers, weakening the growth of the plant. Do not fail to stir the soil after each rain, keeping the soil from forming a crust on the surface, or baking, and cons e r ving the moisture in the soil, thus avoiding the necessity of watering.

As the shoot or plant commences to show itself above the ground, care should be taken at this time for the prevention of $\mathrm{cut}$ worms and other pests that destroy the young shoots; I recommend vermine, aphol, cut-worm food or tobacco dust, as best preventive for these pests.

As soon as the plants attain a height of 8 to 10 inches it is time to commence to "train" your plants. There are three systems from which you must choose: The Staking System, the Branching Method and the Massing System.

The Staking System is the most popular, many amateurs finding it the most successful. Dahlias under this system should be planted from 2 to 4 feet apart according to the amount of space you have to devote-the larger, the more robust the plants. Stakes should be set when the Dahlia is planted. As soon as plants attain a height of 2 to 3 feet they should be secured to the stakes, thus protecting them and preventing the brittle stalks from being blown over or getting broken.

The Branching Method. This system is advocated by many professionals and does away with staking. Plant in hills or rows from 18 to 30 inches apart. When your plant has two sets of leaves, pinch off or cut out the whole top of the plant; at each leaf a branch will start, thus making four branches one at each leaf. Do not pinch off your plant more than once, as this system makes your plants two weeks later in flowering; but you receive four flower stalks, each of which will blossom equal to the one stalk which you would have received had you left your plants growing without pinching. When the plant is grown it will have a short, strong, single stalk, which comes only an inch or two above the ground, with four branches of flowering stalks. The plant is short and has a neat branching appearance; the branches are self-supporting and are not easily blown over by the winds.

The Massing System. This is the system I use in planting my immense fields-avoiding the extra labor and expense of staking, the woodeny effect of stakes in your garden and giving a solid mass of foliage and flowers, more beautiful and effective than where Nature's beauty is broken at each interval with a stake. Plant bulbs in rows from 10 inches to 2 feet apart, according to the amount of space you have to devote. The plants are self-supporting, each plant supporting and protecting the other.

At the height of 18 inches spray occasionally with arsenate of lead, nico-fume liquid, nicoticide tobakine, whale oil solution or other first-class solutions to kill and keep away the aphis or green fly, which often infest Dahlias.

Both wood ashes and lime are good at all times. and in addition to being good fertilizers, are effective as preventives against insect pests. 


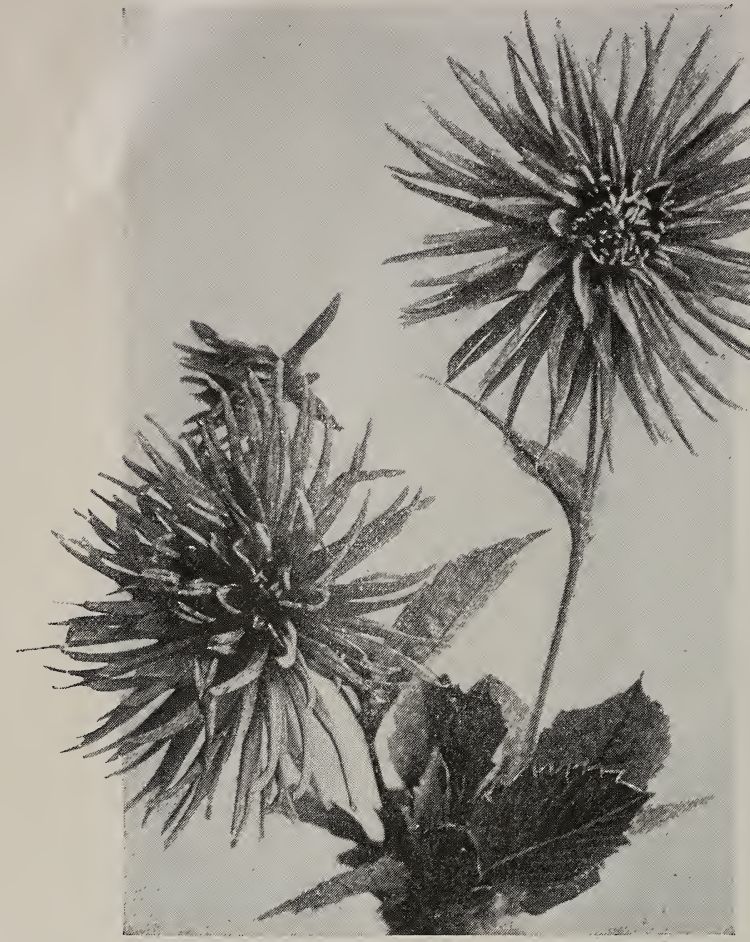

Alight, Cactus Dahlia (See description, page 12).

To obtain the largest and most perfect flowers, only the best and largest buds should be allowed to mature; the others being taken off, enabling the full strength to develop those into exhibition blooms.

DISBUDDING. Some varieties of Dahlias require thinning and disbudding to produce the best flowers. Varieties having an excessive amount of foliage and small growth should have a considerable part of their branches removed, while those having more buds than can be properly developed or matured should be disbudded. The operation in no way endangers the plants and anyone can do it. Thin and disbud if necessary, moderately or severely as conditions seem to require.

Taking a budded stalk or branch, you will note the large or first bud on the stalk, and also, that at each leaf all the way down the stalk new shoots or bud-stalks form; these in turn produce buds and flowering stalks, which over-top the first bud. The first bud on every stalk is always the largest and produces the largest and best flower, ordinarily. Before the first flower is in full blossom, the first two side shoots have formed buds and burst into flowers. These in turn become passe, to be replaced by flowering shoots from the set next below, or the second pair of side shoots.

On most varieties the first flower has a short, stiff stem; we disbud to lengthen the stem and to secure larger flowers.

The proper way to disbud: When the first bud is small the first set of side shoots should be removed with a sharp knife. This forces all the plant life that under ordinary conditions would have developed the first two side shoots, into the first bud, making the first flower much larger and giving it a good long stem. Removing the first set of shoots also forces ahead the second set and they in turn burst into flower.
As you cut and remove your flowers, your plant sends forth new flowering stalks from the bottom of the plant; the more flowers you cut, the more will grow.

Disbudding is more generally used for flowers for exhibition purposes. When wishing the largest flower possible, for exhibition purposes, you can disbud every side shoot down the entire length of your stalk, forcing all plant life into the one flower, thus growing one flower of gigantic size; this disbudding in addition to forcing with manure (taken up under forcing) insures you much greater success at exhibitions.

Anyone can grow Dahlias of exhibition quality if they will digest these remarks, study plant requirments and then act accordingly.

After your plant has been blossoming continually and flowers commence to grow smaller, then is the logical and proper time to fertilize. Apply any good fertilizer broadcast, or any kind of manure available, but it is better to make two moderate applications then too much at one time.

FORCING. To produce the finest flowers for exhibition purposes: Plant 3 to 5 feet apart, using a liberal amount of manure or fertilizer; cultivate frequently; apply fertilizer or manure, broadcast or liquid form, at each or every other hoeing, and disbud. Nitrate of soda proves very effective for forcing. Apply in liquid or crystal form when plants are in bud; make applications often, but do not use too much at a time. Nitrate of soda is very powerful and if too much is used it will burn up your plants or force them to such an over-growth that the roots will decay during the winter. Apply nitrate of soda in crystal form on top of the ground, or in liquid form, using one tablespoonful of nitrate of soda crystals to a gallon of water, using sprayer or watering can.

When the flower buds appear, only one bud should be allowed to come to maturity, enabling each branch to produce one exceptionally fine, perfect flower. The flowers, for quality, must not be allowed to receive the drenching rains or scalding sun when nearing full bloom and should be protected from such.

It is always advisable to cut flowers that are to be exhibited as late as possible at night when the dew is on them, placing them in water and keeping them as cool as possible over night, thereby enabling them to withstand handling, packing and transportation.

WATERING. Although I wish it understood that I do not believe in watering, and find from experience that it is unnecessary, a judicious watering of your plants proves very helpful. Watering plants in beds or various places, especially near trees, on lawns, along walks, etc., proves beneficial but when you water, do it thoroughly. It is that constant surface sprinkling every day that causes surface roots and soft growth, that I do not advise. A thorough soaking once or twice a week during a drought, with the soil stirred the following day, is an excellent thing where water and time is at hand.

However for commercial purposes we receive better results by not watering.

HARVESTING. The harvesting and packing for winter is very important, upon which depends your future success. Should you lose your Dahlias during the winter, you will be obliged to buy new ones in the spring; therefore, these suggestions are important.

Dahlias should be harvested shortly after their foliage has been killed by frost. I find from experience that as soon as the frost kills the foliage, the strength of the stalk recedes back into the bulbs. By digging two or three days after your plant has been killed by frost, your clumps are in a perfectly dormant condition, having no sprouts, keeping per- 
fectly all winter and sending forth sprouts in the spring, which is the proper time.

Dahlias may be dug with fork, spade or plow. In digging or harvesting the clumps great care should be taken. Dig them and dig very carefully; do not pull them up. You have large clusters of bulbs or clumps; each bulb has a neck, which is the small portion between the bulb and where it joins the stalk. The clumps should be dug or lifted carefully, so as not to break the necks of the bulbs. If you crack, girdle or break the necks sometimes they will dry up, other times decay. However, when the clumps are divided, the bulbs with broken necks are weak and not as good and it requires longer for the bulbs to become established before they commence to grow after they are planted in the ground. After removing the clumps, shake gently to remove the soil that would naturally fall off. Cut off tops within two or three inches above tops of clumps, allowing them to be exposed to the sun and air for only an hour or two. Do not allow them to stay out two or three days to dry up, then wonder why they are withered and fail to sprout. Pack in a cool, frost-proof place where extremes of temperature may be avoideda place having an average temperature of about 45 degrees. Do not cover or pack in any material or with any substance. Cork, sawdust, shavings, coal ashes, sand or earth, all hold and retain a dampness or moisture which is unnatural, making it too close, compact and damp, causing the clumps to start to mildew or decay. Would you pack your potatoes in any of the abore?. Simply pack clumps one on top of the other, placing each clump upside down. Undoubtedly you are aware that the Dahlia stalk is hollow and that this hollow contains a watery substance or acid. If you pack your clumps with the stalks up, the acid will flow back into the crown of the clumps, causing decay, where as, if you turn your clumps upside down the acid must flow out, and clumps will remain in a perfectly dormant condition. Pack clumps upside down in boxes or barrels, packing one on top of the other. Dahlias in an old-fashioned cellar will keep first-class without any covering; in a cellar having a cement bottom or heat, the boxes or barrels should be lined with heavy paper and covered with paper or burlap. Covering with paper or burlap excludes the air and preserves a more even temperature. In heated places the circulation of air and heat causes the bulbs to shrivel and dry up; a coverering of this kind prevents the roots from shriveling.

DIVISION OF GLUMPS. Although I divide clumps all winter, it is because of the number of clumps I have to divide; I recommend that the amateur wait until spring before dividing. Dahlias keep during the winter much better in clump form In the spring the clumps commence to send out sprouts, which aid in dividing properly. To divide, use a sharp knife. Separate, leaving each bulb separate, first dividing the clump in half, then dividing to one bulb. Plant only one bulb in a hill; never plant more than two bulbs. In dividing, great care should be taken and a portion of the crown or stalk should be left on each bulb. It is on the crown that the sprout starts, and if the bulb has no crown, it is worthless.

SIZE OF BULBS. The size of the bulb or tuber does not in any way designate the size or quality of the flower. Some varieties of Dahlias always produce very small bulbs, while other varieties make large ones. Do not consider small bulbs worthless, for they are equally as good and in many cases better than large ones. Medium and small sized bulbs more often produce the finest and highest colored flowers, and in many cases the best and most effective plants. The only requisite of a Dahlia bulb is: Be sure that your bulb has one or two eyes or sprouts, whether large or small, and with proper cultivation success is generally assured. A clump, root, bulb, or division of a clump, pot-root, cutting, sprout, and even a Dahlia seed, will grow and blossom, all equally well. It is not the size, but the care and cultivation-cultivation is the principal requirement of the Dahlia.

CONCLUSION. There are no set rules to follow invariably by all or even by any one grower year after year. In fact, each soil, location, climate or season, may call for different treatment. Study your plants; watch them as they develop; try all experiments along lines in harmony with nature's laws. Success with Dahlias is the same as with anything else; do everything in moderation; excess in any direction is unwise. In many locations conditions are so favorable that Dahlias grow to perfection with practically no attention. So it is with seasons-some years Dahlias do well the entire season, but there is no reason why Dahlias should not be grown successfully year after year. MIy methods of cultivation are simple and easily followed, the treatment and requirements are so simple, there is no reason why you should not be successful with your Dahlias. The Dahlia is one of the easiest plants to grow and will produce more flowers than any other plant in the garden, if proprely cared for.

\section{WILL WANT MORE FLOWERS LATER.}

\section{J. K. Alexander. Pittston, Pa., May 4th, 1918.}

Dear Sir:-I am pleased to tell you the box of bulbs arrived this A. M., and I found them to be in perfect condition and very nice bulbs. I notice you sent an extra Queen Emma, for which I wish to thank you. I shall want more flowers from you later. MRS. J. J. BRYDEN

36 Swallow St.

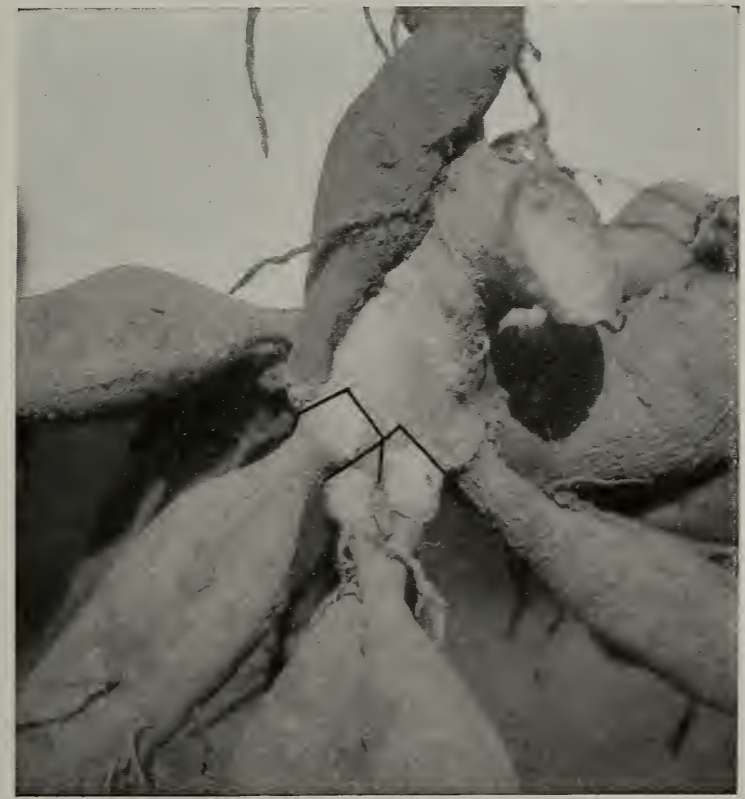

Dahlia Clump, Showing Proper Method of Dividing. 


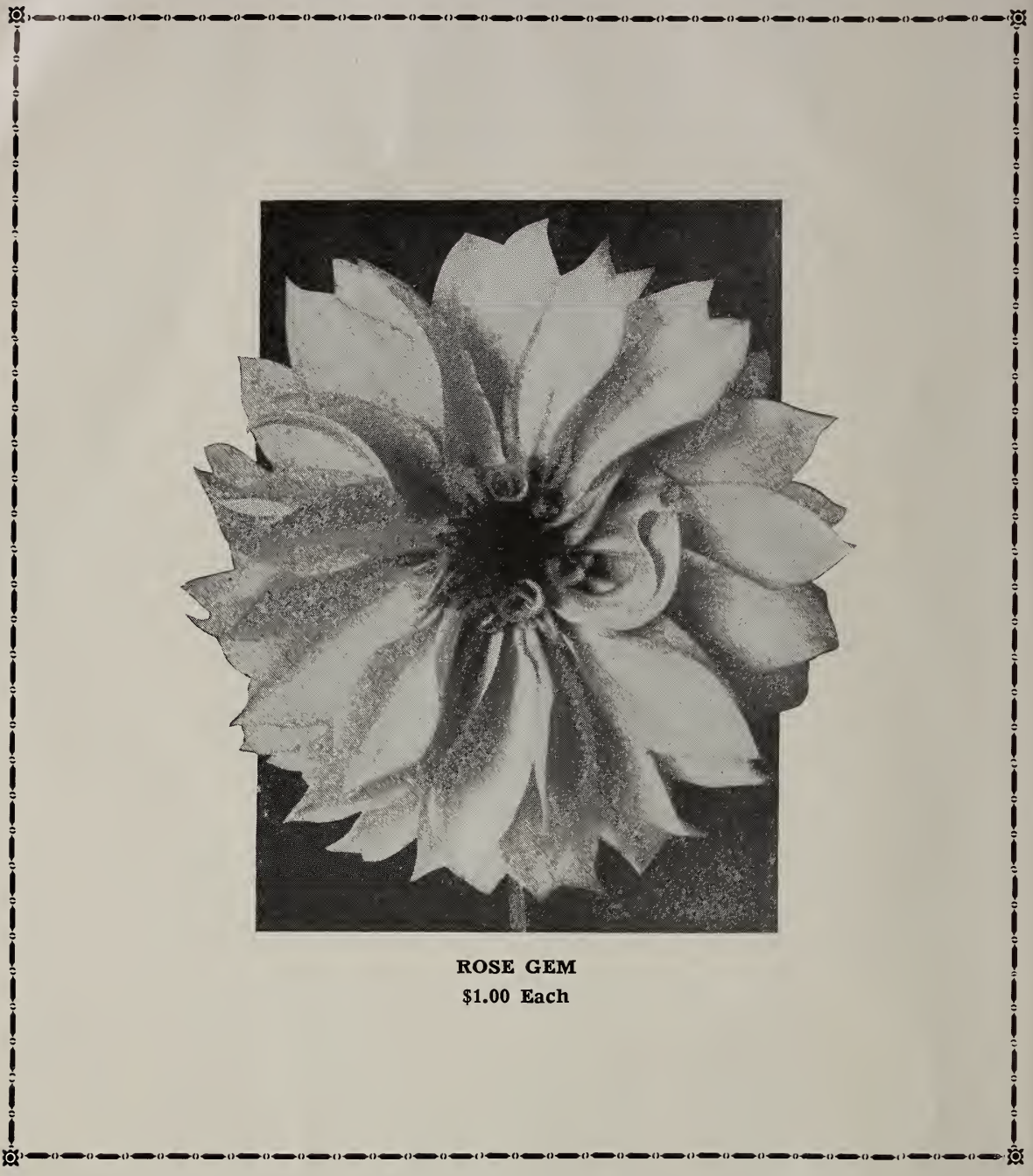

\section{Terms of Sale}

Cash With Orders. Remittances may be made by Post Office or Express Money Order, Bank Draft or Registered Letter at my risk. (Remittances for less than $\$ 5.00$ can be made in U. S. Stamps). All orders for bulbs will be shipped by Parcel Post, Express or Freight, whichever way we deem advisable, prepaid to all parts of the United States and Canada; unless otherwise stated. I guarantee their safe arrival in good condition. No extra charges for packing.

Any one variety priced at 15 cents may be had at $\$ 1.50$ per dozen.

Any one variety priced at 20 cents each may be had at $\$ 2.00$ per dozen.

Also the same with 25 cents, 35 cents, 50 cents, 75 cents and $\$ 1.00$ varieties.

Always address,

\section{J. K. ALEXANDER}




\section{Announcement}

I take great pleasure in announcing to my customers and friends that in 1917 I purchased the entire stock of Dahlias belonging to Mr. Edgar W. Ela of Woburn, Mass., who for years was known to the world as one of the most reliable up-to-date growers of this section. Mr. Ela grew about 5 acres each year, and always handled a fine class of Dahlias.

\section{How to Keep Cut Blooms of Dahlias}

Freshly cut flowers will keep considerably longer, and wilted flowers if not in too serious condition, will be entirely restored in appearance if the following suggestions are followed: Cut blossoms in early part of the day, whenever possible. Fill receptacle with water, as hot as can be borne by one's hand. Plunge the stems, but not the foliage, almost their entire length into the water; let them remain in the water until it cools, then transfer into cold water as in usual manner, with the addition of a quarterteaspoonful of salt to a quart of water. If the stems are particularly hardy and wiry, water near boiling point may be used to good adrantage. My subgestion would be, try it and be convinced, regulating depth of water to length of stems.

1114 Mass. Are., S. E.

Washington, D. C.. July 1, 1918 . My dear Mr. Alexander:

Allow me to express to you my keen appreciation for your kindness in having sent me the Dahlia "Alight." " My other Dahlias are just doing fine and I am immensely proud of them.

I remain, your respectfully,

(MRS.) DOROTHY POWERS.

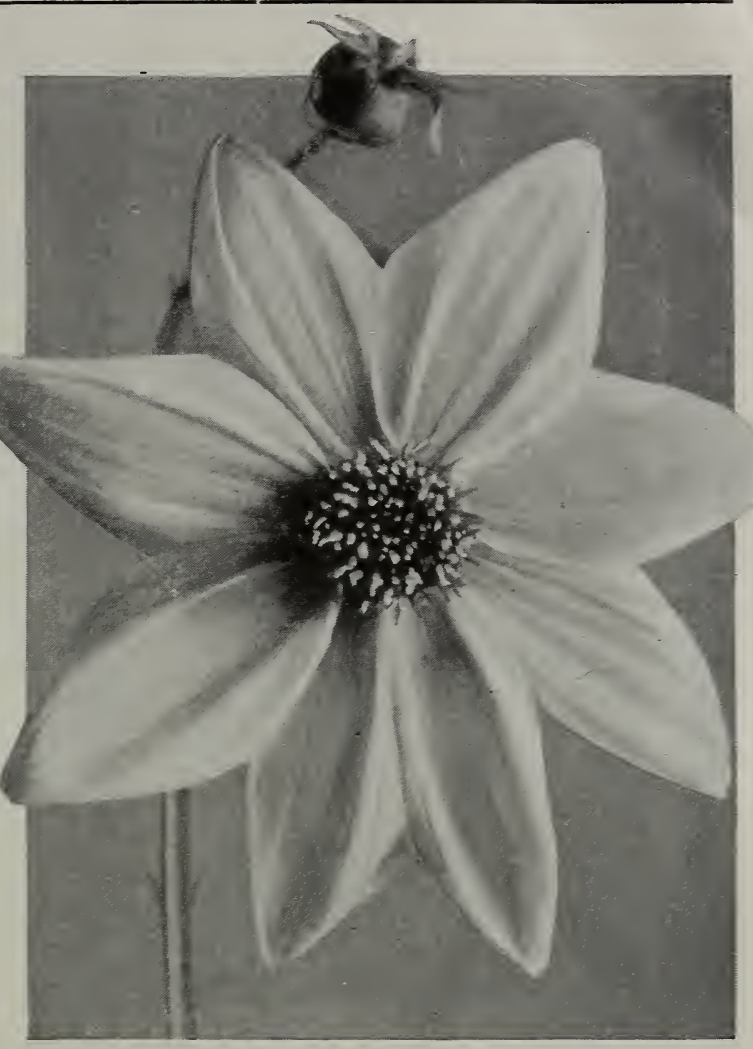

Blanche-Single Dahlia (See page 36).

\section{Classification of Dahlias}

Dahlias are divided into two divisions, double and single; and each division is again sub-divided into classes, according to size, form of flowers and arrangement of colors.

DOUBLE DAHLIAS are divided into the following classes: Cactus, Decorative, Peony-Flowered, Colossal, Show, Faney and Pompon.

CACTUS DAHLIAS. This class is of comparatively recent introduction, and is entirely distinct from any other class. The flowers are loosely and artistically formed, and very irregular, resembling the Chrysanthemum. Petals long, twisted and terminating in a point. Some varieties possess nearly straight petals, others are gracefully incurved.

COLLARETTE DAHLIAS. The flowers are single, with an additional row of shorter petals around the disc, which forms a frill or collar, usually of a different color from the outer petals.

COLOSSAL DAHLIAS. Those producing flowers of gigantic size, great depth, massive in proportions, and globular in shape; petals are cup-shaped, and placed in exact regularity. Plants are strong, sturdy and robust.

DECORATIVE DAHLIAS are large, flat and full to the center; petals quite irregularly situated, long, broad, flat and nearly straight.
PEONY-FLOWERED DAHLIAS. A new type of Dahlia; flowers are semi-double, having two, three, or more rows of broad, flat, loosely arranged petals, surrounding a conspicuous, rich, golden yellow center. Petals are often pointed and sometimes twisted, and in some varieties the inner row of petals twists and curls over the center, giving the appearance of a Japanese Peony, hence its name. The blossoms are very effective and graceful, and adapt themselves to bouquets better than any other type; some are very large and fluffy.

FANCY DAHLIAS. In form and habit identical with the Show Dahlia, but different in arrangement of colors. The flowers are tipped or edged lighter than the ground color, or splashed, striped, mottled and variegated, in every conceivable manner. They often throw a solid flower, on the same plant.

POMPON DAHLIAS. In form identical with the Show and Faney, the only difference being size of flowers: they are small, round, miniature Dahlias, and flower much more freely than any other class.

SINGLE DAHLIAS. These have but one row of petals, generally eight, resembling the Cosmos, and are very free-flowering.

SHOW DAHLIAS. These are large, spherical, regular, compact and full to the center. The flowers are either solid, edged, tipped or shaded darker. 


\section{Cactus Dahlias}

The greatest and most phenomenal type of all Dahlias, showing the most remarkable development and being far superior to the other classes. My collection of Cactus Dahlias is the finest and most up-to-date in existence; the result of a careful selection of the introductions of every Dahlia specialist and hybridizer, in reality the very cream of the Cactus Dahlia world. We import Dahlias from all over the world, testing in our trial grounds several thousand. The following varieties have withstood our ordeals, as to quality, ability to flower and general perfection.

Sincerely believing the time has come when there should be a distinction between the different types of Cactus Dahlia, I take this opportunity to divide the Cactus Dahlia into three classes; The Incurved Cactus, the Straight-petaled Cactus, and the Hybrid Cactus. The fact that the term Cactus Dahlia is deceiving, leads me to make this distinction. It

is so general, and the shape so different, that I think it best to make a more definite division. In the exhibition hall, the Cactus Dahlia is the cause of considerable discussion. We claim we should distinguish the modern incurved and tightly quilled Cactus, that is of higher quality and not in the same class, from the broad, flat-petaled Hybrid Cactus. In judging, the type should be considered, and where they are all classed as Cactus Dahlias they are upon the same equality, while in reality they are far from it. With the following divisions there is sufficient distinction to warrant classification and exhibiting of each variety in its individual class.

The Incurved Cactus Dahlia, with quilled and incurved petals or florets; the Straight-petaled Cactus Dahlia, with quilled, straight petals; the Hybrid Cactus Dahlia, with broad, straight, slightly quilled and pointed petals.

\section{Phenomenal New Cactus Dahlias for 1920}

The seven new Cactus Dahlias listed below I offer as being absolutely unequalled for coloring, size and general. habit.

I will send these seven New Introductions prepaid for $\$ 18.00$.

ALICE B. RAND. Alexander's New Incurved Cactus Seedling. An exquisite shade of rose, much deeper than Tyrian rose, passing to a deeper shade at the tips. The flowers are perfectly formed and of moderately incurved shape. The plants are of good height and produce their blooms on long, wiry stems. This new creation received an Honorable Mention at the September, 1919 exhibition of the Massachusetts Horticultural Society at Boston, Mass.
$\$ 3.00$ each.

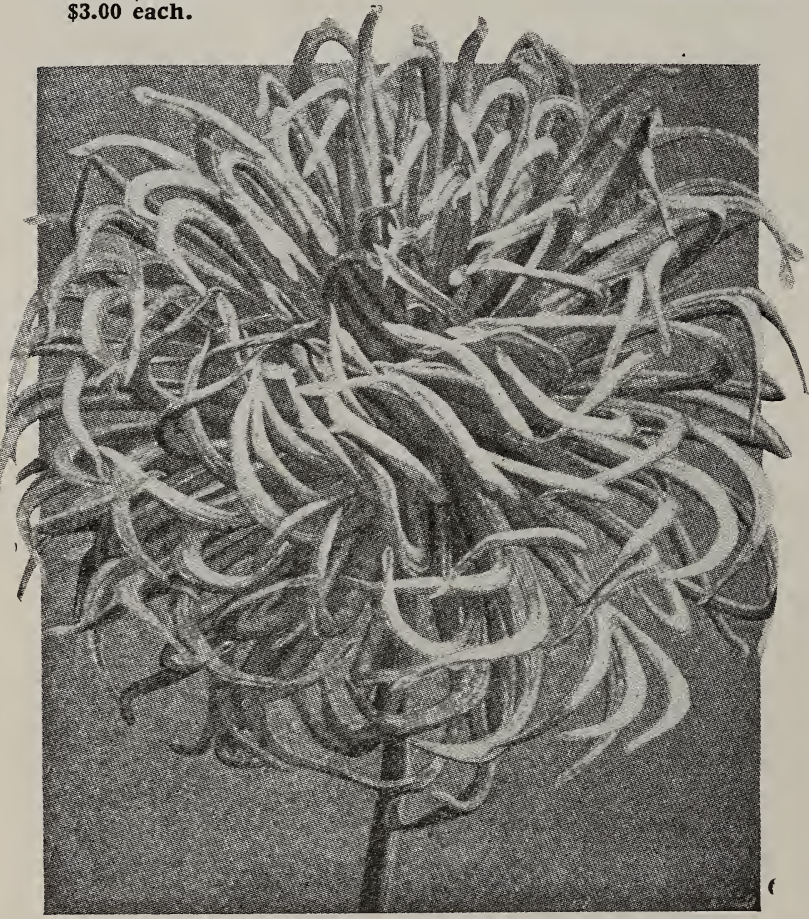

BECKET. A valuable addition to the Cactus class The plants are tall and sturdy with exceptionally good flower stems and produce the blooms freely. The color is a delicate shade between deep, mallow purple and clear rose blending to white at the center. The flowers are large with long, slender petals slightly incurved. A fine flower for either garden or exhibition. \$1.00 each.

BERTRAM S. VARIAN. New 1920 Cactus Seedling. Named for and with the permission of Mr. Bertram S. Varian of Weiser, Idaho. A very brilliant, deep scarlet of the moderately incurved form, of good size on long stems. This is one of the freest flowering Dahlias in my new list, and this fact combined with its brilliant coloring will make it especially conspicuous and attractive in any garden. $\$ 3.00$ each.

CYGNET. A beautiful lemon-yellow at center gradually shading off to a paler shade of the same color exquisitely striped and splashed bright scarlet-red. This variety is one of the very finest Cactus Dahlias. The stems are long and stiff and carry the blooms well above the foliage. The flowers are of large size and the petals are tightly quilled and gracefully incurving. \$2.00 each.

JOSEPH SPRY. New 1920 Cactus Seedling. Named after and with the permission of Mr. Joseph Spry of Boston, Mass., in appreciation of his courtesy and efficiency at the many exhibitions of the Massachusetts Horticultural Society.

One of the largest and finest of the New Cactus dahlias. The florets are very tightly quilled and long, being almost straight until nearing the tips when they moderately incurve. The color is a beautiful, deep chrome-yellow gradually passing to apricot-yellow and blending to strawberry-pink at the tips. A variety that belongs in the first rank as an exhibition flower. $\$ 5.00$ each. 
VICAR OF WASPERTON. Gigantic New Incurved Cactus Dahlia. According to Ridgway's color chart there are three shades of pink in this exquisite flower. The base of the petals is a beautiful alizarine pink with an overlay of yellow, blending to a shade of rosolane pink and edging off to a delicate cameo pink. The center of the flower is a charming primrose yellow. This new creation is one of the best of the English importations, having gigantic size and being ideal for exhibition purposes. The florets are very long, tightly quilled and beautifully incurved. $\$ 5.00$ each.

WILLARD E. GARDE. New 1920 Cactus Seedling. Named for and with the permission of Mr. Willard E. Garde of Sturgeon Bay, Wis.

The color is one of the clearest pink shades I have ever seen; a beautiful, life rose-pink changing slightly lighter in the center. The plants are of good habit and free flowering. This variety is well worthy of a place in any garden. $\$ 2.00$ each.

\section{Up-to-Date Cactus Dahlias for 1920}

These fifty recent introductions I will send prepaid for $\$ 50.00$. They are among the best samples of the Cactus Dahlia to date.

ABUNDANCE. This variety is exceedingly prolific -a fact which suggested the name. It grows ito a height of 5 feet, with blooms of medium size. The color is cerise at the base to deep pink at tips. $\$ 1.00$ each.

ATTRACTION. Large, elegant, full flower, of a clear, lilac-rose. The habit is perfect, with long strong stems holding the bloom stiff and upright. A very attractive variety. 75 cents each.

AVALANCHE. A gorgeous, glistening, pure white, of the same type as Kalif. The flowers are large size, and are produced on long, stiff stems, well above the foliage. The best white of its type. 50 cents each.

BIANCA (Hybrid). (See illustration, page 12). A new Cactus Dahlia of large size and splendid form. Coloring is beautiful rose-lilac with white shadings and bloom is held perfectly erect on strong, stiff stems. Free-flowering. \$1.00 each.

BOWEN TUFTS. Alexander's New 1918 Incurved Cactus Dahlia. The flowers are of gigantic size, being a bright capucine orange blending to a bright golden orange in the center with yellow reflex. Very stately, good stems. $\$ 5.00$ each.

CONSTANCE. A very attractive, rich, rosy pink. The flower is large, very full and deep, fine center, long petals, moderately and regularly incurved. The plants are strong and with erect habit. $\$ 2.00$ each.

CLINCHER. Up-to-date Incurved English Cactus Dahlia. As the name denotes, giving a clinching appearance, the florets or petals being gracefully and effectively incurved and so perfect as to almost meet at the center. A gigantic Cactus, producing its enormous blossoms with great ease, but on pendent stems. The color of this variety is most pleasing, being a beautiful shade of heliotrope. 75 cents each.

CURLEW. A distinct and pleasing old-rose color with very long florets incurving over the center. The splendid size and shape of the flowers, erect growth and strong stems of the plants make this variety one of the most desirable to date. \$2.00 each.

EDITH CARTER. A variety of great beauty and one of the finest for exhibition purposes. Color, yellow, heavily tipped bright rosy carmine. Erect habit. 75 cents each.

E. F. HAWES. A new garden Cactus Dahlia of great value. Flowers are borne upon stiff, wiry stems, well above the foliage. The color is an exquisite clear salmon-pink shade, which, combined with its excellent habit, places it in the front rank of the "all-round" Cactus Dahlias. \$1.00 each.

FAIRY. New Incurved Cactus Dahlia. The plants are dwarf, producing blooms freely; petals are long and gracefully incurved. Color a beautiful ivory-white. $\$ 1.00$ each.
F. W. FELLOWS. This variety produces huge flowers in profusion. The petals are narrow, straight and very numerous, allowing the blooms to remain full until long past their prime. The growth and habit is all that could be desired. Color a bright orange-scarlet throughout. $\$ 1.00$ each.

GEORGE WALTERS. This is the most wonderful Dahlia ever offered. It is a Hybrid Cactus of exquisite coloring, being a bright salmon-pink, artistically suffused with old gold. It is the largest Hybrid Cactus ever introduced. The flowers are borne on long, stiff, wiry stems, well above the foliage. It won a gold medal for best single flower in one of the largest shows in 1917. \$2.00 each.

GENERAL SMITH-DORRIEN. A New Incurved English Cactus Dahlia of a fiery scarlet color, and of the finest quality. A beauty in every way. $\$ 2.00$ each.

GOLDEN EAGLE. New Incurved English Cactus Dahlia. Orange-yellow, suffused rose, and fawn. Flowers are produced 'on long, stiff stems in great profusion. Moderately incurved. 75 cents each.

H. H. THOMAS. New Up-to-date Incurved English Cactus Dahlia. Few varieties combine so many good qualities. The flowers are of beautiful formation, having long, incurving florets or petals. The habit of the plant is excellent; a free-flowering variety, possessing long, straight stems and producing its flowers well above the foliage. The color is a beautiful rich deep crimson. 75 cents each. 


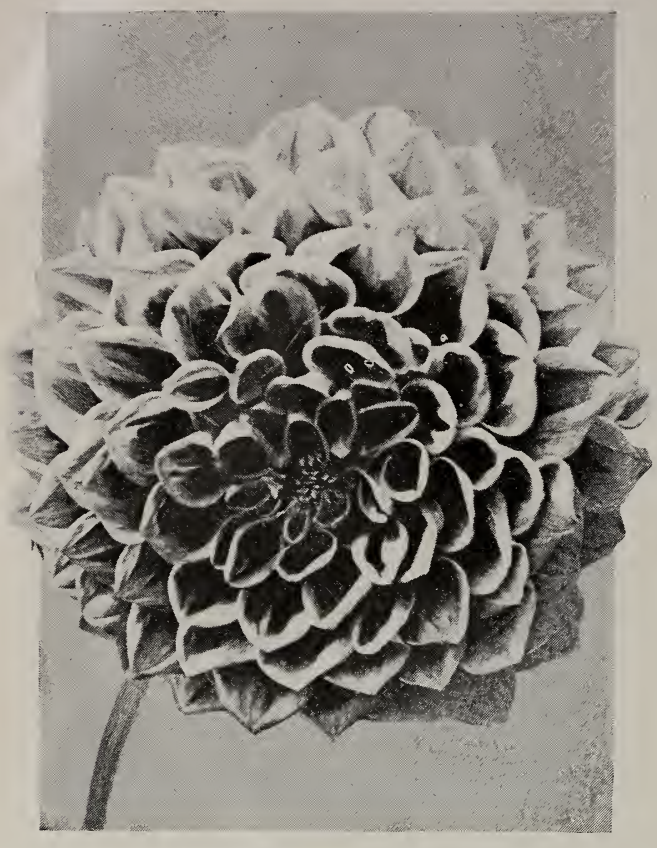

J. K. Alexander. (See page 30.)

\section{CACTUSIDAHLIAS-Continued.}

HONESTY. A very free flowering variety of perfect habit. The flowers are white at first, changing with age to pale pink with white center. Each are produced upon stiff, wiry stems, well above the foliage. \$1.00 each.

HON. MRS. GREVILLE. The plants of this variety are particularly sturdy, producing their blooms freely. Orange-yellow and salmon. \$1.00 each.

IGNEA. Bright crimson-scarlet. A very large and distinct variety. Perfect form. $\$ 1.00$ each.

J. HERBERT ALEXANDER. Wonderful New Incurved Cactus Seedling. We can rightly term this a model Dahlia. After thoroughly testing this new Dahlia, and finding it one of the most satisfactory varieties in existence, I deem it worthy of bearing the name of my son. The plants have an upright, pleasing style of growth, being very strong and sturdy, and producing their blossoms upon long, perfect stems, well above the foliage. The flowers are of gigantic size, the first flower this last season being almost eight inches in diameter, and continuing to produce good-sized flowers throughout the entire season. The flowers are produced with exceptional freedom, the plants being literally covered with flowers from July until frost, which makes it a magnificent garden variety. The coloring of this Dahlia is remarkable, the center of the flower being a charming shade of golden yellow, exquisitely blending to sweetest deep salmon-pink. In form it is all that can be desired, having very long, narrow, tightly quilled florets, which are very prettily incurved. This will prove to be one of the best all-round Cactus Dahlias in existence. $\$ 5.00$ each.

KALIF. A truly majestic flower, frequently measuring over nine inches in diameter. The flower is of perfect Hybrid Cactus form, and in color a beautiful pure glowing scarlet. The habit of the plant is all that can be desired, growing, with us, about four and one-half feet in height. The gigantic flowers, which are produced freely, lare held erect on strong ${ }^{2}$ stems of wiry stiffness, making it a most effective and useful variety for cutting, as well as for garden decoration. "Kalif" is the first variety that has had the distinction of receiving the National German Dahlia Societies' highest award. This variety bears myhighest recommendation. 75 cents each.

LAPWING. Exceptionally large blooms of the finest quality. Color, orange, shaded red. One of the very best. $\$ 1.00$ each.

LAVINIA. Coppery-red to madder-crimson. Very large, distinct form; florets spirally twisted. Free bloomer. \$1.00 each.

LORNA DOONE. This exquisite medium sized Cactus is especially suitable for garden decoration and cutting. The blending of colors is unusual; yellow at base, the greater part of the floret being a beautiful pink shade, yet so decidedly tinged with carmine as to make it very distinct. 50 cents each.

MILTON HOWARD. A charming shade of bright pink, with white at center and tips of petals. \$1.00 each.

MRS. BRANDT. Magnificent New Cactus Dahlia. The flowers are large, charmingly beautiful, and perfect for exhibition purposes. The florets are exceptionally long, and very evenly distributed, standing out like a circular array of spears, while the center is a picture of perfection. The plant makes splendid specimens, with deep green foliage, and carry their flowers on enormous stems, well above the foliage. The coloring is most exquisite; a beautiful salmon-buff, blending to golden yellow at center. One of the largest and best, $\$ \mathbf{\$ 1 . 0 0}$ each.

MRS. C. COOPER. One of the largest Cactus Dahlias yet produced. The petals are long and very narrow, slightly incurved. The color is a charming cream-suffused salmon. $\$ 1.00$ each.

MRS. C. H. BRECK. A new Cactus Dahlia of exceptional merit. Color, creamy yellow passing to various shades of rose pink. 50 cents each.

MRS. FERDINAND JEFFRIES. A rich, velvety maroon of the Hybrid type. The petals are broad, curled and twisted. A very free bloomer, large and massive. $\$ 1.00$ each.

MRS. EDWATD DRUREY. New Incurved English Cactus Dahlia. This creation will prove a thoroughly reliable variety in any situation. Color is a delicate shade of purple-crimson. The flowers are formed evenly, but not strikingly incurved. Large blossoms produced very freely, and are good throughout the season. \$2.00 each.

MRS. HENRY RANDLE. New Incurved English Cactus Dahlia. We can rightly term this a model Dahlia. The coloring is one of the sweetest possible, being pale cream at center, quickly changing to a lovely rose tint and distinctly tipped creamy white. The florets are tightly quilled and very gracefully incurved. The plant is exceptionally healthy, having an upright and pleasing style of growth. $\$ 1.00$ each.

MRS. WARNAAR. New Holland Cactus Dahlia. A "Garden Cactus" of superior quality; herA ded from Holland, and recommended as one of the finest cut-flower varieties in existence. This most fascinating variety appeals to every flower-lover as a true sensation. The coloring is exquisite, being a delightful creamy white, overlaid and blending to a charming shade of pink. The flowers are produced upon long, stiff stems, well above the foliage; the habit of the plant being most pleasing. A blossom of gigantic size, and great merit. "Mrs. Warnaar" was first exhibited in Holland in 1914, where it received an Award of Merit at Haarlem given by the Dutch Bulb growers' Society, and an Award of Merit at Amsterdam, given by the Netherland Society of Horticulture. $\$ 1.00$ each. 
NANCY MAE. One of the best dark Cactus Dahlias grown. A rich, dark, cardinal-red, of extra large size for this type, it is held erect and stiff on long stems. 50 cents each.

NANTWICH. New Incurved English Cactus Dahlia. With this variety the habit is a great feature as well as the flower, the growth being upright and the flower stem particularly strong. The blossoms are of incurved form, the florets being evenly placed and unusually good in texture. The color is a beautiful golden orange, somewhat deeper in the center. 50 cents each.

NATALIE ALSOP. Alexander's New Cactus Seedling. Named expressly for and by special permission of Miss Natalie Alsop, in recognition of her great love for beautiful flowers. This new variety is a wonderfully pleasing creation, possessing all the good qualifications of the Dahlia. The flowers are most beautiful-a lively deep rose-pink, daintily blending to snow-white at the center. One of the greatest charms is the manner in which it carries its flowers; they being produced on very graceful, wiry stems. Plants are robust and sturdy, growing to an average height of 4 feet. \$2.00 each.

NIBULENGENHORT. Another gigantic flower of great value, both for exhibition and garden purposes. In color, a very beautiful shade of old rose, with a blending of salmon-pink and golden apricot. The flowers often measure eight inches in diameter. 50 cents each.

RED ADMIRAL. One of the best varieties for exhibition purposes, the blooms being large splendidly formed and freely produced. Color. bright scarlet. $\$ 1.00$ each.

REFEREE. A clear, bright, yet soft terra cotta The flowers are very large and produce freely Much admired by all wherever exhibited. $\$ 1.00$

RHEIMS. The color is a delicate salmon-pink with yellow base, shading off to pale yellow tips. A magnificent flower for either garden or exhibition. 50 cents each.

RICHARD BOX. New Incurved English Cactus Dahlia. A clear, light soft shade of yellow. This variety blossoms early and maintains a steady average of fine flowers throughout the season. Moderately incurved. 75 cents each.

ROSE QUEEN. Fine specimen of the incurving form with good stems. The color is a bright lilacrose. A very fine variety: $\$ 1.00$ each.

SCORPION. Wonderful New Incurved English Cactus Dahlia. One of the most sensational of the Incurved Cactus Dahlias. A flower of absolutely unique formation, the florets being very narrow and so gracefully and effectively incurved, twisted and interlaced as to almost meet in the center. At first sight one would think it was a Chrysanthemum. The blossoms are of medium size and of a beautiful clear yellow color. This variety is a great farorite with specialists abroad. especially appealing to the lovers of irregularly formed Cactus Dahlias. 50 cents each.

STABILITY. This new Garden Cactus Dahlia can be recommended as one of the finest. The flowers are produced upon strong, wiry stems, well above the foliage. The petals are long and straight, making a perfect flower. In color, most beautiful rose-pink imaginable. 50 cents each.

SYLVIA. New Incurved English Cactus Dahlia. Beautiful deep pink, blending to pale lemon at the center. Petals long and slightly incurver. $\$ 1.50$ each.

THE SWAN. One of the finest allround pure white Cactus Dahlias to date. Strong, sturdy grower. $\$ 1.00$ each.

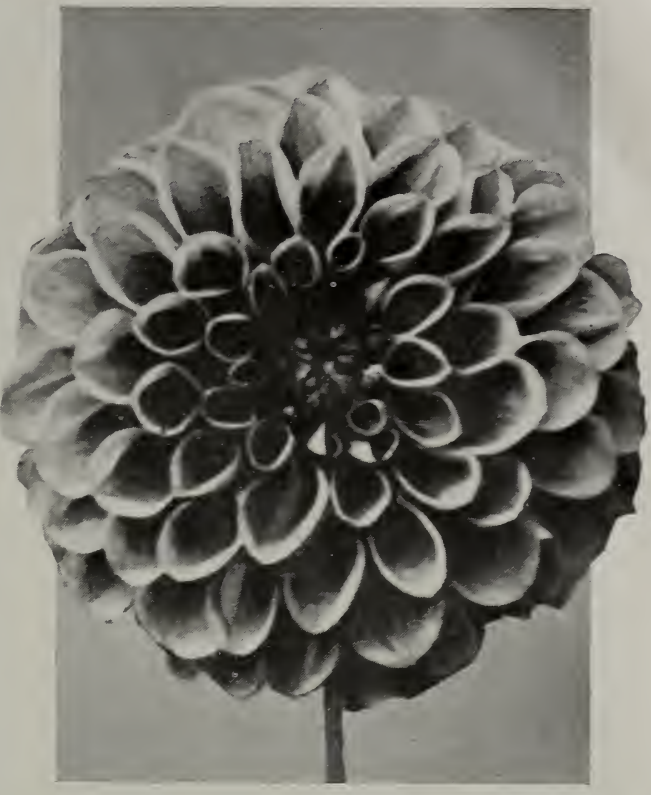

STRADELLA.

THE LANCER. An English variety, slightly incurved, of a beautiful, rich, scarlet red color. A flower of large size and good depth. $\$ 1.00$ each.

TOM LUNDY. An introduction from California and one of the largest Hybrid Cactus Dahlias grown. Of a dark velvety red, the blooms are held on long, stiff stems. A sensational novelty. Price, $\$ 3.00$ each.

THE IMP. Up-to-date Incurved English Cactus Dahlia. This monderful introduction is best described as "The Black Dahlia," the color being as near black as we have ever seen in Cactus Dahlias; a beautifully formed flower with long. clawlike petals and exceptionally good incurved form. The flowers are large, wonderfully gorgeous, and so dark that they have gained the name, "The Black Dahlia." This variety is one of the best in every respect, the plants being splendid, robust grower and remarkably free-flowering. 50 cents each.

URANUS. New Incurved English Cactus Dahlia. (See illustration on page 8). A very large blossom of exceedingly good form. In offering this variety we wish to state definitely that the habit is absolutely pendent. At the same time it is a most beautiful exhibition flower of finest incurved form and is destined to become one of the most popular. The quantity of blossoms produced is surprising. "Uranus" is a fancy Cactus Dahlia. the ground color being creamy white, thickly speckled and striped rosy-pink to vermilion-scarlet. One of the finest fancy varieties of the incurved type. A beautiful specimen. $\$ 1.00$ each.

YELLOW KING. Another gigantic Hybrid Cactus, splendid for cutting. A fine, pure vellow, passing to a lighter shade at the tips. The stems are long, stiff and upstanding. The plant is a vigorous grower and an early, prolific bloomer. $\$ 1.00$ each. A splendid introduction. 


\section{General List of Superb Cactus Dahlias}

This collection of 111 Cactus Dahlias prepaid for $\$ 30.00$.

(The three types of Cactus Dahlias are designated by the words: Straight, Incurved and Hybrid, after the name).

ALIGHT. (Incurved). (See illustration on page 4). Gigantic flowers of a beautiful orange-scarlet color. Petals very long and exceedingly narrow. This variety can be highly recommended as a desirable form. 25 cents each.

AMBASSADOR (Straight). Pure white. A flower of the finest quality. Long, stiff stems. 20 cents each.

AMAZON. A beautiful purple-violet. 25 cents each.

AURORA (Straight). Orange-yellow, heavily overlaid soft pink, occasionally tipped with white. 25 cents each.

AUTUMN GLORY (Hybrid). A beautiful brilliant orange-yellow. Flowers large. 50 cents each.

BEDINIA (Hybrid). Clear, bright orange, striped and flaked red; very striking. 25 cents each.

BILLIE BURKE. Cream, finely speckled and striped with purple. 50 cents each.

BORNEMANN'S LIEBLING (Straight). Very delicate, soft rose-pink. Extra fine. 20 cents each.

BRIGADIER (Incurved). Bright crimson, base and outer petals scarlet-crimson; petals long, numerous and beautifully incurved; large flowers. 50 cents each.

CANDEUR (Straight). A pure white variety and one of the best. 25 cents.

\section{SPECIAL OFFER}

Six Choice Incurved Cactus Dahlias, six discolors; my selection, for $\$ 2.00$, prepaid.

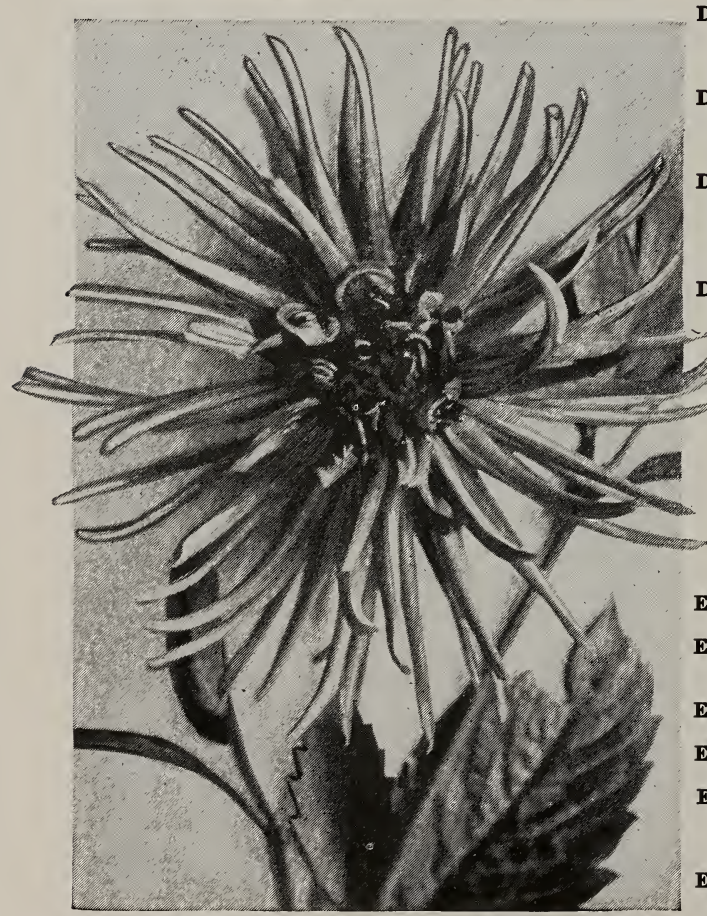

Clara G. Stredwick-Straight-petaled Cactus Dahlia.
CAPSTAIN (Hybrid). Soft red, tinted apricot. 20 cents each.

CHAS. H. CURTIS (Incurved). Rich, scarletcrimson; large, full. 50 cents each.

CHRYSANTHEMITE ALBERT DELAUX ( $\mathrm{Hy}$ brid). An enormous flower of vivid crimson. Plants of perfect habit, producing flowers in great abundance on stiff, wiry stems; especially good for cut-flower purposes. 35 cents each.

CLARA G. STREDWICK (Straight). (See illustration, this page). Clear, bright salmon, shaded yellow at base of petals. Large flowers with long, slim, twisted petals. Free flowering. 25 cents each.

COLUMBIA (Straight). Vermilion, tipped and striped with white. Long, narrow, star-like petals. The plants make very little foliage. 25 cents each. COMET (Incurved). A fancy Cactus of great originality. The coloring is quite distinctive, being a soft, lavender-pink, penciled and dotted a deep crimson. The plants make a high growth, with long, stiff stems. 50 cents each.

COUNTESS OF LONSDALE (Hybrid). Deep salmon-red. One of the best. Very free. Should be in every garden. 25 cents each.

COUNTESS OF MALMESBURY (Straight). Delicate peach-color pink, daintily blending to white at the center. Petals straight, very narrow and tightly quilled, completing a perfect star-shaped flower, 25 cents each.

CREPUSCULE (Straight). A gigantic flower; pale orange-yellow at center, exquisitely deepening to beautiful deep amber buff at outer petals. 35 cents each.

CRYSTAL (Incurved). White in center, pass-

th ing to deep silvery pink. Dwarf plants. Flowers abundantly. 75 cents each.

DAINTY (Straight). The blending of colors is superb, lemon-yellow at center daintily tipped sweetest rose-pink. Petals are very long and beautifully quilled. 25 cents each.

DEBUTANTE (Incurved). The coloring is most beautiful, being a very light tint of soft pink at the base, the upper portion of floret is white. 25 cents each.

DOCTEUR MENE (Hybrid). (See illustration page 18). Very free flowering, of great vigor; flowers are carried far above the foliage. Color, salmon-amber, shading to sulphur-yellow in the center. 25 cents each.

DUCHESS OF' MARLBOROUGH. Delicate silvery pink. Fine for garden decoration. 50 cents each. EARL OF' PEMBROKE (Hybrid). Bright plum color; large, bold flower. 20 cents each.

EDWARD D́RUREY (Incurved). (See illustration, this page). Many flowers are a delicate shade of yellow, tipped white; others are clear yellow, Moderately incurved. 25 cents each.

EFFECTIVE (Straight). A very distinct primrose, shaded amber. 25 cents each.

ELECTRIC (Incurved). A strong, vigorous grower and a very delicate charming variety. The color is clear canary yellow heavily tipped white. 50 cents each.

ELLA KRAMER (Straight). Rose-pink with much brighter center; fine form. 25 cents each.

EL YSIAN (Straight). Flowers large and perfect. Color, a bright lilac-pink. Very similar to "Rosa Starr" in color and shape. 50 cents each.

ETHEL (Straight). Pleasing shade of sulphuryellow. 20 cents each.

ETNA (Hybrid). Lilac, veined violet. Very attractive. Large. 20 cents each.

ETRURIA (Incurved). An exceptionally freeflowering early blossoming variety. A pleasing reddish apricot shade. Moderately incurved. 35 cents each.

EUREKA (Straight). This variety has all the good qualities of the Dahlia, being properly named. Color, very deep purple. Petals are long, straight and tightly quilled. 25 cents each. 


\section{Special Collection of Superb French Dahlias}

This collection of famous French Cactus varieties attracted much attention in our fields the past summer. Not only are the flowers of large size, but they have distinct and unique form. The habit of the plants is also very vigorous, and the profusion of perfect flowers is certainly remarkable.

I offer this wonderful collection of Five Up-todate Varieties for $\$ 2.00$, prepaid to any part of North America.

HENRI CA YEUX. Color, an old gold shading to golden yellow.

MME. HENRI CAYEUX (See illustration on page 17). A beautiful rich pink, daintily tipped with white.

REINE CAYEUX. A beautiful ruby-crimson.

CHR YSANTHEMISTE ALBERT DELAUX. An enormous flower of vivid crimson.

MLLE. GALY MIQUEL. Color a beautiful clear white, daintily marbled a pleasing rose-violet.

\section{GENERAL LIST OF CACTUS DAHLIAS-} Continued.

F. H. CHAPMAN (Straight). A gigantic reddishorange Cactus Dahlia of exceptionally fine form. The petals are exceedingly long, narrow and tightly quilled. The plants have a pleasing upright style of growth, 25 cents each.

FIREWORKS (Incurved). One of the finest of the fancy Cactus, being large, with good stems. Color a clear, deep yellow, streaked and dotted crimson. 50 cents each.

FLORADORA (Incurved). Wine-crimson. Flowers produced with remarkable profusion upon good stems. Moderately incurved. 25 cents each.

FORBES-ROBERTSON (Straight). Beautiful reddish-orange. A very satisfactory variety, flowers having long, straight, star-shaped petals. There is a profusion of smaller narrow, thread-like petals or secondary florets which intermingle with the main florets, making it one of the most novel varieties. 25 cents each.

FRENCH MARATHON (Hybrid). Fa beautiful deep, rich purple. Large flower, and one of the best of its color. 50 cents each.

GENERAL BULLER (Straight). A rich, velvety crimson-maroon, tipped white. Occasionally a solid crimson flower on same stalk. One of the most attractive Fancy Cactus varieties. 20 cents each.

GLORY OF WILTS (Incurved). This is a magnifcent Incurved Cactus Dahlia, the flowers being large, charmingly beautiful and perfect for exhibition purposes. Color, a rich, deep, goldenyellow-a most beautiful color. 75 cents each.

GOLDEN GEM (Straight). One of the finest golden yellow Cactus Dahlias we have had the pleasure of offering. It is first-class in every way and attracted much attention this past season. 50 cents each.

GOLDEN WAVE (Incurved). A magnificent Cactus Dahlia; flowers are large. A rich deep, pure yellow - a most beautiful color. 35 cents each.

GOLIATH (Hybrid). Yellow, tinged with salmon; broad petals; distinct. 20 cents each.

HELENE (Straight). The color is an exceedingly beautiful lavender-pink, gradually changing to white at the center; free-flowering. 35 cents each.
HENRI CAYEUX (Straight). A variety of immense size and perfect form. Color, an old gold shading to golden yellow; plants very vigorous 25 cents each.

H. G. ALFORD (Straight). A beautiful pale yellow, edged and shaded amber and pink. 25 cents each.

ICEBERG (Straight). Ivory white, with pale yel- low cast at center. Petals long, quilled and narrow. Extra fine form. 25 cents each.

INDOMITABLE (Incurved). Rich mauve-lilac; tips of petals pale lilac; very large. 50 cents each.

JEANNETTE (Straight). Unquestionably the very finest buttercup yellow Cactus Dahlia to date. Flowers of large size and produced upon good stems well above the foliage. A model of perfection in shape. 25 cents each.

J. H. JACKSON (Straight). The finest black Cactus Dahlia in existence. An exceptionally satisfactory all-round Dahlia; one of the most prominent for garden decoration; superb as a cut-flower variety and equally good as an exhibition flower. Color, a perfectly gorgeous, deep velvety, blackishmaroon. Gigantic in size. Every Dahlia lover should grow this variety. 25 cents each.

J. WEIR FIFE (Straight). Dark maroon, occasionally shading to bright purple. A beautifully formed, free-blossoming Dahlia. 25 cents each.

KATHLEEN BRYANT (Incurved). A very deep, rich, velvety crimson. One of the finest of its color. Moderately incurved. 25 cents each.

KING EDWARD VII (Straight). Brilliant cherryred. A beautifully shaped flower, possessing very long, straight, star-shaped petals. 20 cents each.

KREIMHILDE (Hybrid). The queen o the Cactus Dahlias. Color, flesh (delicate pink), shading to white in the center; very late flowering. 20 cents each.

LADY COLIN CAMPBELL (Incurved). Golden vellow at base of florets, tipped with deep orange. 25 cents each.

LADY FAIR (Incurved). (See illustration on page 19). "Lady Fair" is a new variety of unique formation, the florets being very long, narrow and daintily fringed at the ends, which makes it entirely different from any other variety in existence. In addition to the ordinary florets, there are a great profusion of long, narrow, thread-like flaments or secondary florets, which no other variety possesses. The color is an exquisite shade of primrose, daintily orerlaid soft pink. A very late flowering variety, but one of the finest novelties in the Dahlia world. 25 cents.

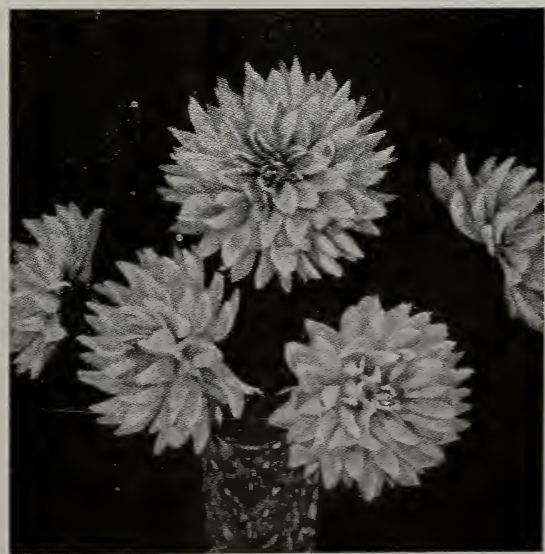

Ruth Forbes-Hybrid Cactus Dahlia (See page 15.) 
LIBELLE (Straight). Clear, deep rose-purple. 25 cents each.

LUCIFER. Deep orange-red or bronze color. A large flower. 50 cts. each.

LAURANIA (Incurved). Orange, terra cotta and cinnamon; large, bold flowers of good incurved form. Plants quite robust; very free blooming, producing immense flowers. 35 cents each.

MADEMOISELLE GALY MIQUEL. (Hybrid). A superb new French variety of special merit. The color is a beautiful clear white, daintily marbled a pleasing rose-violet, giving it the appearance of a delicate pink-and-white. 75 cents each.

MARTHA (Straight). An exquisite old rose shaded with primrose yellow at the center. Flowers are of exceptionally good size, perfect form, and borne on long, wiry stems. 50 cents each.

MARGUERITE BOUCHON (Straight). One of the finest pink exhibition Dahlias to date. The coloris a brilliant rose-pink with delicate white center. The flowers are large and borne on stiff stems, well above the foliag $\rightarrow 75$ cents each,

MARJORIE CASTLETON (Straight). The outer florets are of a pleasing shade of rose-pink, while the tips and central florets are cream white. 25 cents each.

MASTER CARL (Hybrid). One of the most satisfactory Dahlias grown. Color, an exquisite shade of bright amber. Very large. 50 cents each

METEOR (Incurved). A Fancy Cactus Dahlia, with white ground, splashed, striped and spotted with violet-purple. Very attractive. Moderately incurved. 35 cents each.

MISS DOROTHY OLIVER I (Straight). Primrose at base, tipped pure white. Very narrow. florets. Delicate and attractive. 20 cents each.

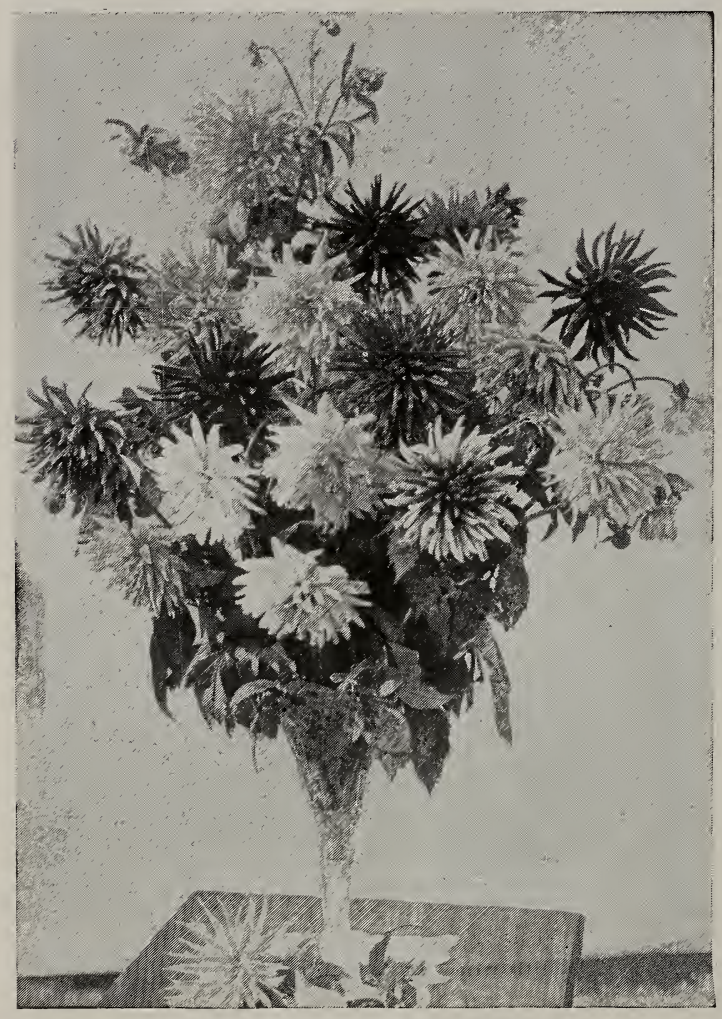

COLLEGTION OF 18 CACTUS DAHLIAS FOR $\$ 3.00$, PREPAID.

No.

1 Eureka

2 Mme. Henri Cayeux

3 Clara G. Stred wick

4 Henri Cayeux

5 Alight

6 W. B. Childs

7 Bornemann's Liebling

8 Floradora

9 J. H. Jackson

No.

10 Columbia

11 Bedinia

12 Thomas Challis

13 Libelle

14 Mrs. George Castleton

15 General Buller

16 Helene

17 Stern

18 Wm. Marshall

I highly recommend this collection.
MME. HENRI CAYEUX (Straight). (See illustration). A reliable exhibition variety. The flowers are of the largest size with long, narrow florets, forming a bloom of magnificent form. The color is a beautiful rich pink daintily tipped white. I highly recommend this grand variety as one of the best in existence. 35 cents each.

MR. KEITH (Straight). Velvety crimson. 35 cents each.

MRS. CLINTON (Incurved). Deep orange yellow at the base, shading off to pale salmon-red at the ends of the petals. Large and free flowering. 50 cents each.

MRS. DE LUCA (Straight). Golden yellow, tipped with orange. A most effective blending of colors, seen only in the very rare types. 25 cents each.

MRS. F. G.RINSTEAD (Incurved). A deep, rich crimson with just a suspicion of purplish shading. Petals in; curved; flowers of large exhibition size. 25 cents each.

MRS. GEORGE CASTLETON (Straight). This is one of the finest dark shades ever introduced. The color is a velvety blackish maroon, shaded purple. Pctals remarkably narrow and tightly quilled. 35 cents each.

MRS. HENRY WIRTH (Straight), One of the first Cactus Dahlias to bloom and exceptionally free-flowering. The perfect flowers are a bright fiery scarlet. 35 cents each.

MRS. HOBART (Straight). Pale orange and delicate shades of yellow. Large 20 cents each.

MRS. H. L. BROUSON (Straight). A clear, delicate salmon or pale orangeyellow, with long petals. Fine. 20 cents each.

MRS. WM. MARSHALL. Soft pink, base of florets deeper in tint, large creamy white center; a great acquisition. 35 cents.

MRS. W. H. RABY (Straight). The flowers are of extra fine form. The color is cream-white. 25 cents each.

MRS. WINCHESTER (Straight). A charming, deep coral-pink shade. 35 cents each. 
NISI PRIUS (Incurved). A very novel combination of orange-red and fawn to plum, with a blending of golden yellow at center. Moderately incurved. Flower of large size. 25 cents each.

OSPRAY (Straight). An attractive Fancy Cactus variety, the color being golden yellow, splashed and striped scarlet. 20 cents each.

PERLE DE LYON ( $\mathrm{Hy}-$ brid). A pure white exhibition variety of great value. Petals fringed or nicked, giving unique appearance. 35 cents each.

PINK PEARL (Hybrid) Clear bright pink. 25 cents each.

PRINCE OF ORANGE (Straight). One of the most attractive varieties. A rich shade of old gold at the outer petals with a bright yellow center; very showy. 20 cents each.

P. W. TULLOCK (Incurved). Deep reddish salmon. Free flowering. Slightly incurved. 20 cents each.

RADIANCE (Straight). Beautiful orange-scarlet. 35 cents each.

RENE CAYEUX (Straight). An exceptionally free-flowering variety. Flowers are of good size and are a beautiful ruby-crimson; are borne on long stems. Excellent for exhibition. 25 cents each.

RELIABLE. (Straight). This variety is most appropriately named, it being one of the most reliable we grow. A novel, but very pleasing combination of yellow, brick-red and salmon. Exceptionally free-flowering. 25 cents.

REV. DR. BAKER (Straight). One of the most satisfactory Dahlias we have ever grown, always being covered with large and perfect flowers. The coloring is very odd, being a novel shade of plum. Excellent for exhibition or garden purposes. 50 cents each.

ROSA STARR (Straight). A very beautiful lilacpink. One of the finest novelties. In addition to the long quilled petals common to all Cactus Dahlias, this variety has very fine needle-like inner petals which are a great addition to this variety, and make it entirely distinct from the other Cactus varieties. 50 cents each.

ROSALIND (Straight). A sterling New Garden Cactus of perfect form. Color, a delicate shade of rose-pink, daintily suffusing to cream in the center, faintly tipped white. One of the most reliable. 50 cents each.

RUBY GRINSTEAD (Incurved). The center is a soft tone of yellow which is gradually suffused until it becomes a rich shade of rose-fawn, the outer incurving petals being a very light salmonpink, making it very attractive. 25 cents each.

RUTH FORBES (Hybrid). (See illustration on page 13). The massive, clear pink flowers, composed of heavy petals, are often accompanied by stems measuring 2 feet in length; excel any other variety for large vase purposes. 25 cents each.

SALMON QUEEN (Straight). A large, beautifully formed bloom with yellow center and salmon tips. 50 cents each.

SANDY (Straight). Golden orange, suffused with fawn. A flower of great substance and durability. 50 cents each.

STAR (Straight). Yellow and orange. A fine variety for all purposes; cutting, exhibition and garden. 50 cents each.

SIRIUS (Straight). Bright golden yellow, heavily striped with scarlet. Large, very attractive flowers. 20 cents each.

SNOWDON (Incurved). Purest white. 50 cents each.

STELLA (Hybrid). Rich, vivid scarlet; deep, bold flower. 25 cents each.

STERN (Straight). Bright primrose-yellow. The flowers are large; petals long and pointed. One of the most satisfactory varieties. 20 cents each.

STORMER (Incurved). A scarlet of the finest form. One of the most reliable varieties to date. 35 cents each.

T. G. BAKER (Incurved). Clear yellow, 25 cents each.

THOMAS CHALLIS (Incurved). A very rich tone of salmon-red or rosy-salmon. The florets are beautifully incurved and arranged with the utmost regularity. This variety can be recommended as one of the best for cut-flower purposes. 35 cents each.

THURININGIA (Straight). Light flame color. 50 cents each.

TUSTU (Straight). One of the most beautiful to date. The color is perfectly gorgeous-a beautiful velvety maroon. The petals are very long. tightly quilled and arranged in exact regularity. completing an acquisition which we can highly recommend. 50 cents each. 


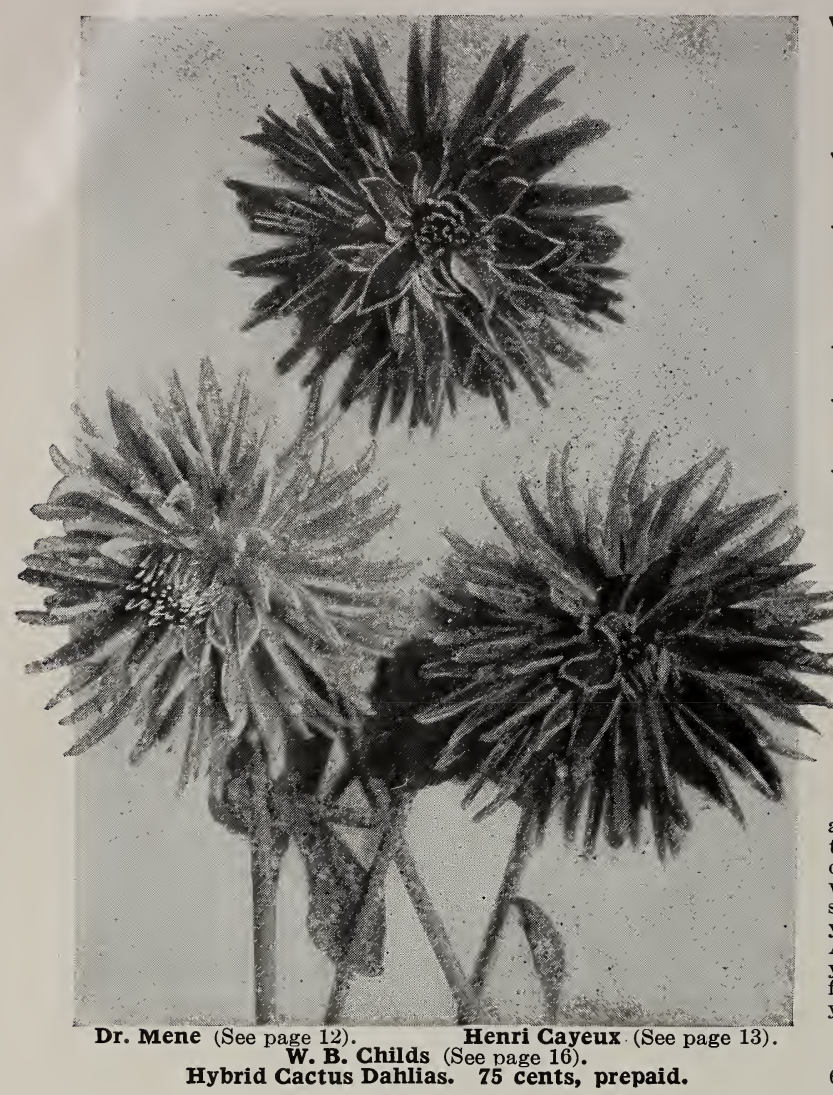

VARIABILIS (Hybrid.) A novelty of most graceful character. Beautiful deep orange artistically tipped pure white. The petals are fringed or nicked and very gracefully incurved. 35 cents each.

VOLKER (Straight). A soft clear yellow of medium size. 20 cents each.

W B. CHILDS (Hybrid). (See illustration.) A very reliable variety. Color a beautiful dark maroon. Flowers extra large. 35 cents each.

WHITE SWAN (Straight). A beautiful pure white. 25 cents each.

WM. JOWETT (Hybrid). Brilliant scarlet; a large, well-formed flower. 50 cents each.

WM. MARSHALL (Straight). Very large. A beautiful rich orange with golden yellow center. The habit of the plant is very good, being tall, robust, and producing its immense flowers well above the foliage. 25 cents each.

Great Falls, Mont. Nov. 18th, 1919.

J. K. Alexander.

Dear Sir: Last Spring I sent you a small order for Dahlias. When they came I didn't like their looks, or didn't think they would grow, and so wrote you. I received a card from you saying I could return the roots. When your card came I had planted them. All summer $I$ have intended to write you that every one grew and made fine plants. This, I thought, was due you, as I had found fault. Respectfully,

Mrs. Mary L. Burlingame.

601 Third Ave. N., Great Falls, Mont.

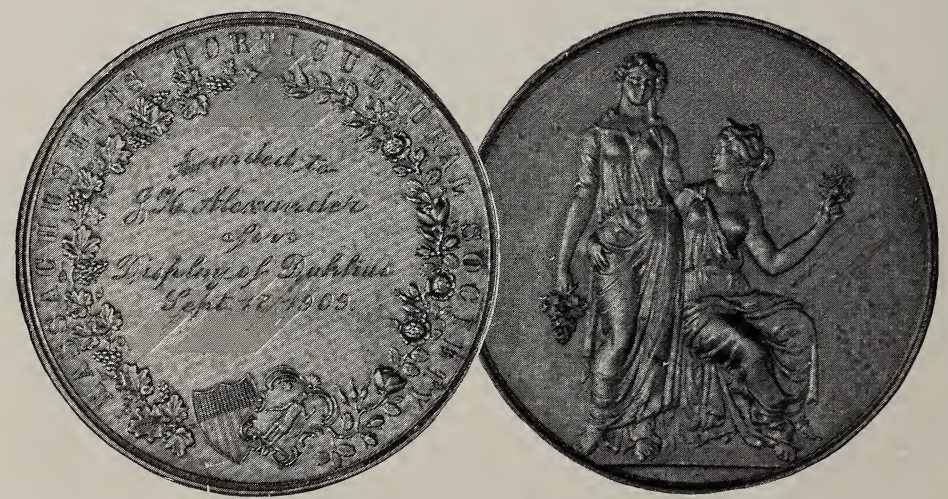

THIS MEDAL WAS AWARDED ME FOR THE BEST DISPLAY OF CACTUS AND DECORATIVE DAHLIAS EXHIBITED AT HORTICULTURAL HALL, BOSTON, SEPTEMBER, 1909 


\section{The Peony-Flowered Dahlias}

In presenting my list of new and selected varieties of Peony-flowered Dahlias, I wish to devote a few line to the history of this comparatively new type of Dahlia; a section which I think will interest all flower lovers.

Prompted by the great popularity of the Cactus Dahlia, then so different from the stiff, ball-shaped Dahlias but only beautiful for exhibition, lacking the grace and freedom to flower of the Single Dahlia, European hybridizers saw the possibility of making a type suitable for garden and cut-flower purposes.

By crossing the Cactus and other Hybrid Dahlias with the Single, and vice versa, they developed quite a new type - the Peony-flowered Dahlia-now popular all over the world. These long stemmed, semi-double Dahlias were grown in Holland, and sold as Half-double Giant Dahlias. Mr. H. Hornsveld, an Orchid specialist of Baarn, Holland, immediately saw their possibilities and collected the largest and most promising specimens. The great development and present value of the Peony-flowered type is due to him. After seven years of cross-hybridizing and developing (July, 1904), he was able to show the results at the meeting of the Dutch Horticultural Society at Rosendaal, where he exhibited four varieties, Queen Wilhelmina, Duke Henry, Baron G. de Grancy and Glory of Baarn. Here he received a first-class Certificate of Merit, and the admiration and encouragement of growers and Dahlia lovers. A still greater success was accorded him that same season at the International Exhibition at Dusseldorf, Germany, where he gained the highest awards. The horticultural world gathered at the Show was charmed by the elegant and artistic form, the strong stems, and the delicate colors of the flowers. Mr. Kerr of Liverpool exclaimed, "Hornsveld's Dahlias are the pride of the Show. After Dusseldorf came Paris. A gold medal and special compliments of the jury were the laurels Mr. Hornsvela gathered there. Amsterdam, London, Brussels and other places followed, where he had the same good fortune.

With this encouragement he continued experimenting and introducing new things, and as his stock increased sufficiently, he distributed them throughout Holland. Because of their great value for cut flower purposes and garden decoration, their popularity increased rapidly, and they were exported to other countries.

English and American Dahlia Specialists, seeing their value, immediately commenced experimenting, and to-day every up-to-date Dahlia specialist offers a collection, not only containing the best and latest Holland productions, but also English and American creations.

\section{New Peony-Flowered Dahlias for 1920}

\section{I will ship this collection of $31 \mathrm{New}$ Peony-flowered Dahlias prepaid for $\$ 50.00$.}

ALTA POWELL. Alexander's New Peony-flowered Seedling. A very bright lemon yellow, overlaid, blending to and edged carmine red. The plants are very tall and sturdy, producing their flowers on long stiff stems, well above the foliage. This new seedling is one of the most free-flowering varieties I have seen, making it a very desirable garden variety. Named for Miss Alta Powell of New Haven, Conn. \$2.00 each.

BESSIE SEABURY. Alexander's New Peony-flowered Seedling. White very daintily overlaid a delicate mallow pink. An exceptionally free-flowering variety, of good habit, that produces its blossoms on good long stems. Named for and by permission of Mrs. William T. Seabury, North Weymouth, Mass., a great admirer of beautiful flowers. \$2.00 each.

BERTHA PAULDING. (Alexander). A very striking variety for the garden, growing five feet and over in height. The plant is strong and sturdy, producing a large number of blooms on long stems. The flowers are of an exquisite, deep, rose-pink, of good depth and with an open center. Altogether one of the best pinks of its type. Price, $\$ 3.00$ each.

CALIFORNIA. Introduced from Holland as a Peony-flowered Dahlia, but with us, it has characteristics of both the Decorative and Peony-flowered types. The early flowers are full to the center, with broad petals that are somewhat pointed and long, like the true-Decorative. As the season advances, the flowers show that beautiful golden yellow center, so characteristic of the Peony-flowered type. In color, it is a beautiful clear rich deep yellow, which makes it without exception one of the very finest yellow Dahlias to date. The blossoms are large, and produced upon good long stiff stems. Yery free-flowering. $\$ 1.00$ each.

CARDINAL. New Holland Peony-flowered Dahlia. A very large flower that early in the season comes nearly full to the centre, and of a gorgeous maroon-purple. The stems are unusually good, being long and very strong, producing the flowers well above the foliage. The best of this color to my knowledge. $\$ 1.00$ each.
CREATrON. Holland Peony-flowered Dahlia. This new variety has a very pleasing and unique shade, one not common in Dahlias; a beautiful rosered, that wins instant favor. Flowers of medium size and produced freely upon long stems. Good cut-flower short. $\$ 1.00$ each.

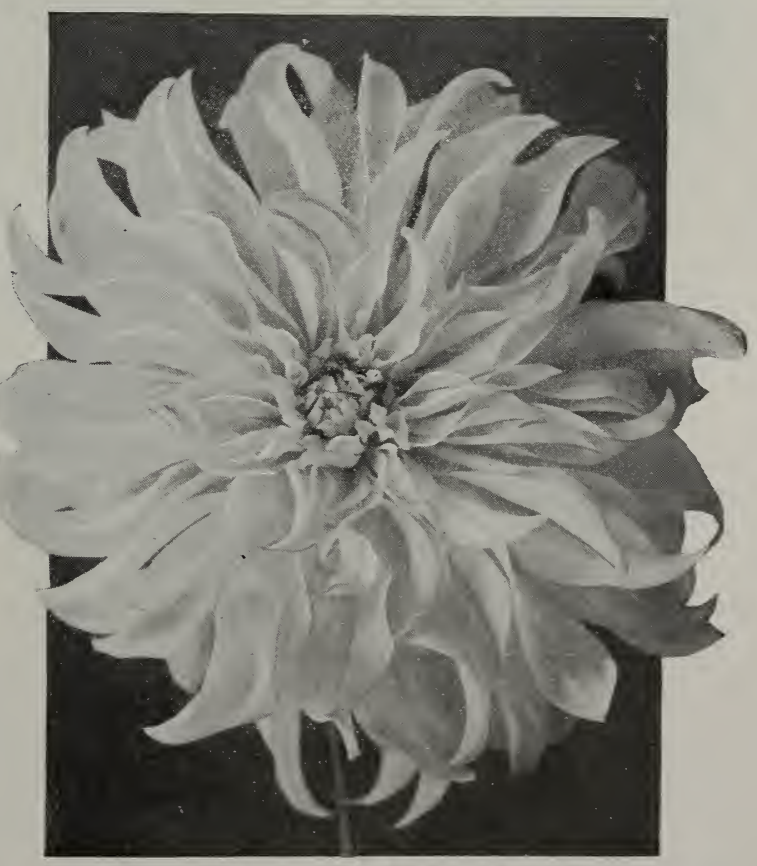

MADONNA. 25c each; $\$ 2.50$ per dozen. (See page 21.) 


\section{PEONY FLOWERED DAHLIAS-Continued.}

ELLEN E. KELLY. New Peony-flowered Dahlia. A long-stemmed free-flowering golden-yellow variety that attracted considerable attention in my gardens this past season, being admired by many, and named for one of my customers, in recognition of her great love of beautiful flowers. This variety is highly recommended, and has all the good qualities of the Dahlia. \$2.00 each.

\section{GERTRUDE BURBANK. Alexander's New} Peony-flowered Seedling. Named expressly for Mrs: Gertrude Burbank of Waco, Texas, who admired this new creation when she visited my gardens this past fall, and I take pleasure in naming it for her. The flowers are very large, and of a brilliant scarlet-red. Petals are perfectly original, being long and Cactus-like. This creation is a seedling from the popular variety "Geisha." The plants are very tall, producing their flowers upon long stems. \$1.00 each.

GRACE KIRSCHNER. Alexander's New Peonyflowered Seedling. White daintily overlaid cameopink. Its blossoms are very large, and exceptionally fine. One of the most delicate of this collection. Named expressly for and with permission of Mrs. Kirschner of Hamden, Connecticut, in appreciation of her admiration for Dahlias. $\$ 3.00$ each.

JEANIE PRESTON. Alexander's New Peonyflowered Seedling. Named expressly for and with special permission of one of our customers, in recognition of her fondness of beautiful flowers.

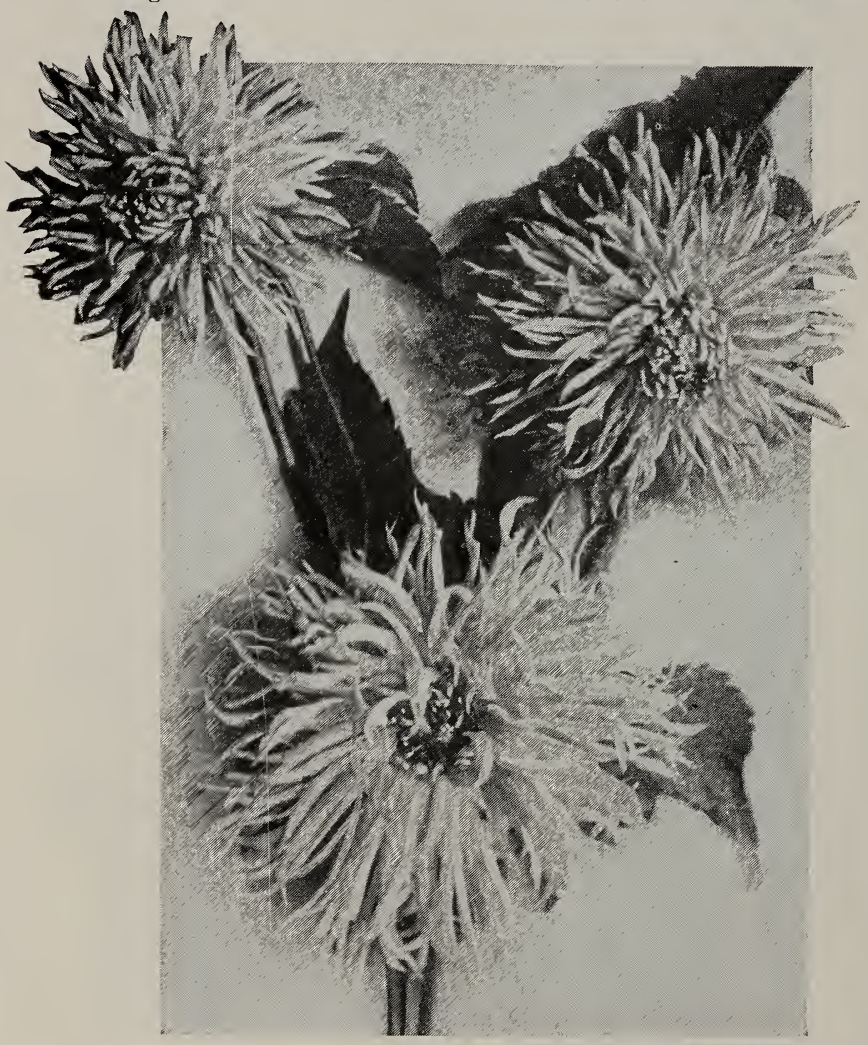

Lady Fair.
In color, a pale lemon-yellow shading to Martinus yellow, overlaid a delicate Japan rose. Reverse of petals a deep Japan rose. This is my largest and finest rich yellow Peony-flowered seedling, and I can highly recommend it. Flowers of gigantic size, and produced on good long stems, well above the foliage. $\$ 5.00$ each.

JONTEEL. Alexander's New Peony-flowered Seedling. Beautiful pale corinthian pink blending to golden yellow at the center. Good long stems. $\$ 1.00$ each.

KATHINKA ANDERSEN. Alexander's New Peony-flowered Seedling. Named for one of my customers, Kathinka Andersen of Castle Dale, Utah. A beautiful lemon-yellow, exquisitely overlaid pale amaranth pink. \$2.00 each.

LATONA. New Holland Peony-flowered Dahlia. An unusual blending of orange, buff and yellow. Flowers are nearly full to the center, and produced freely, upon good stems. \$1.00 each.

LOUIS GRATON. Named expressly for and with permission of Mr. Louis Graton, the Strawberry Specialist of Whitman, Mass. A very delicate pale salmon, blending to golden-yellow at the center. $\$ 2.00$ each.

MARY E. MCKEEVER. Alexander's New Peonyflowered Seedling. A long stemmed, free-flowering variety, named for Mrs. William J. McKeever of Boston, Mass., in recognition of her great love for flowers. A very delicate light rosol ne-purple daintily overlaid rose-purple with yellow ring at center. \$2.00 each.

MRS. A. E. BEALS. Alexander' New Peony-flowered Seedling. Named expressly for and with permission of Mrs. A. E. Beals of North Weymouth, Mass., as an attribute to her fondness for beautiful flowers. Cream color, very heavily overlaid a rosy purple, the general appearance being a deep rose-pink. Blossoms of large size, produced upon long stems, well above the foliage. $\$ 3.00$ each.

MISS BARBARA HAMMOND. Alexander's New Peony-flowered Seedling. An exquisite shade of silvery rosolane-pink, blending to clear pale lemonyellow at the center. One of the most beautiful. A very tal growing plant, producing its blossoms upon long stems. $\$ 3.00$ each

MISS DORIS BIRD. New Peonyflowered Seedling. One of the best of my new seedlings, of a clear rose-red shade. Flowers of large size. \$2.00 each.

MISS LYMENA T. BAXTER. Alexander's New Peony-flowered Seedling. Namely expressly for and with permission of Miss Lymena T. Baxter of Barnstable, Mass, in recognition of her great love for flowers. This new creation received an Honorable Mention at the September Dahlia Exhibition of the Massachusetts Horticultural Society; the highest award given to a seedling exhibited for the first time. The habit of the plant is all that could be desired; the plants growing into perfect specimens, and producing a great abundance of flowers upon long stems, well above the foliage. The coloring is a very beautiful clear pale lemon-yellow. An ideal Dahlia in every respect, and one that has my highest recommendation. $\$ 5.00$ each. 
MINA SEABURY. Alexander's New Peonyflowered Seedling. Named expressly for Mrs. Philip Seabury of Boston, Mass., who elected this variety from my collection of seedlings, as one of the most beautiful; surely an attribute to Mrs. Seabury's good judgment of beautiful flowers. A very large flower, with long curling petals, that is destined to become a great favorite. In color, a sulphur-yellow, very daintily overlaid mallow pink. $\$ 3.00$ each.

MRS. J. H. BENTON. (Alexander.) A large, full, deep flower with long, strong stems. The color is white, suffused a delicate yellow; the reverse of the petals are streaked carmine, which delicately tints the whole flower. Planes are very tall and vigorous. Really a beautiful variety. Price, $\$ 3.00$ each.

MRS. WALTER C. BAYLIES. Alexander's New Peony-flowered Seedling. Named expressly for Mrs. Walter C. Baylies of Taunton, Mass., and selected by Mrs. Baylies from a large number of our seedlings; surely a favorite, as everyone who saw it spoke admiringly. Its flowers are exceptionally large, and each petal curves gracefully. In color, a pale lemon yellow; blending to sulphur yellow at the tips. I can highly recommend this new creation, as it was one of the very best, and produced its gigantic blossoms in great abundance. $\$ 5.00$ each.

MRS. NEWELL D. ATWOOD. Alexander's New Peony-flowered Seedling. A very tall, longstemmed, free-flowering variety. Its color is very rich and brilliant; a gorgeous deep crimson-red. Its plants were very strong, sturdy growers, and it promises to become one of the most popular. Named in honor of Mrs. Newell D. Atwood of Ossamequin Pines and Boston, Mass., a great admirer of beautiful flowers. $\$ 3.00$ each.

OSSAMEQUIN. Alexander's New Peonyflowered Seedling. Pale lemon yellow, heavily striped and splashed carmine-red. Free-flowering, and with good stems. $\$ 2.00$ each.

POMPEIAN BEAUTY. Alexander's New Peony-flowered Seedling. Pale salmon daintily overlaid old rose. Exceptionally free-flowering. Two or three rows of petals. $\$ 1.00$ each.

ROSE GEM. A new variety imported this last season from Holland, and one that proves to be one of the finest of its color to date. The habit of the plant is perfect, it being a good strong growing variety producing its blooms upon strong stiff stem well above the foliage.

- The coloring is very beautiful and something entirely new; a pleasing shade of salmon-pink with a silvery sheen. We think Rose Gem properly named as it is surely a gem among Dahlias. $\$ 1.00$ each.

SALVATOR. New Hclland Peony-flowered Dahlia. Deep rose-pink blossoms, plants of medium height, and edges of petals are of a curling nature, giving the flower an entirely original appearance. $\$ 1.00$ each.

SARA W. ASHENDEN. Alexander's New Peony-flowered Seedling. A most beautiful shade of rhodamine purple. Flowers borne upon long strong stems, well above the foliage, and for vases and house decoration are especially good, lasting long after cut. This new seedling was greatlyadmired by Mrs. Ashenden when first exhibited and was named in her honor. $\$ 3.00$ each.

THE RHODES. Alexander's New Peony-flowered Seedling. 1 tive shade of pale rosolane pink with a dainty blending of yellow at the center. This new creation was, exhibited for the first time last September in the collection of twelve best Peony-flowered Dahlias at the Dahlia exhibition of the Massachusetts Horticultural Society, the collection winning first premium, against strong competition. The flowers are very large and of a very delicate blending of colors. Very good for exhibition purposes. $\$ 3.00$ each.

WAMPATUCK. Alexander's New Peony-flowered Seedling. Similar in color combinations to "Twentieth Century" but larger and of deeper color. An exquisite cream shade, very heavily overlaid rose-purple. $\$ 2.00$ each.

\section{WAMPUM. Alexander's New Peony-flowered} Seedling. Pale barium-yellow, hearily striped and splashed crimson-scarlet. Long stems and very free-flowering. $\$ 1.00$ each.

$$
\begin{aligned}
& 9747 \text { Commercial Arenue, } \\
& \text { Chicago, Ill., } \\
& \text { June 4, } 1919 .
\end{aligned}
$$

Mr. J. K. Alexander,

Dear Sir,-

Thank you very much for the prompt filling of $m y$ order. I was delighted with everything and especially with the extra fine species of Gladioli and Dahlias. I thank you very much for all. The Phlox, Iris and Tiger Lillies have taken root, and are sturdy and green, and I hope my Dahlias and Gladioli will give me much pleasure.

I thank you again,

$$
\text { Mrs. F. W. Reith. }
$$

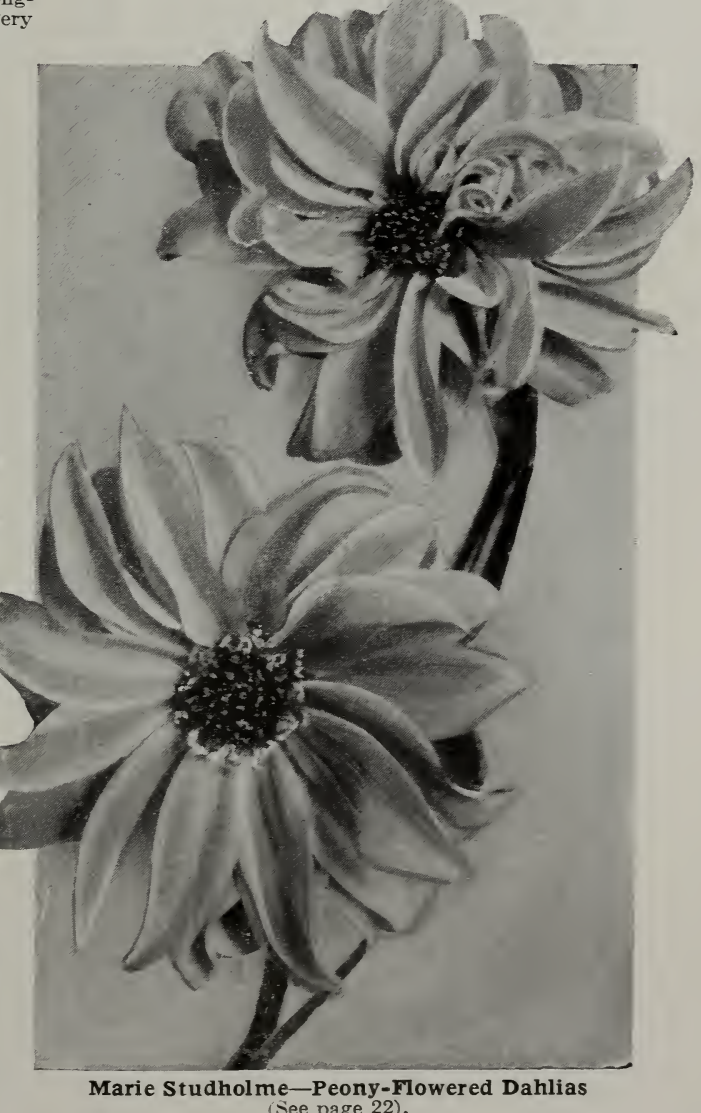

Marie Studholme-Peony-Flowered Dahlias (See page 22). 


\section{Peony-Flowered Dahlias \\ Up-to-date Varieties for 1920}

I will ship this collection of $14 \mathrm{Up-to-date} \mathrm{Peony-flowered} \mathrm{Dahlias} \mathrm{for} \$ 10.00$, prepaid.

ANNY DOPPENBERG. A new Holland introduction with an Award of Merit to its credit. The color is sulphur-yellow, and the habit of the plant is all that could be desired. \$1.00 each.

ATLANTA. (Alexander.) Remarkable Peonyflowered Seedling. An ideal flower of remarkable qualities; flowers beautifully formed and of excellent type. Unquestionably the most valuable white Peony-flowered variety. $\$ 1.00$ each.

CARL PURDY. New Peony-flowered Seedling (to the credit of Mr. Vanderbilt of San Rafael, Cal.) A wonderful introduction in every respect. The flowers are very large, held erect on long, strong stems. Color, a bright, fiery scarlet. The plants are of excellent habit and of a particularly strong constitution. $\$ 2.00$ each.

COPPER. This is one of the best late California introductions, a marvel of beauty. An immense flower with very unique coloring: copper, shaded and tinted with bronze and apricot, with a suggestion of salmon-pink. The petals are broad, fluffy and twisted, giving a full, deep effect. Price, $\$ 1.00$ each.

DUCHESS OF BRUNSWICK. New Holland Peonyflowered Dahlia. A beautiful shade of red in the center, the outside of the florets being apricot. Awarded First-class Certificate at Amsterdam and Haarlem. First-class Certificate by National Dahlia Society, and Award of Merit by Royal Horticultural Society, London. $\$ \mathbf{\$ 1 . 0 0}$ each.

JOHN WANAMAKER. A fine free bloomer with strong stems of good length. Color, a pleasing shade of violet-mauve. This variety should be in every garden. 50 cents each.
MARY LINDER. “Alexander's Peony-flowered Introduction. "Mary Linder" is a seedling from the popular Hybrid Cactus Dahlia "Master Carl," possessing the charming golden orange color of that variety, but being true Peony in type. The flowers are not large, but good medium size, and are produced with freedom on good stems. This variety was originated by one of my customers, Mr. John Linder of Canton, Mass., and through his courtesy I have the pleasure of introducing it. 75 cents each.

MME. VAN BYSTEIN. A very distinct and new shade, lilac-blue throughout. Plants tall and sturdy, holding blooms well above the foliage. Large and fine. \$1.00 each.

MRS. BOWEN TUFTS. Alexander's Gigantic Peony-flowered Seedling. Named expressly for and by permission of Mrs. Bowen Tufts of Boston and Allerton, Mass., in recognition of her admiration for the beautiful. This creation is the finest of my new Peony-flowered Dahlias, having gigantic, deep rosy purple blossoms, which are produced well above the foliage upon long, graceful stems. The habit of the plant is excellent flower stems being long and the bushes tall and exceptionally sturdy. $\$ 1.00$ each.

MRS. G. DRUMMOND. This is a great acquisition. The color is a beautiful apricot, suffused with salmon-a distinct and lovely shade. A perfect cut flower and a free bloomer. 25 cents each.

MRS. GEORGE GORDON. A delicate creamy white flower of large size. The plant has a good upright habit of growth and is a free bloomer. One of the best whites to date. 50 cents each.

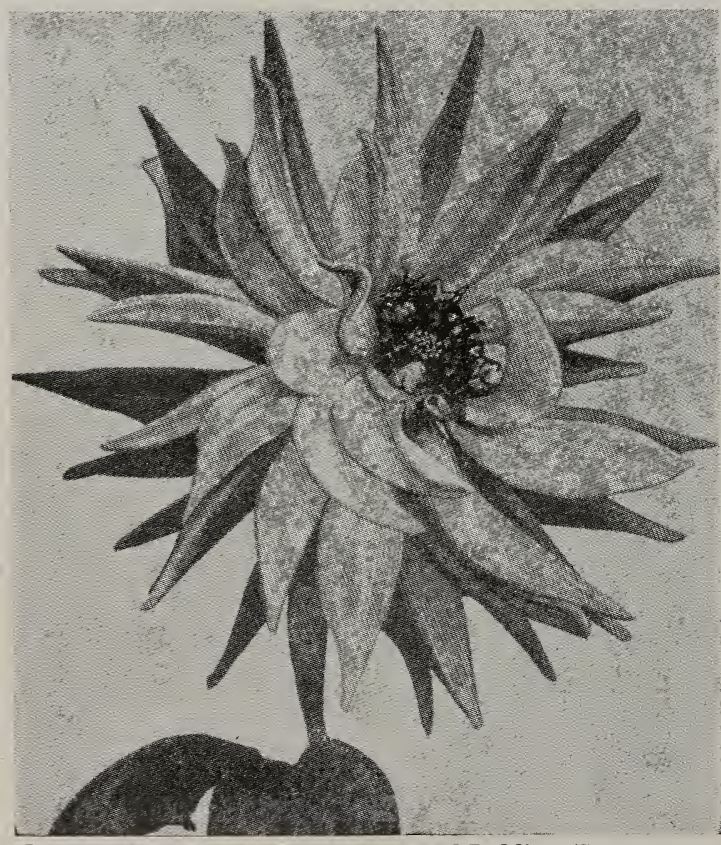

John Green-English Peony-Flowered Dahlia. (See page 21.)
MRS. GRACE BOLLES. Alexander's Beautiful Peony-flowered Seedling. A variety that is very appropriately named one of the most graceful to date. The plants are of perfect form -a pleasing upright style of growth and produce flowers in great abundance. The flowers are of large size. The coloring is most exquisite, sweetest rose-salmon, with a blending of golden yellow at center. This variety bears my highest recommendation. $\$ 1.00$ each.

PRINCE CAMILLE. One of the finest Peony-flowered Dahlias we have seen. Color, velvety crimson, shaded rose. 50 cents each.

MRS. M. W. CROWELL. A remarkably sturdy variety of perfect habit. Color, a beautiful orange-yellow. 5 cents each.

\section{Codwise Avenue, New Brunswick, N.J.}

Mr. J. K. Alexander, June 5, 1919

East Bridgewater, Mass.

Dear Sir,-

Received the replace bulb O.K. and was surprised a few days later to receive another bulb, "Reine Cayeux," and wish to thank you very much for both; also for the premium bulb sent with the regular order. All are growing fine, and will certainly send you another order in the Spring if we do not move.

Yours truly John A. Flagg. 


\section{General List of Select Standard Peony-Flowered Dahlias}

A collection of the choicest Standard Peony-flowered Dahlias in existence; the finest collection ever offered $\mathrm{n}$ this country; introductions from all over the world, together with some of the choicest seedlings I ever introduced. I will send this Phenomenal Collection of 34 Fashionable Peony-flowered Dahlias prepaid for for $\$ 10.00$.

BARON G. de GRANCY. (See Madonna.)

BERTHA VON SUTTNER. Giant Holland Peonyflowered Dahlia. A very beautiful shade of salmon-pink, delicately overlaid yellow. It is very similar to "H. Hornsveld," having elegant twisted petals. 50 cents each.

CAECILIA. Gigantic Holland Peony-flowered Dahlia. A magnificent flower of great individuality; one that will give perfect satisfaction. A wonderfully large creamy white flower. 50 cents each.

CAESAR. Holland Peony-flowered Dahlia. Large flowers of a rich shade of canary-yellow. Tery strong grower. First-class Certificate. 35 cents each.

DR. K. W. VAN GORKUM. Holland Peony-flowered Dahlia. White, heavily shaded rose. 35 cents each.

DR. PEARY. Gigantic Holland Peony-flowered Dahlia. Without exception the very finest dark Peony-flowered Dahlia in existence. A rich, velvety wine-crimson or dark mahogany. Flowers of gigantic size and identical in form and shape to the "Geisha." A variety which I highly recommend. 50 cents each.

ELECTRA. The coloring of this variety is exceedingly wonderful, a bluish mauve shade, with an exquisite golden yellow center, which combines to give this variety a prominent place in the Peonyflowered type. Free-flowering. First-class Certificate. 50 cents each.

ELINOR A. INNES. Alexander's Peony-flowered Seedling. Named expressly for and by permission of Mrs. Charles H. Innes of Boston and North Scituate, Mass., in recognition of her great love of the Dahlia. Flower is a beautiful purple with an exquisite yellow center, which lends an additional charm to the entire flower. Very free-flowering. $\$ 1.00$ each.

FRAULEIN BUDDE. Beautiful Holland Peonyflowered Dahlia. A charming soft mauve-violet with an exquisite golden-yellow center, which combines to make the flowers most beautiful. Award of Merit. $\mathbf{5 0}$ cents each.

GEISHA. Wonderful Holland Peony-flowered Dahlia. The pride of the Peony-flowered Dahlias. This most sensational variety is the showiest and most attractive of this type in existence. It is a superb combination of brilliant scarlet and gold with an exquisite ring of rich clear golden yellow at center. Occasionally the first flower comes fully double, but all that follow show that beautiful golden yellow center which combines to make this flower the most charming. Its form is very original consisting of peculiarly twisted and curled petals which are very long and beautifully shaped. 50 cents each.

GERMANIA. Holland Peony-flowered Dahlia. Bright glowing crimson. 20 cents each.

GLORY OF BAARN. Fragrant Peony-flowered Dahlia. This most fascinating variety appeals to every flower-lover as a true sensation. The coloring is exquisite, being a delightful clear soft pink; a most pleasing flower whose light rosy tint forms a perfect contrast with the deep green foliage. Its gems are of wonderful size and produced with exceptional freedom on long, wiry stems. The beautiful golden yellow center completes the artistically arranged gem and lends an additional charm to this acquisition. 25 cents each.
GWENDOLYN. White overlaid rose-pink, free-flowering, produced on long stems. 50 cents each.

HAMPTON COURT. Up-to-date English Peonyflowered Dahlia. The best of the English creations; a Dahlia of immense size and marvelous qualities. The color is an exceedingly effective bright mauve-pink. 35 cents each.

H. J. LOVINK. Beautiful Holland Peony-flowered Dahlia. Flowers large and produced upon exceptionally long, wiry stems. The coloring is very delicate- - hite, daintily blending to lilac. 50 cents each.

HORTULANUS BUDDE. Gorgeous Holland Peony-flowered Dahlia. A bright deep red; of splendid habit. One of the most reliable. Award of Nierit. 35 cents each.

JOHN GREEN. English Peony-flowered Dahlia. The coloring is exceptionally attractive and intensely brilliant, the center being a clear golden-yellow which a quickly changes to fiery scarlet. A great feature of this variety is its lasting quality, the flowers remaining in full beauty for over a week, unhurt by rain or sun. The shape of the flower is perfectly original,

鹿 the petals being beautifully pointed, giving it a * star-like appearance. Awarded. First-class Certificate by the National Dahlia Society the joint committee of the Royal Horticultural Society and the National Dahlia Society at the Dahlia Trials at Duffryn, Cardiff. 50 cents each.

KING EDWARD. First-class Holland Peonyflowered Dahlia. A large purple flower of good substance. 35 cents each.

LA RIANTE. Up-to-date Fragrant Peony-flowered Novelty. This superb Peony-flowered Dahlia possesses a most charming individuality in beauty and grace which is almost indescribable and incomparable. The color, a charming lavender-pink with an exquisite golden yellow center, combines to make the flowers most beautiful. The flowers are true Peony type, but in form perfectly original; its long, graceful petals being beautifully curved and twisted, giving the whole a phenomenal, or almost unique appearance. The fragrance of this variety is remarkably prominent and encourages us to imagine a long list of Fragrant Dahlias in the near future. An ideal variety that bears our highest recommendation. 25 cents each .

LADY K. DRUMMOND. Yellow, changing to buff at the tips of the petals, shaded salmon. Free and of good habit. A really charming flower. 25 cents each.

LADY SEVILLE. A gorgeous flower of rich, orangescarlet, petals tipped buff, and slightly reflexed. A prolific bloomer, thoroughly satisfactory. 35 cents each.

LOVELINESS. Dainty Holland Peony-flowered Dahlia. This charming variety is very appropriately named. The coloring is a most exquisite pale lilac, daintily blending and shading to white. This variety will give perfect satisfaction. Award of Merit. 50 cents each.

MADONNA. Magnificent New Peony-flowered Dahlia. A perfect wonder; its remarkable qualities being beautiful shape, excellent cut-flower variety, and one of the most satisfactory in the garden. The flowers are borne in a miraculous profusion, upon long graceful stems of wiry stiffness, making it one of the most desirable. In color a very beautiful white, very slightly tinted with a most delicate shade of lavender-pink. The form is perfectly original, each petal curling and twisting in a very pleasing manner. This variety has been previously cataloged as "Baron G. de Grancy" having been imported from Holland under that name. 25 cents each. 


\section{PEONY-FLOWERED DAHLIAS-Continued.}

MARIE STUDHOLME. (See illustration on page1 9). Delicate, bright mauve-pink, shaded with a glistening ivory sheen. This beautiful combination of colors gives the appearance of a lavender-pink. The flowers are of very original form, petals being very gracefully curved and twisted. 35 cents each.

MRS. A. PLATT. Sterling English Peony-flowered Dahlia. A flower of massive proportions, but charming in general appearance. The blossoms are large and perfectly formed. The color is a magnificent bluish-pink. First-class variety; valuable for exhibition purposes. 50 cents each.

MRS. JACQUES FUTRELLE. Up-to-date Peonyflowered Seedling. Flowers of medium size, but very attractive. An exquisite lemon-yellow, heavily splashed scarlet. Very free-flowering. 25 cents each.

NEWPORT DANDY, A lilac-pink of the most delicate shade. The yellow center is open with the inner petals curling and twisting over it. A large size flower and a very profuse bloomer. \$1.00 each.

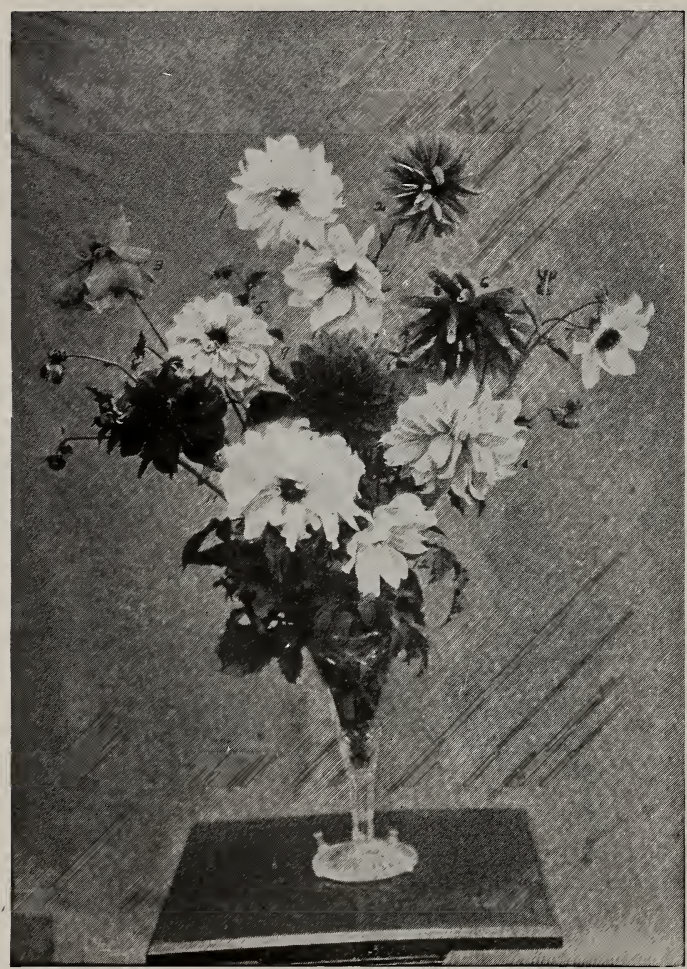

TWELVE MARVELOUS PEONY-FLOWERED DAHLIAS PREPAID FOR $\$ 3.00$.

The Flower of the Fashionable World.

No.

1 Queen Wilhelmina

2 P. W. Jansen

3 John Green

4 Glory of Baarn

5 Queen Emma

6 Phenomene
No.

7 Madonna

8 Germania

9 Mrs. M.W.Crowel

10 Marie Studholme

11 Zeppelin

12 La Rainte
PAINTED LADY. Up-to-date Holland Peonyflowered Dahlia. One of the most fascinating varieties in existence. Color, a beautiful pale rose. Award of Merit. $\mathbf{5 0}$ cents each.

P. W. JANSEN. Fragrant Peony-flowered Dahlia. A most satisfactory variety. The novel color is rosy salmon, daintily overlaid a beautiful shade of yellow; an elegant flower borne on stout, erect stems. A great addition to any collection. 25 cents each.

QUEEN EMMA. Fragrant Peony-flowered Dahlia. A delightful sort that appears almost artificial. It is a charming shade of Hollyhock pink, the inner petals banded with gold. The flowers are sensational, possessing grace, simplicity and beauty, which makes this variety exceedingly fashionable. 25 cents each.

QUEEN WILHELMINA. Giant Holland Peonyflowered Dahlia. (See illustration on page 2.) Largest and finest of the pure white sorts; excellent for decorative work and unsurpassed as a cut flower. Blossoms produced upon long, graceful stems, well above the foliage. An immense, fluffy flower of pure glistening white, showing its beautiful golden yellow center very prominently, which lends an additional charm to this most beautiful flower. 25 cents each.

SHERLOCK HOLMES, Beautiful Holland Peony-flowered Dahlia. An ideal flower, possessing remarkable qualities; flowers beautifully formed and of excellent type. A beautiful shade of mauve. 50 cents each.

SOUTH POLE. A new, large white variety, rivaling "Queen Wilhelmina." It bears the blooms freely, well above the foliage, on strong, erect stems. A welcome addition to the Peony class. $\mathbf{5 0}$ cents each.

VIRGINIA MARSHALL. Peony-fiowered Seedling. A very beautiful and delicate new variety. In shape and form the flowers are perfectly original; the petals are very long and "Geisha", like, being beautifully quilled and twisted. The blossoms are an exceptionally dainty primrose-yellow, faintly overlaid a delicate rose-lilac shade. 75 cents each.

ZEPPELIN. Holland Peony-flowered Dahlia. The incomparable delicacy and richness of this most interesting variety has excited great comment. The color is the most beautiful shade of mauve-a very fascinating color. The perfection in form of this variety is one of its greatest features. Award of Merit. 50 cents each.

\section{RECOMMENDED COLLECTION OF SIX OF THE BEST PEONY- FLOWERED DAHLIAS, For $\$ 2.00$ prepaid.} Name

Regular Price Frigola. Glowing red, tipped white, $\$ .50$ H. J. Lovinck. White, blending to lilac.

Hortulanus Budde. Deep red.

Madonna. White, daintily shaded lavender-pink. .

P. W. Jansen, Rosy-salmon Zeppelin. Beautiful mauve..... $\quad .50$

\section{.50} 35 25 


\section{Duplex Dahlias}

This is a much needed classification of a favorite type of Dahlias, now listed by some as Peony-flowered Dahlias and by others as Singles. The flowers are semi-double, with center almost exposed at the opening of the bud, with petals in more than one row, more than twelve petals, and not over three rows. Some have broad rounded petals, others are noticeably twisted and curled. They are very free-flowering, being ideal for cut-flowers.

\section{New Duplex Dahlias for 1920}

This collection of Four New Duplex Dahlias for $\$ 5.00$ prepaid.

OSCEOLA. Alexander's New Seedling. The plants are tall and sturdy growers, producing their blossoms on long stems. In color, a bright carmine, with a ring of golden-yellow at the center. 50 cents each.

BETTY WALKER. Alexander's New Duplex Seedling. One of the most exquisite shades I have seen; flowers are produced in great abundance on long stems. White, daintily overlaid a beautiful rhodamine purple; the general impression being rose and white. Mrs. Frank A. Walker of Stoneham, Mass., admired this new seedling, when it first blossomed, and I am pleased to name it for her. $\$ 2.00$ each.

\section{General List of Duplex Dahlias}

This collection of Six Duplex Dahlias for $\$ 4.00$, prepaid.

FRIGOLIA. While not a particularly large flower, on account of its very striking appearance it is very effective in the garden. It comes quite true to its color, a blood-red petal with a white tip. Fine as a cut flower. Free-flowering. 50 cents each.

MARY HOUGHTON. Alexander's New Fragrant Duplex Dahlia. This introduction has a delicate but well defined pond-lily fragrance. The petals are of the Cactus-Peony type, being long narrow and pointed at the tips. The plants are of excellent habit and bloom freely. The color is a light marrow-purple with a ring of waxy cadmium-yellow around the golden-yellow center, the reverse of petals being a beautiful rhodamine-purple. At most remarkable novelty, $\$ 2.00$ each.

MERRY WIDOW (Lustige Witt-

we.) A general favorite, prized by all, the plants being literally covered with brillint scarlet blossoms throughout the entire season. The plante are dwarf and bushy, a single plant making a very effective showing. 75 cents each.

PHENOMENE. Beautiful French Duplex Dahlia. A very effective and novel variety; having beautiful Cactusshaped florets. The color is an exquisite salmon shade, suffused light amber. 25 cents each.

SATUCKET. Cactus-shaped petals of enormous length, curving inward at the tips. In color, the flowers are scarlet, veined goldenyellow. Flowers borne in great profusion. 50 cents each.
MRS. F. H. SWEETLAND. Alexander's New Duplex Seedling. A very rich, beautiful bright lemon-yellow; reverse of petals overlaid begonia red. The plants are of exceptionally good habit, being strong and robust, and producing their flowers in great abundance, upon good long stems. I can recommend this variety as extra fine for garden purposes, it is so free-flowering. The formation of the flower is quite original, with two to three rows of petals. Named expressly for and with permission of MIrs. F. H. Sweetland of Sea View, Mass. in recognition of her great love for flowers. $\$ 2.00$ each.

DAY STAR A very free-flowering pure white variety, that is most appropriately named, being star shaped, each petal being pointed at the end.
$\mathbf{7 5}$ cents each.

YELLOW TRANSPARENT. New Holland Importation. For hedges or bedding this is the finest Dahlia to my knowledge, it being a mass of flowers from early summer until late fall. The plants are dwarf, and very well branched, giving a continuous profusion of flowers. Some are semidouble, others almost single, and of a most exquisite shade of lemon-yellow. 35 cents each. 


\section{Decorative Dahlias}

The Decorative Dahlia is the pride of all Dahlias, standing out pre-eminently. In the garden the plants are strong, sturdy, vigorous growers, with heavy, dark green foliage, and a remarkable constitution. The blossoms are produced in great profusion, which is exceptional for a type of giant-flowering Dahlias. For cut-flower purposes they are unsurpassed, having long, straight stems of wiry stiffness, and producing their flowers in a pleasing upright manner; then principally their lasting qualities when cut-they are unequaled, lasting longer than any of the other types. As an exhibition flower the Decorative Dahlia is the most gigantic of all Dahlias blossoms having beauty, substance, quality-all essential characteristics of a true "Model of Perfection." As a decorative flower they are first in every respect; being graceful, adapted to designs, and most artistic.

The blossoms of the Decorative Dahlias are large, flat, but beautiful in shape, and full to the center; the petals are somewhat irregularly situated, long, broad, flat and nearly straight.

\section{New Decorative Dahlias for 1920}

\section{I will ship this collection of Superb Decorative Dahlias prepaid for $\$ 15.00$.}

COPPERFIELD. New Holland Importation. Cinnamon colored with dark center. Well formed flowers on long stiff stems. $\$ 3.00$ each.

MOONBEAM. An immense flower borne on excellent stems, and in color, a clear lemon-yellow. The plant is a sturdy upright grower, producing its gigantic flowers in abundance, making it one of the most desirable. $\$ 2.00$ each.

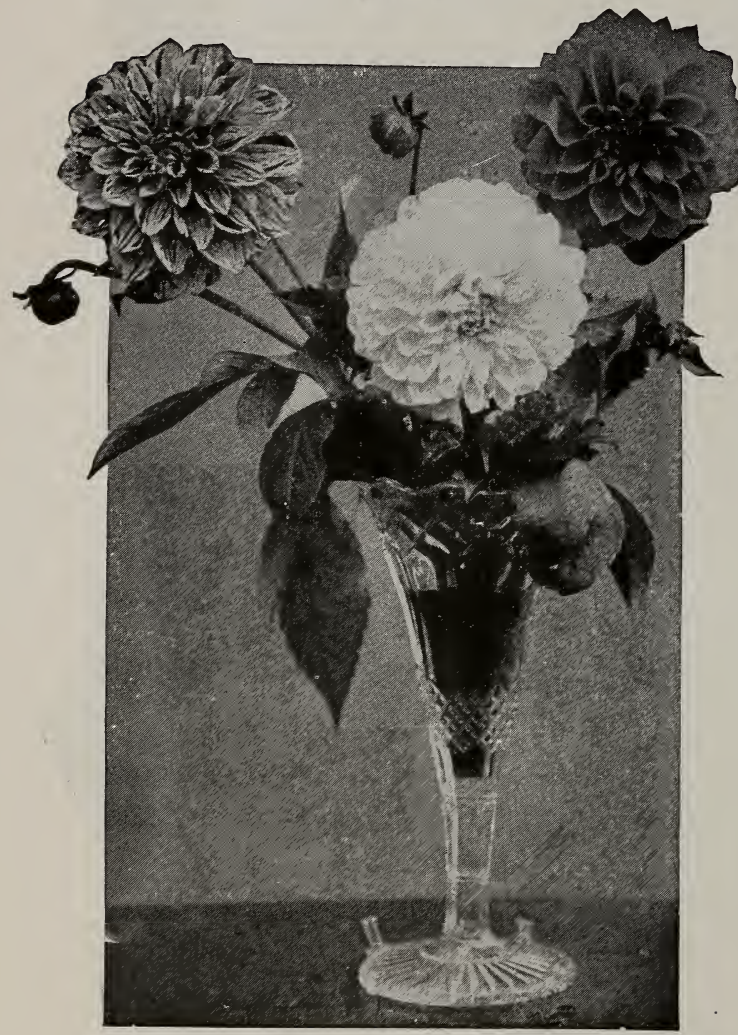

THREE GIANT FLOWERING FRENCH COLOSSAL DAHLIAS, PREPAID FOR $\$ 1.00$.

No. 1 Le Grand Manitou

No. 2 Yellow Colosse No. 3 Madame Marze
JONKHEER BOREEL VAN HOOGELANDEN. A new Holland importation commonly called "Jhr. Boreel." An elegantly formed flower, of gigantic size, and without doubt the finest of its color in existence. The flowers are full to the center, and approaches that of "King of the Autumn" in color, although I consider it afar better Dahlia. A rich deep orange-terra cotta. $\$ 2.00$ each.

DR. TEVIS. A new California creation, that has a long record as a prize winner, commencing with a bronze medal at the Panama-Pacific Exposition, and winning gold medals and first premiums ever since. It is one of the largest and most beautiful Decorative Dahlias; blossoms measuring from eight to eleven inches in diameter, and can be forced larger. The coloring is a beautiful shade of salmon-rose, suffused with old gold, shading to a golden apricot; an unusual blending of colors. The flowers have exceptionally perfect centers, and are produced well above the foliage upon strong stems, making it one of the most desirable. $\$ 2.00$ each.

JANE SELBY. Another new California variety that I take pleasure in recommending, and it too, has captured many gold medals and first premiums. The flowers are of gigantic size; as large as any Dahlia I have grown, and are perfect in shape; coming full to the center, and being of true Decorative type. In color, a beautiful mauve pink; a live but delicate shade, that wins instant favor. The stem is exceptionally good, being long and stiff and the flowers are produced well above the foliage. I can highly recommend this for cut-flower purposes, and for keenest competition. \$2.00 each.

MRS. ELLA CLINE. Alexander's New Decorative Seedling. A beautiful glistening pure white, with good stems, and a Dahlia that has proven an ideal all round variety. It is very free-flowering, and in blossoming qualities and purity of color, it is not surpassed by any white Decorative I have seen. \$2.00 each.

THE MESSENGER. A very good new White Decortive variety, with good habit, and a variety that produces its blossoms well above the foliage. $\$ 1.00$ each.

VELMARY. A gigantic new Decorative Dahlia that I take pleasure in introducing. It is one of the largest and finest dahlias to my knowledge, and possesses one of the most unusual but pleasing combinations of colors I have seen in dahlias. A beautiful primroseyellow, blending to golden-yellow at the center, the whole overlaid a charming shade of orangepink. The habit of the plant is perfect, the plants being strong sturdy vigorous growers and producing their gigantic specimens upon long, stiff stems. $\$ 5.00$ each. 


\section{Up-to-Date Decorative Dahlias}

\section{I will ship this collection of 21 Superb Decorative Dahlias, prepaid, to any part of the United}

BENEDICTUS XV. A very highly recommended variety imported from Holland. The color is a splendid deep vellow, with stiff stems holding the bloom upright and well abore the foliage. One of the latest and best introductions in yellow Dahlias. Highly recommended. $\$ 1.00$ each.

BREEZE LAWN. A grand variety of great prom ise. A perfect exhibition flower, measuring 8 inches and over when properly grown. Color a vivid, fiery vermilion; splendid form, full center and perfect habit free-flowering. $\$ 1.00$ each.

DARLENE. Alexander's Delic a t e New Decora tive Seedling. An exquisite shade of live shell-pink with a dainty blending of white at center. The plants make ideal specimens, averaging about 3 feet in height a single plant making a very effective showing. For massing or hedging, "Darlene" is ideal. The foliage is a heavy, deep green, a perfect contrast with the pink-and-white blossoms. This variety is one of the most satisfactory garden rarieties we are offering, the plants being literally covered with blossoms from early July until frost. The uniformity and perfection of the flowers show unusual qualities. Unquestionably the finest pink-andrhite Decorative Dahlia to date. $\$ 1.00$ each.

DOROTHY FLINT. This is one of the most beautiful rarieties in cultiration. The color combinations are exquisite, being a blending of salmon and pink with a yellow stripe running through the center of the petals. The flowers are from 6 to 7 inche in diameter and are borne on long stems in great abundance, making it valuable for cutting. It is worthy of a place in the most exclusive gardens. $\$ \mathbf{\$ 2 . 0 0}$ each. States or Canada, for $\$ 30.00$.

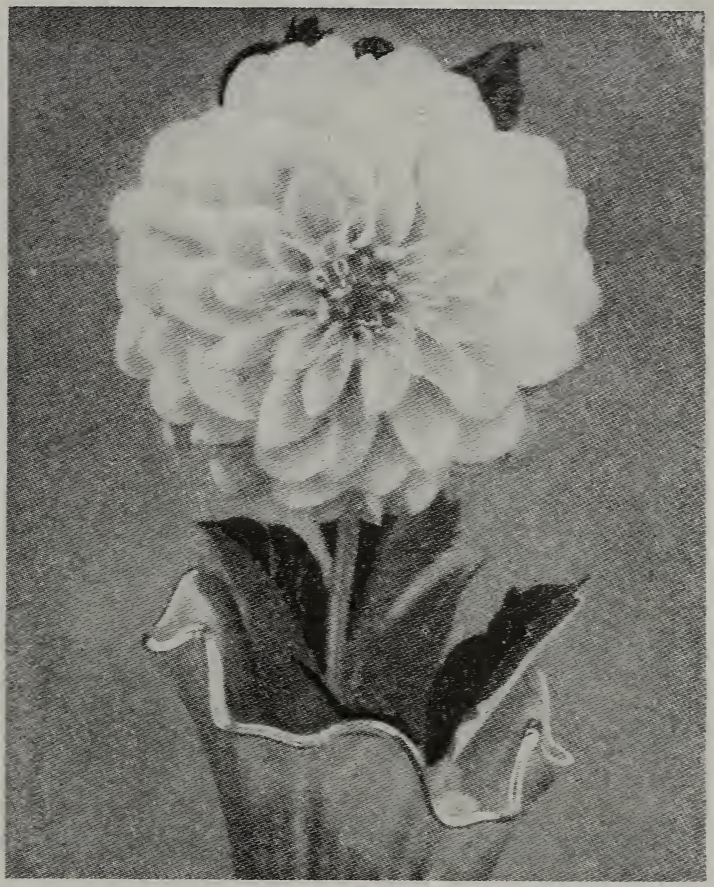

Francis Martin-Decorative Dahlia. (See page below.)

DR. THURMAN. An exquisite combination of coloring, the clear yellow of each petal being rery delicately suffused with copper tints. The plants are tall and sturdy with perfect habit, holding the large flowers to the best possible adrantage. An extra fine Dahlia. \$1.00 each.

EDWARD PARROTT. This variety is different in color from anything else in my entire list, being a beautiful shade of violet-purple. The flowers are very large and are carried well above the foliage on very long, stiff stems. It is a profuse bloomer and ideal for cutting. \$2.00 each.

EVEL YN V. MARSHALL. I regard this Dahlia as one of the most beautiful that I hare ever seen, and if I were compelled to restrict my choice to one variety, this would be my choice without a moment's hesitation. The ground color is white, heavily overlaid with violet-red, showing white tips and edges. The color combinations are similar to those in "Mme. A. Lumiere," but the flowers are three or four times as large. The flowers are variable in color and usually become lighter colored as the season advances. \$3.00 each.

EUGENE BURGLE. An improved seedling from the famous Mina Burgle. A rich, dark red in coloring, the blooms are of immense size and perfect form. The strong, luxuriant plants grow to a height of six feet, and hold the flowers erect and prominent. $\$ 2.50$ each.
FRANCIS MARTIN. One of the most charming new Decoratires and one that will be sure to give perfect satisfaction. A white ground, over-taid lavender, the coloring is somewhat similar to the well-known $\pi$. $\pi$. Rawson, but the shade of lavender is darker. The stems are long and very stiff holding the large flower erect with ease. A good bloomer and ideal for cut flowers. \$2.00 each.

H. MAIER. A very large California production of the greatest merit. Of a shade a little darker than primrose-yellow, each petal is slightly flecked carmine. It is a strong grower, profuse bloomer. and holds the flowers on long. stiff stems. A very fine yellow Decorative. $\$ 2.00$ each.

JENNIE FAULKNER. One of the most distinctive medium-sized varieties in the list and a beauty. It is an intense reddish-peach color, shading to yellow at base of petals and showing a silvery reflex on the edges. It is impossible to describe the color combinations and tints accurately. They must be seen to be appreciated. It is a splendid bloomer. $\$ 2.00$ each.

KING OF THE AUTUMN. One of the finest Decorative Dahlias ever introduced. The habit is absolutely perfect, with strong, sturdy stalks. long, stiff stems and remarkably free-flowering: The coloring is something quite new and unique buff yellow suffused terra cotta. Obtaining several First-class Certificates in Holland, this Dahlia is destined to become one of the most pnpular varieties ever introduced. $\$ 1.00$ each. 


\section{J. K. Alexander, E. Bridgewater, Massachusetts E. Bridgewater Dahlia Gardens}

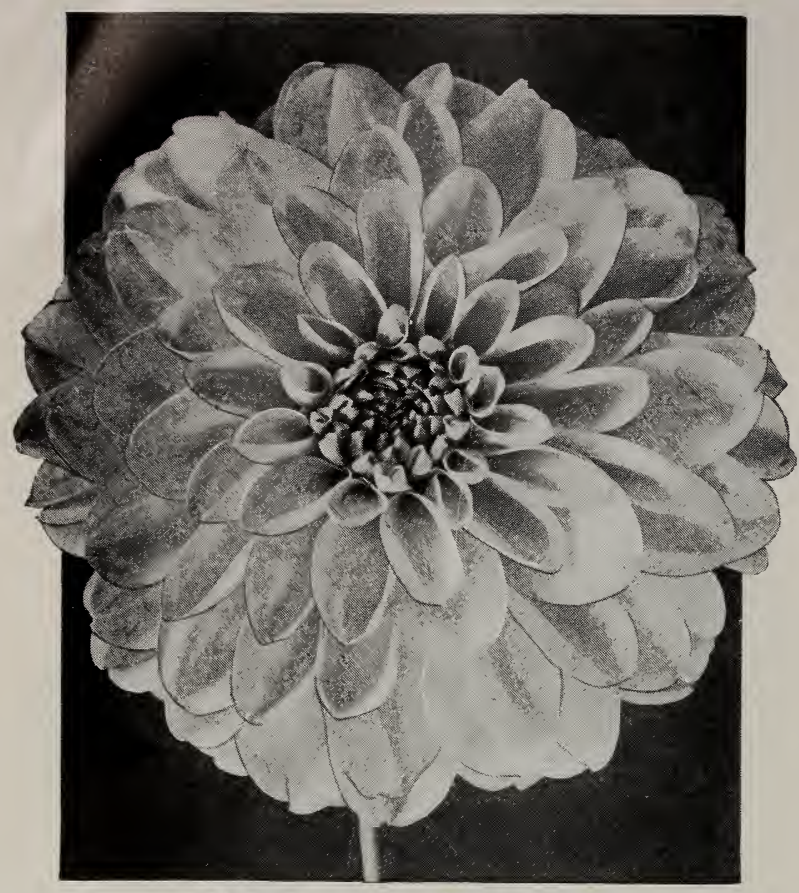

Frank A. Walker. 50 cen ts each.

LEO XIII. The habit of this plant is all that can be desired, producing large flowers upon splendid stems. well above the foliage. "Leo XIII" is a beautiful deep yellow. $\$ 1.00$ each.

LYDIA VANCE. A new Decorative variety of perfect habit and a remarkable blending of colors-white daintily overlaid lavender-pink. One of the finest. \$1.00 each.

MR. TYNDALL. Gigantic new Decorative Dahlia possessing a nove combination of colors-orange yellow heavily shaded bronze. Flowers produced with freedom; stiff wiry stems. $\$ 1.00$ each.

MRS. WM. H. PEPIN. One of the best white Decoratives in existence. This is the largest white Decorative I have ever seen and the finest in form. It is greatly superior in both size and form to the justly celebrated "Mme. Marze." which has for several years been regarded as the best white in this class. As an exhibition flower it is a winner every time. $\$ 1.00$ each.

NOIR ALVAREZ. A gigantic new variety which I can highly recommend. Color, a deep, velvety exblood red. The plants make a sturdy. vigorous growth with long, stiff stems. A profuse bloomer. $\$ 2.00$ each.

RED TANAGER. The brightest and most dazzling red imaginable. This variety stands the hot sun the best and holds its color the longest of any Dahlia of its color I have ever grown. Nothing can excel its brilliancy. \$2.00 each.

SEA GULL. This Dahlia is pure white and is of the largest size. It sometimes comes semi-double and is greatly admired as a Peony-flowered Dahlia. $\$ 2.00$ each.

TENOR ALVAREZ. Gigantic New French Decorative Dahlia. This new variety is one of the largest and finest Decorative Dahlias to my knowledge. The flowers are produced upon long, wiry stems, well above the foliage, which is remarkable for a Dahlia so large. The color combination is very pleasing and attractive but difficult to describeviolet-red very heavily striped and splashed lilac and white. $\$ 1.00$ each.
WM. STARK SMITH. Alexander's Phenomenal New Decorative Seedling. Named expressly for and by special permission of Wm. Stark Smith, Esq., and lover. The plant is a very vigorous grower, with heavy, dark, glossy green foliage and a remarkable constitution. The flowers are enormous, and produced upon stiff, wiry stems, well above the foliage. This wonderful new Fancy Decorative Dahlia is one of the largest Dahlias in existence; a most sensational variety, possessing remarkable qualities. The blossom is perfect in form, grand in appearance, of immense size, and exceedingly wonderful color combination. A beautiful golden-yellow artistically striped and splashed scarlet. The effect of these phenomenal flowers is most pleasing. $\$ \mathbf{\$ 3 . 0 0}$ each.

\section{General List of Decorative Dahlias}

\section{I will ship this collection of 39 Decorative Dahlias, prepaid, to any part of} the United States for $\$ 11.00$.

CLARABEL. Color, rich, rosy purple. 15 cents each.

CLIFFORD W. BRUTON. A large canary-yellow. 15 cents each.

DELICE. The finest and brightest pink Decorative Dahlia in existence. Flowers are of good size, standing well above the foliage. A charming bright pink, suffused with lavender-pink. One of the best known cut-flower varieties in the Dahlia world. 25 cents each.

DOLLY or SYLVIA. White edged pink. 15 cents each.
EASTON. Not extra large, but a variety of brilliant color, good form and remarkable free-flowering habit. In color, a brilliant Turkish red. 25 cents each.

ELSIE DAVIDSON. A beautiful deep, golden yellow, very large, and fine for cutting. 25 cents each.

F. GRINSTEAD. The flowers are of perfect Decorative type and a most artistic combination in colordeep golden yellow, distinctly striped and splashed a clear and effective scarlet crimson. 35 cents each. 
FRANK A. WALKER. Alexander's Decorative Seedling. Expressly named for Mr. Frank $A$. Walker, of Stoneham, Mass., in compliment to his intense love of Dahlias. A charming shade of deep lavender-pink. For garden decoration or for eut flowers this variety is exceptionally good, having long stems and producing flowers in great abundance. This Dahlia should be in every garden. 50 cents each.

FREDERICK SPITTEL. Color, vermilion-scarlet, often tipped white. 25 cents each.

FREEDOM. One of my 1913 Seedling Decorative Dahlias and a variety which will give perfect satisfaction. The flowers are a beautiful deep crimson color and are produced with such ease and freedom that we chose "Freedom" as the most appropriate name. One of the earliest flowering. 50 cents.

GOLDEN WEST. Classed by some as a Show Dahlia, it is really a Decorative with deeply serrated petals. Afine, large flower of pure yellow, on long stems. Very free. 50 cents each.

HORTULANUS FIET. Wonderful New Holland Decorative Dahlia. The coloring of this variety is exceedingly wonderful-a beautiful shade of salmon exquisitely blending to yellow at the center. 75 cents each.

HORTULANUS WITTE. Remarkable New Holland Decorative Dahlia. A perfect wonder. Its remarkable qualities are excellent type, perfect form, and purity of color. The flowers are borne in a miraculous profusion upon long. stiff stems, well above the foliage. The color is a $\mathrm{waxy}$, almost glistening pure white: a beauty in every sense of the word. 50 cents each.

JACK ROSE. The identical shade of the rose with the same name. This variety is exceedingly free, carrying fairly large flowers on very erect stems in great abundance; flowers early, and during the hot weather the color is likely to burn somewhat 25 cents each.

JKANNE CHARMET. The flowers measure from 7 to 10 inches in diameter and are borne on stiff, wiry stems frequently 18 to 24 inches long. The color is a most exquisite shade of lilac-pink, daintily. shading to pure white towards the center, with a tinge of light yellow at the margins. 25 cents each.

JOHN R. BALDWIN. A splendid rariety. Color. a beautiful salmon-red. 25 cents each.

J. M. GOODRICH. Gigantic New Decorative Seedlind. For all purposes, without exception this is the best Decorative we have had the pleasure of introducing. It has size and beauty, exceptionally long stems and is free-flowering. The coloring is entirely new and wins instant faror. A beautiful salmon-pink, each petal effectirely tipped primrose-yellow. The nearest to an ideal Dahlia we have been able to introduce. 50 cents each.

LE GRAND MANITOU. The color of this superb variety is pure white artistically striped, splashed and blotehed deep violet-purple. The plants occasionally bear a solid purple-colored flower. The effect of these phenomenal flowers is most pleasing, giving this rariety a supreme place in this class. 35 cents each.

MADEMOISELLE MARIE HOSTE. A fascinating shade of heliotrope, shaded white. 25 cents each.

MANITOU. Immense flowers of an exquisite amber bronze. 35 cents each.

MELODY. A clear canary-vellow, tipped white. High center with reflexed outer petals. A remarkably free bloomer. 25 cents each.

MINA BURGLE. (See illustration on page 1). A seedling named and originated by Mr. Burgle, a California Dahlia lover. This new introduction is one of the finest varieties to date-a champion variety, producing flowers of gigantic size and remarkable beauty; the best in existence. Color, a glowing and most brilliant scarlet. The flowers are of perfect Decorative type and are borne upon long, wiry stems well above the foliage. Attracts universal attention. 25 cents each.

MINOS. (See illustration on page 42). One of the finest Dahlias to date. Flowers are large and exceedingly beautiful, borne on long, graceful, wiry stems. The color is intense velvety maroon, almost black. An ideal cut-flower variety. Fine for all uses. 25 cents each.

MME. VAN DEN DAELE. A grand Dahlia of highest Decorative type. Flowers are large and of fine form; produced upon exceptionally good stems, well above the foliage. As a cut-flower variety it is unsurpassed. The color is white, deeply edged live silvery-pink. A Dahlia which bears $\mathrm{my}$ highest recommendation. 25 cents each.

MME. VICTOR VASSIER. The grandest, clear sulphur-yellow Decorative to date. 35 cents each.

MOONLIGHT. Color, yellow, petals tipped peach pink. A good flower and good bloomer. \$1.00 each.

MRS. HARTONG. Deep orange, tipped pinkish white. 20 cents each.

OREGON BEAUTY. Originated by an Oregon seed firm. A seedling from "Wm. Agnew," resembling the parent in size, shape and color. Flowers are large and full to the center. Color, a glowing, fiery scarlet. 50 cents each.

PAPA CHARMET. A very brilliant, deep coralred, overlaid with a darker shade of velvety maroon. Very free-flowering. The plant is a vigorous grower, with heavy, dark, glossy green foliage and a remarkable constitution. The general color effect being a rich crimson-maroon. 35 cents each.

PRINCESS JULIANA. Splendid New Holland Decorative Dahlia. It is perfect as an exhibition flower, ideal for garden decoration and unsurpassed for cutting. Holland Dahlia specialists claim this the finest white Decorative Dahlia for cut-flower purposes, and also the best flowering. Received the Holland Dahlia Society's FirstClass Certificate. 50 cents each.

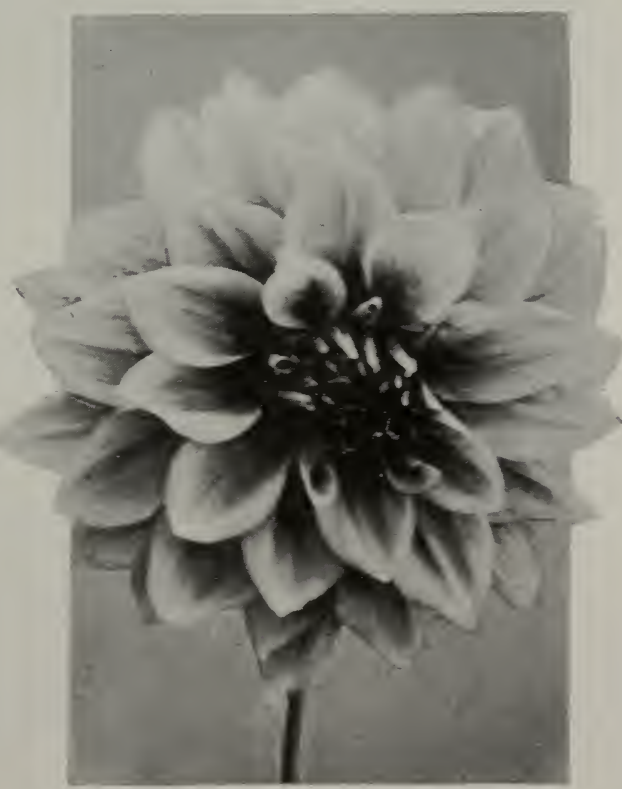

Hortulanus Fiet, (For description. see page 27) 


\section{GENERAL LIST OF DECORATIVE DAHLIAS-Continued.}

PERLE DU PARC DE LA TETE D'OR. One of the best white Decorative Dahlias, resembling the Peony. Petals are evenly split or nicked at the tips, giving the flower an unique appearance. Color, white, effectively overlaid lavender. 25 cents each.

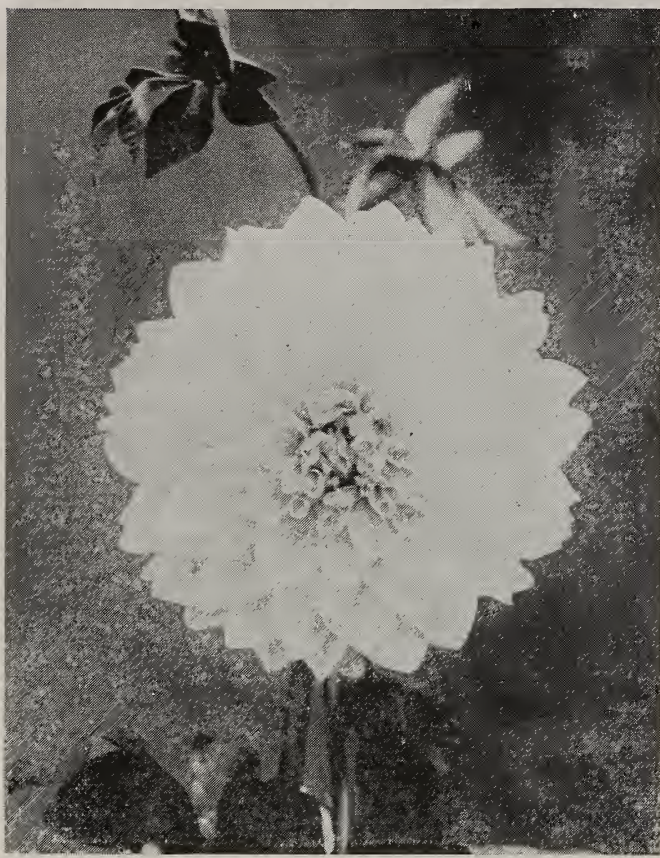

Mrs . Wm. H. Pepin-Decorative Dahlia. \$2.50 each. (See page 26).

\section{RECOMMENDED COLLECTION OF SIX NEW UP-TO-DATE DECORATIVE DAHLIAS for $\$ 10.00$ prepaid.}

I highly recommend these. Name Name
Jhr. Boreel. Orange shades.............. Regular Price Mrs. Ella Cline. Pure white. . . . . . . . . $\quad 2.00$ Dr. Thurman. Yellow shade........... 1.00 Eusene Burgle. Dark red.............. 2.50 Francis Martin. Lavender and white........ 2.00 Noir Alvarez. Crimson-maroon........... 2.00
PERLE DE OCEAN. One of the most charming Decorative Dahlias in existence. A clear, waxy white, beautifully crested lemon-yellow, the whole being daintily overlaid clear pink. One of the finest varieties we ever imported from France and one that will give perfect satisfaction. 35 cents each.

PRINCESS VICTORIA LOUISE. In form very similar to Jeanne Charmet. The color is beautiful deep pink, the stems are long, holding the blooms erect. An excellent cutflower variety. 50 cents each.

PURPLE MANITOU. Enormous flowers of a rich, clear, deep purple. Identical in shape, form and size to "Le Grand Manitou." "The very finest purple Decorative Dahlia in existence. I cannot recommend this variety too highly. 35 cents each.

QUEEN AUGUSTA VICTORIA. Good form and pure white in color. 25 cents each.

QUEEN MARY. This is a stronger grower than Delice. A large flower with full, rounded center. The color is a soft shade of pink. 50 cents each.

SOUVENIR DE GUSTAVE DOAZON. This variety is a good comparison to the "Sunflower." It is the largest Dahlia in existence. The color is a pleasing shade of orange-red. Flowers are full to the center and often measure 9 inches and over in diameter; they can be forced to measure over 12 inches. The plant is a very tall, vigorous grower with heavy, dark, glossy green foliage and a remarkable constitution. Very long stems of pleasing, stiff, upright type. Should be in every garden.25 cents each.

VILLE DE NANTES. Brilliant ruby-crimson. distinctly tipped white. A very attractive variety; one that we can recommend to our friends as a most desirable type of the Decorative Dahlia. 25 cents each.

WILHELME MILLER. Very brilliant purple. This is a fine variety of the Decorative type. 20 cents each.

\section{RECOMMENDED COLLECTION OF SIX GHOICE DECORATIVE DAHLIAS For $\$ 2.00$ prepaid.}

An exceptionally good collection. Name

Frank A. Walker. Lavender-pink Regular Price Hortulanus Fiet. Blending of salmon and

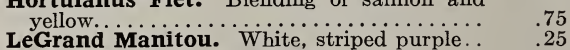
Mademoiselle Marie Hoste. Heliotrope,

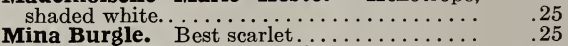
Princess Juliana. Pure white............. $\quad .50$

Mr. J. K. Alexander,

East Bridgewater, Mass.

Box 179A R. D. 4, Murray, Utah, Dec. 29,1919

I was certainly delighted and grateful to receive my lilies, with the Phlox which you added free of charge, and can assure you you have succeeded in your effort to please me.

I'm your friend for life!

I have never been treated so generously before. Your sketch for my shady border was beautiful, and I am going to follow out carefully all its details as soon as Spring comes.

Yours sincerely,

(Signed) Maude Chegwidden.

(Mrs._E.,J._Chegwidden.) 


\section{Giant-Flowering or Colossal Dahlias}

Sincerely believing that there should be a distinction between the "true" flat-petaled Decorative Dahlia and the "hybrid" Decorative Dahlia, of which "Le Colosse is one of the first and best known. I am creating this new classification.

The Colossal type includes all the Giant-flowering Dahlias, intermediate between the broad, flat-petaled Decorative Dahlia, and the common, quilled Show Dahlia.

Colossal fully portrays the idea-gigantic flowers of great depth, massive in proportions, and globular in shape; petals are cup-shaped, and placed in exact regularity. Plants are strong, sturdy and robust.

This phenomenal collection includes the very largest Colossal Dahlias in existence, all exhibition varieties of gigantic size. I will ship the collection of Twenty-four varieties prepaid for $\$ 12.00$.

A. E. JOHNSON. A perfect example of the Giantflowering type. The plants are strong and sturdy, with good habit of growth. The ground color of the bloom is white or light blush, orerlaid with a clear rose-pink. A very large and fine flower. 50 cents each.

AMERICAN BEAUTY. This champion Dahlia is a seedling from the $\pi$ ell-known French rariety, "Le Colosse," being almost identical in form shape and size. The flowers are of gigantic size and are produced on long, heary stems, well above the foliage. The color of this acquisition is a gorgeous wine-crimson. 35 cents each.

CHAS. E. EVERSON. Alexander's New Decorative Seedling. Jamed expressly for Mr. Chas. R. Ererson of Whitman, Mass., a great admirer of beautiful flowers. One of the most exquisite new creations. Color, a clear light lavenderpink, shading to white. Flowers produced upon long stems, well abore the foliage. 75 cents each.

CUBAN GIANT, or DR. J. P. KIRKLAND. Dark relvety crimson; large. Stems long and wiry. Plants are very tall and sturdy. 25 cents each.
FIREBURST. This gigantic Colossal Dahlia is a seedling from the well-known French variety, "Le Colosse." The flower is more flatly built, has broader and longer petals, and is a far more intense scarlet, slightly shaded orange-red. This is a variety of great value, producing specimens which measure 8 inches and over in diameter. The finest scarlet Colossal Dahlia. 50 cents each.

GIANT PURPLE, or ROYAL PURPLE. This new variety is a seedling from "Le Colosse," being identical in form, shape and size. The color is a lively shade of royal purple. The flowers are of perfect formation, very double, and borne on long, miry stems. This is destined to be one of the finest for exhibition purposes. The unusually heavy demand for this rariety leaves ou stock extremely limited. $\mathbf{5 0}$ cents each.

GRAND DUKE ALEXIS. A magnificent floter of large size and distinctly unique form, the petals being so tightly and exquisitely rolled and quilled that the edges overlap each other. The color is a pure white, distinctly tinged pinkish-lavender. 35 cents each.

DREER'S WHITE. An excellent Dahlia for garden effect and hedges; plants are very strong and vigorous, making ideal bushy specimens, averaging 3 feet in height. Color, a pure, glistening white; in form it resembles the popular "Grand Duke Alexis," while in freedom of flowering it is not surpassed by any. Unquestionably the most valuable snow-white rariety in existence. 35 cents each.

D REER;'S YELLOW. A beautiful new Colossal Show Dahlia of perfect form; stems long and straight, carrying the blooms well above the foliage. The flowers form a perfect ball, often measuring 7 to 8 inches in diameter. Color, a rich, sulphur vello $\pi$. $\$ 1.00$ each.

D. M. MOORE. In this offering we have one of the best "nearly black" varie ties to date. It is a rich, deep, velrety Victoria-lake, which is a shade deeper than deep maroon, the nearest approach to black to my knowledge. A mammoth flower produced in profusion on long, stiff stems. 50 cents each.

ESTELLE CHRISTY. One of the best yellow Dahlias of this type ever introduced.

The color is the purest golden-yellow, with no shading whatever. The size, color, length of stem and habit of growth make the above statement no exaggeration whatever. A wonderful flower in erery way. \$2.00 each. 


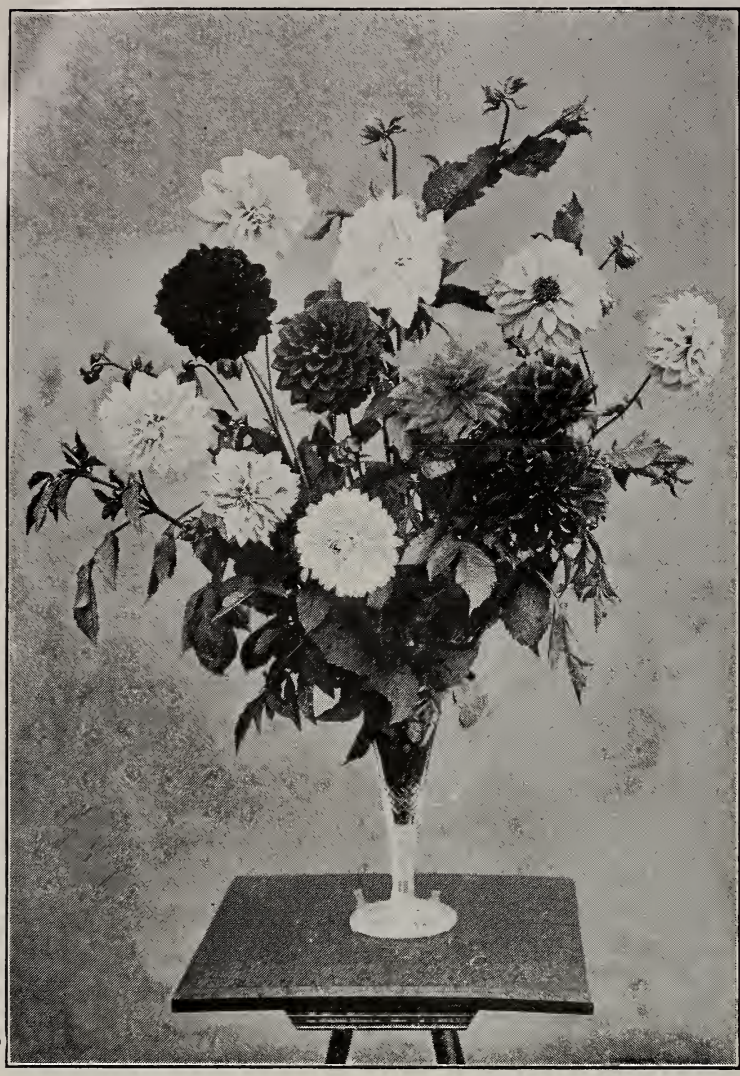

\begin{tabular}{|cc|}
\hline \multicolumn{2}{|c|}{ THIS GRAND, SUPERB SET OF 12 DIFFERENT } \\
DECORATIVES & FOR $\$ 3.00$, PREPAID. \\
No. 1 Jeanne Charmet & No. 7 Jack Rose \\
No. 2 Hortulanus Fiet & No. 8 Wm. Miller \\
No. 3 Frank A. Walker & No. 9 Princess Juliana \\
No. 4 Minos & No. 10 Le Grand Manitou \\
No. 5 Reggie & No. 11 Mina Burgle \\
No. 6 C. W. Bruton & No.12 Souv. de G. Doazon \\
\hline
\end{tabular}

\section{COLOSSAL DAHLIAS-Continued.}

J. K. ALEXANDER. One of my seedlings of special merit which can be highly recommended. It will have a world-wide reputation in a short time because of its excellence and size. This grand Colossal Dahlia is a seedling from the well-known "Le Colosse" and has the exact form of petals and same shape as that famous variety. The color of this beautiful flower is a royal shade of clear, rich violet-purple, which deepens to an exquisite deep purple. The gigantic flowers are borne on long, wiry stems, well above the foliage. This acquisition produces its mammoth flowers freely. \$1.00 each.

LE COLOSSE. An exceptionally popular Dahlia, especially distinguished for its enormous size, being one of the largest grown. Color, brick-red. "Le Colosse" is a very deep, massive flower of globular shape; petals are cup-shaped and placed in exact regularity. One cannot imagine greater perfection. \$1.00 each.

MADAME DEVINAT. In form and arrangement it "Grand Duke Alexis," but it is a great deal larger and deeper. The petals are cupshaped and quilled in the center. The color is pure white, daintily overla id lavender-pink. A very effective variety. \$1.00 each.

MME. MARZE. Ne w French Colossal Dahlia. To our knowledge the grandest white Colossal variety in existence. The perfect form immensity of size and purity of color prove it far superior to any other white Dahlia to date. Its wonderful flowers are produced with exceptional freedom on long, wiry stems. 50 cents each.

MRS. JOHN BOWMAN. Off e red last season for the first time. The form of this flower is out of the ordinary, the center petals being quilled, while the outer ones broaden out to the Decorative type. The color is an exquisite shade of deep, golden yellow, with the reverse of the petals slightly tinged magenta. The stems are long and exceptionally stiff, carrying the large bloom quite free of the foliage. It blooms freely. For an all-round Dahlia it is a valuable addition to its class. $\$ 2.00$ each.

MRS. ROOSEVELT. A most beautiful flower. It is of immense size, fine color, graceful form and has excellent stems for cutting. Flowers are 6 to 8 inches in diameter. Delicate pink, shading to soft pink. 50 cents each.

PURPLE DUKE. This is a new Colossal seedling from that famous French variety, "Grand Duke Alexis.' The petals are cup-shaped and evenly quilled to the center, similar to the parent variety. Color, a rich, deep purple - a royal color that attracts everyone's attention. 50 cen ts each.

REGGIE. A Colossal Dahlia of beautiful cherry - red color. A variety that will give the best of satisfaction, producing flowers upon long stems, well above the foliage. Very free. 25 cents each.

SANTA GRUZ. A remarkably handsome variety of perfect form. The coloring of this variety is exceedingly wonderful - an exquisite deep lemonyellow, artistically overlaid and blending a novel shade of salmon-pink. Exceptionally large and free flowering. The plants are strong and robust, producing their gigantic flowers upon long stems. 75 cents each.

TILLAMOOK. A companion to that grand old Dahlia, Grand Duke Alexis, it differs in color, being a delicate blush, deepening at the tips to Its pleasing color, combined with its rose pink. Its pleasing color, combined with its a prize winner. 35 cents each.

W. W. RAWSON. (See illustration on page 34) The popularity which this novelty has acquired in the short time it has been on the market, speaks for itself for the superior feature of this flower. The petals toward the center are quilled similar to the "Grand Duke Alexis"; toward the outer part they are more open and flat. The color is pure white overlaid with amethyst-blue. This wonderful combination gives it the appearance of delicate lavender. The flowers measure from 7 to 9 inches in diameter. 35 cents each.

YELLOW COLOSSE. An ideal Dahlia that appeals to everyone on account of its distinct color, gigantic size and beautiful appearance. This magnificent yariety is the best exhibition yellow in existence, being rich, refined and delicate. Large, showy flowers of pure primrose-yellow are produced very freely on long, graceful stems. Its golden, cup-shaped petals are daintily arranged, completing this beautiful, perfect flower. 35 cents each.

YELLOW DUKE. A splendid primrose-yellow of good form. 50 cents each. 


\section{Show Dahlias}

\section{New Large Flowering Varieties for 1920}

This Grand Collection of 9 Giant-flowering Show Dahlias are the finest collection of Show Dahlias ever offered in this country; they are introductions from all over the world together with some of the choicest seedlings of this type that I have ever introduced.

I will send this superb collection of 9 Giant-flowering Show Dahlias, prepaid for $\$ 6.00$ cash.

AUGUS MEGAR. New Show Dahlia. The largest and finest lavender-purple Show Dahlia to my knowledge. Tall and sturdy. 75 cents each.

DAVID WARFIELD. Gigantic New Show Dahlia. Beautiful deep cherry-red. A Dahlia of extra good habit, producing its mammoth flowers upon stiff, wiry stems, well above the foliage; a decided acquisition. \$1.00 each.

FLAG OF TRUCE. Sterling New English Show Dahlia. Heralded from England as one of the finest to date. Flowers are perfectly quilled, resembling in form the popular "Grand Duke Alexis." Pure white, effectively tinted violetlavender. 75 cents each.

GOLDEN CROWN. A beautiful new Show Dahlia of exceptional merit. Plants are strong and sturdy with good habit. The color is a deep lemon-yellow, faintly edged with deep strawberry-pink, the whole giving a beautiful golden effect. $\$ 1.00$ each.

MAYOR DUNN. New Show Dahlia. A beautiful, clear scarlet flower of large size and good form. Remarkably free bloomer and very showy. A valuable addition to any garden. 50 cents each.
MAUDE ADAMS. Ideal New Show Dahlia. This wonderful introduction is unsurpassed in quality in every respect; in reality a model of perfection. I cannot speak too highly of this variety. The color is a pure snowy white, very effectively overlaid clear delicate pink. Undoubtedly one of the finest of the Show type. 50 cents each.

MISS HELEN HOLLIS. Gigantic Scarlet Show Dahlia. A sensational wonder and undoubtedly the largest and best deep scarlet Show Dahlia in existence. Blossoms are on long, stiff stems, well above the foliage. Plant extremely sturdy and produces very luxuriant foliage. This acquisition can be highly recommended. $\$ 1.00$ each.

MME. MARIKA ANAGNOSTAKI. The extremely dainty blending of color is remarkable, being snowywhite, delightfully shading to a beautiful rose-pink. 75 cents each.

WALTER HAY. A recent introduction of orangered or reddish-buff, somewhat similar to $W \mathrm{~m}$. Neats, but very much larger. The flowers are of perfect form and are borne on fine, long stems. \$1.00 each.

\section{General List of Show Dahlias}

I will ship this collection of 43 different named varieties, prepaid for $\$ 10.00$.

A. D. LIVONI. Beautiful soft pink. Well formed flowers with long stems. Perfectly round, ballshaped flowers, each petal being very tightly quilled and arranged in exact regularity. Free flowering. 20 cents each.

ACQUISITION. An exquisite shade of deep lilac. Very large with cup-like petals. Especially good for cut-flower purposes. 25 cents each.

ARABELLA. Sulphur-yellow, tipped pinkish-white. 20 cents each.

BERTHA DELAIRE. A beautiful pure white variety of large size; extra fine for cutting. 50 cents each.

DIAMANT. Pure white. 35 cents each.

DOROTHY PEACOCK. The flowers are of good size, exquisite form, great substance; the color is that beautiful, clear, live pink that appeals to everyone. 25 cents each.

DR. KEYNES. Giant Show Dahlia. Buff shaded red. One could not imagine greater perfection in shape. This variety is one of the very best and bears my highest recommendation. 50 cents each.

ELBERTON. A deep orange-red flower. Nothing better in this color. 25 cents each.

EMPRESS OF AUSTRALIA. A very reliable variety. The color is a pure yellow, slightly tipped a reddish-brown. Of good size and habit; free bloomer. 25 cents each.

GLADIATEUR. Clear violet, shaded blue. A splendid new exhibition variety. 35 cents each.

GLOBE DE MANTES. Bright scarlet; a perfect model. 35 cents each.

GOLDEN AGE. Sulphur-yellow. Free-flowering. 20 cents each.

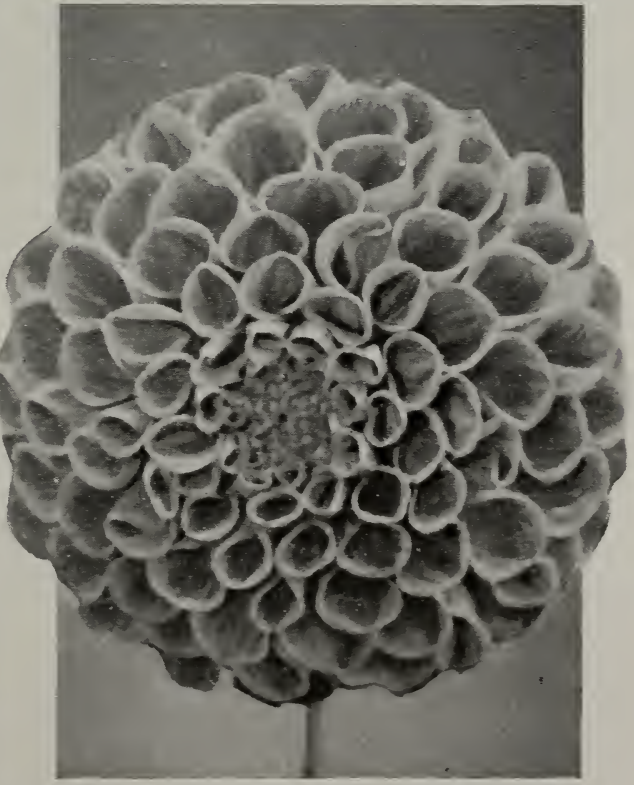

Miss Helen Hollis. (For description see page 31 ). 


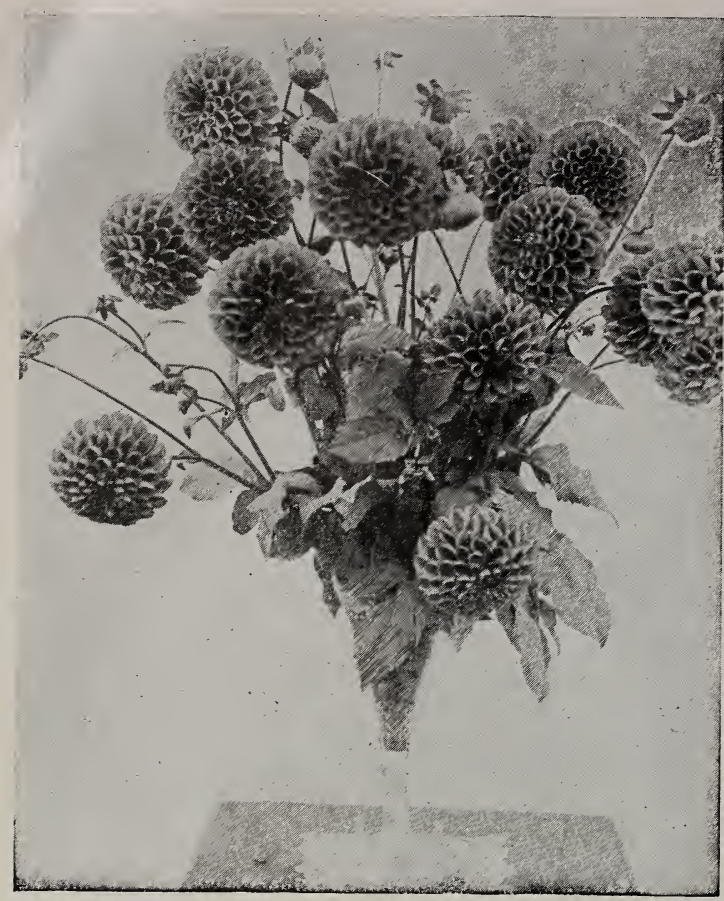

Stradella-Show Dahlia, 20 cents each. Description on page 32)
M. SOMERS. A beautiful clear purple. Large. 20 cents each.

MURIEL. (See illustration below.) A very satisfactory cut-flower variety. The flowers are of good size and are produced upon stems of remarkable length. Color, a most charming shade of orange. 35 cents each.

NORMA. A Dahlia that should be grown by all flower lovers. In my estimation a model of perfection. Flowers are large, perfectly quilled, and of a most exquisite shade of live bright orange. The blossoms are produced in remarkable profusion. 25 cents each.

PRIMROSE DAME. A lovely shade of primrose. Medium size. Free flowering. 20 cents each.

PRINCE BISMARCK. Deep purple. Large, perfect flower of fine form. 20 cents each.

QUEEN VICTORIA, or MARY D. HALLOCK. Canary - yellow. 20 cents each.

REINE CHARLOTTE. Purple with violet tints. 20 cents each.

ROBERT BROOMFIIELD. Pure white. Tall grower. 20 cents each.

ROBERT MANTELL. Deep crimson. One of the very best. 50 cents each.

PERFECTION. Orange-buff shades. This variety is properly named, a true model in every respect. 25 cents each.

\section{SHOW DAHLIAS-Cintiuued.}

HARRISON WEIR. A model in form; fine ballshaped flowers of large size. Color a rich lemonyellow, veined with crimson; good stems. Very free-flowering. 35 cents each.

IMPERIAL. Deep purplish maroon. 20 cents each.

IVANHOE. Beautiful New Show Dahlia. The color combination is exceedingly delicate - a beautiful snowy white, exquisitely edged with pinkishlavender. The flowers are perfectly cupped and especially distinguished for their enormous size. 50 cents each.

JAMES VICK. Purple-crimson. 20 cents each.

JOHN BENNET. Yellow, deeply edged scarlet. A very satisfactory flower. 35 cents each.

LYDIA. An ideal flower; color, vermilion-scarlet. 35 cents each.

MADEMOISELLE LILY LARGE. Clear yellow, striped and speckled vermilion. Very large and a free bloomer; a Dahlia which I can highly recommend. 50 cents each.

MERLIN. A beautiful orange-scarlet. One of the very finest Dahlias ever offered. Free-flowering and good for cut-flower purposes. 25 cents each.

MME. ALFRED MAREAU. This is the finest pink Show Dahlia in existence. Large. 25 cents each.

MRS. LANGRTY. Deep cream, deeply tipped magenta. Long stems and good habit. 25 cents each.

MRS. SUSAN WILSON. This is a grand acquisition to the exhibition class. The color is a deep burnt orange, veined with orange-red. One of the largest. 50 cents each.
MRS. DEXTER. Salmon. 20 cents each.

ROSE. (See illustration herewith.) One of recent introduction; a remarkable Dahlia of decided formation. Color, an exceptionally deep rose shade. Flowers carried erect upon extra long stems. Exceedingly free-flowering. 25 cents each.

RUBENS. Golden yellow with prominent orange center. A distinct flower of unusual beauty. 35 cents each.

STORM KING. The most reliable white Show Dahlia to date. Color, a pure white. Flowers produced on good stems, well above the foliage. Freeflowering. 25 cents each.

STRADELLA. Alexander's Seedling. Beautiful deep purple-crimson. Exceptionally free-flowering. Stems long and wiry. One of the finest to date. 20 cents each.

THOMAS AUSTISS. Deep lilac. Good form. 20 cents each.

VIVIAN. A great favorite which received the admiration of everyone who saw its wonderful flowers the color being white, effectively edged rose-violet. An extremely wonderful blending of color possessed only by the rare novelties. One of our champions of this season's introductions and a variety worthy of the highest words of praise. 25 cents each.

WHITE QUEEN. Pure white with an occasional soft lilac flower on the same plant. 20 cents each.

WHITE SWAN. Pearly white. 20 cents each.

ZEPHORIS. A grand yellow variety. 50 cents each. 


\section{Fancy Dahlias}

I will ship this entire collection of Select Stand ard Fancy Dahlias, 12 Different varieties, for $\$ 3.00$, prepaid.

ARTHUR LEFAVOUR. Gi gantic New Fancy Dahlia. Color a beautiful sulphur-yellow, lined, striped and speckled deep, gorgeous crimson. 35 cents each.

DAZZLER. Deep yellow, striped scarlet. 25 cents each.

FRANK SMITH. Dark maroon, tipped pinkish-white. 25 cents each.

GLOIRE DE GUSCARD. In color it is an almost indescribable combination of orange, red, yellow, pink and white. The appearance of this combination at a little distance is a yellow base, overlaid pinkish red with white tips. 25 cents each.

JOHAN DOEHLER. NeW Fancy Dahlia. A magnificent new variety; buff, striped and speckled crimson. Very large and fine. 35 cents each.

LES AMOURS DE MADAME. NeW Giant Fancy Dahlia. Delicate pale rose, striped scarlet. A beautiful combination of color and universally admired. 50 cents each.

LUCY FAUCETT. Pale yellow, striped deep pink or light magenta. One of the best of this set. Very large and free flowering. 20 cents each.

MARMORATA. The flowers are very large and freely produced. White, finely striped and dotted purple. One of the very best. 35 cents each.

M. AUGUSTA LEMAIRE. Pale yellow, heavily striped maroon. Very odd. Large. 75 cents each.

POLLY SANDALL. A novel combination of bronze-yellow, veined and blotched pinkish white. 25 cents each.

PROF. FAUCETT. Sterling New English Fancy Dahlia. One of the finest of this season's intro ductions. Lilac, beautifully striped chocolate; flowers of gigantic size. 35 cents each.

UNCERTAINTY. A brilliant combination of very light shell pink and scarlet. No two flowers are the same. 20 cents each.

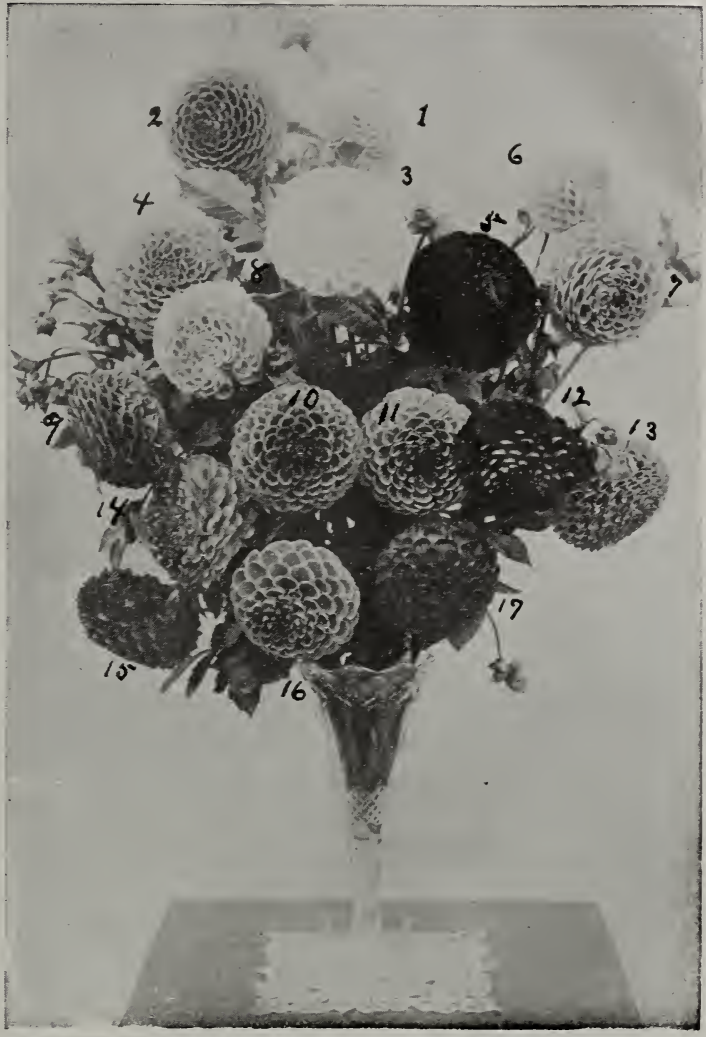

THIS GRAND, SUPER SET OF 17 SHOW AND FANCY DAHLIAS, $\$ 4.00$ PREPAID.

This is the best set of large-flowering Show and Fancy Dahlias ever offered in this country for the money. All prize winners.

No. 1 Primrose Dame No. 10 Diamant

2 Merlin

3 Storm King

“ 4 M. Somers

“ 5 Reine Charlotte

“6 Ivanhoe

“ 7 Empress of Australia

“ 8 Acquisition

“ 9 Vivian
“ 11 Gladiateur

12 Golden Age

13 Lucy Faucett

“ 14 Rose

15 Stradella

" 16 Norma

“ 17 Mrs. Susan Wilson

1477 Waterbury Road, Lakewood, Ohio,

Mr. J. K. Alexander,
East Bridgewater, Mass.

ilay 10, 1919.

Dear Sir,-

The Dahlia bulbs arrived to-day in good condition. I want to thank you for your very prompt service as well as for the ones sent gratis.

I shall follow your worthy suggestions in planting, and am looking forward with a great deal of pleasure for good results. I remain,

Assuring you of continued patronage, providing the bulbs produce the flowers mentioned in your catalog, 


\section{Pompon Dahlias}

The Pompon Dahlias are the finest for cut flowers; they bloom more freely than any of the other classes. The flowers are small, compact, and full to the center, and are produced upon long, wiry stems. Extra fine for bouquets. I have the largest and finest collection of any firm in America and have won more first prizes on this class of Dahlias than any other competitor in the U. S. A.

\section{New Pompon Dahlias for 1920}

Six Ideal Pompon Dahlias for $\$ 2.50$, prepaid.

G.LORIA. Alexander. In this little gem the coloring is absolutely unique. A beautiful winecrimson, blotehed pinkish white. Very free-flowering. 75 cents each.

LEADER. Alexander's New Pompon Seedling. An exceedingly neat, compact flower; of perfect form. The color combination is remarkablea clear, lemon-yellow, very heavily tipped rosypurple. An entirely new color. One of the best in existence. 50 cents each.

LITTLE DOROTHY. Alexander. White, occasionally striped and boltched reddish-orange. Exceptionally free-flowering. 35 cents each.

PRIDE. Alexander's New Pompon Seedling. Very deep crimson-scarlet. A model of perfection in shape. 25 cents each.

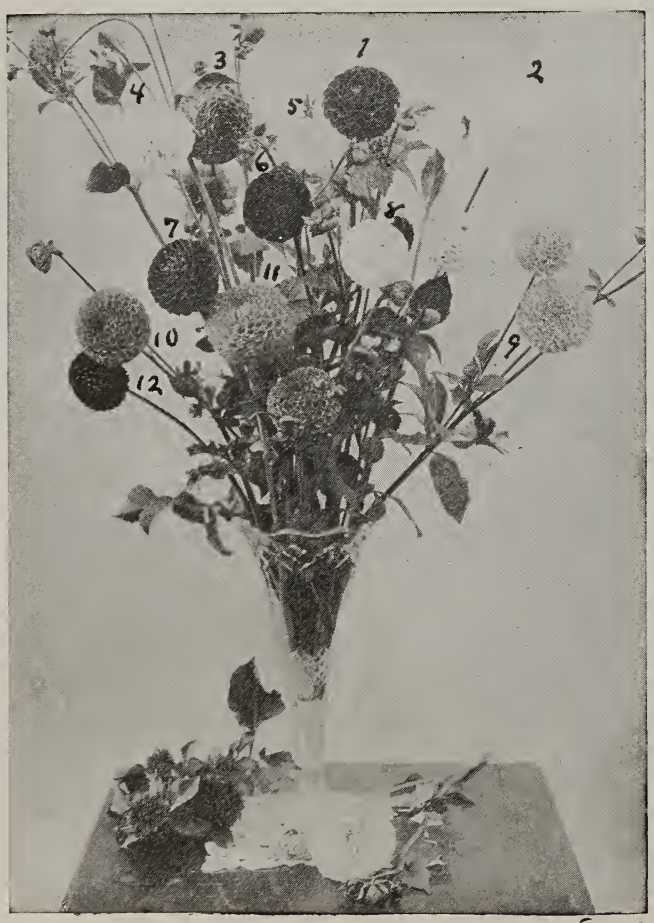

THIS GRAND, SUPERB SET OF 12 POMPON DAHLIAS, PREPAID, $\$ 2.00$.

No. 1 Pride

No. 2 Snowclad No. 3 Madeline No. 4 Zoe

No. 5 Golden Queen No. 6 Darkness
SPY. Alexander. Undoubtedly the best orangescarlet exhibition variety in existence. 50 cents each.

GOLDEN QUEEN. Alexander. The most perfect yellow Pompon to date. 50 cents each.

\section{General List of Pompon Dahlias}

This collection of select Pompon Dahlias, 2) cents each, $\$ 2.00$ per dozen, unless otherwise priced; or I will send the 33 different varieties for $\$ 5.00$.

ALEWINE. Delicate pink, tinted lilac. Fine. 20 cents each.

AMBER QUEEN. Rich, clear amber, shaded apricot. 20 cents each.

ARIEL. Orange-buff. 20 cents each.

BELLE OF' SPRINGF'IELD. The smallest Dahlia grown. Perfect miniature flowers of bright brick red. A little beauty. 25 cents each.

BOBBY. Plum color. One of the best. 20 cents each.

BRUNETTE. Crimson, sporting white. 20 each.

CATHERINE. Bright yellow. 20 cents each.

DARKEST OF ALL. Nearly black. Best dark Pompon Dahlia. 20 cents each.

DARKNESS. Dark maroon. 20 cents each.

DARKSOME. Alexander. The color is a deep wine-crimson, almost maroon. Fine form with long, graceful stems. 50 cents each.

DONOVAN. White with lavender tips. Very fine. 20 cents each.

ELFIN. Beautiful primrose-yellow. 20 cents each.

FAIRY QUEEN. Sulphur-yellow, edged pink. 20 cents each.

FASCINATION. Pink and lavender, blotched white. 20 cents each.

GRAUSS AM WEIN. Crushed strawberry. 20 cents each.

H. C. WINTERS. Pale fawn. 20 cents each.

HENRIETTA. Yellow, tipped crimson. 20 cents each.

JESSICA. Yellow, edged red; a very effective combination. 20 cents each.

JEWELL. Ideal New Pompon Dahlia. An exquisite bright yellow, tipped, striped and blotched pure white. 35 cents each.

LITTLE BEAUTY. A very beautiful light pink. Small. 25 cents each.

LITTLE MARION. Alexander's Ideal New Pompon Seedling. The ground color is a soft salmon-pink with a veining of crimson through each petal and effectively tipped with a light reddish amber. 35 cents each. 


\section{POMPON DAHLIAS-Continued}

LITTLE BELLE. A clear, rosy-pink throughout. 25 cents each.

LITTLE MARY. Dark crimson. A perfect model in every way. 35 cents each.

MADELINE. Pale primrose, edged with rosepurple. Very free flowering. 20 cents each.

MARLIENE. A new seedling of our introduction. This is a grand addition to the Pompon class: dwarf branching habit with fine compact flowers full to the center. The color is a deep purple. 50 cents each.

AY CLIFT. Light maroon. 20 cents each.

PHOEBE. Orange, tipped crimson. 20 cents each.
RUY BLAS. Crimson and purple, tipped with white. 35 cents each.

SAN TOY. White, very heavily tipped carmine. 20 cents each.

SNOW CLAD. Small white. Free. 20 cents each.

SUNBEAM. Crimson-scarlet; extra fine. 20 cents each.

SUNN Y DA YBREAK. Pale apricot, edged rosy-red. 25 cents each.

ZOE. Base of petals edged clear yellow, tips white Sometimes blossoms come all yellow. 20 cents each.

\section{Some of the Premiums I Won in Open Competition During the year 1919}

At Annual Iris Exhibition of Massachusetts Horticultural Society, held June 7-8, 1919, in Horticultural Hall, Boston.

1st Prize for Best 12 vases of Iris Germanica.

Vote of Thanks for Special Display of Irises.

At the Annual Peony Exhibition of Massachusetts Horticultural Society, held June 15th in Horticultural Hall, Boston.

Silver Medal for Display of Peonies.

At Annual Exhibition of North Shore Horticultural Society, held August 6 and 7,1919 , at Manchester-bythe sea, Mass.

Silver Medal for Largest and best Exhibit of Dahlias. Silver Medal for Finest Display of named Gladioli. Silver Medal for Largest and finest Display of Phlox. Certificate of Merit for New Seedling Decorative Dahlia "Frank A. Walker."

At the Annual Gladioli and Phlox Exhibition of the Massachusetts Horticultural Society, held Aug. 9 and 10, 1919, in Horticultural Hall, Boston.

Silver Medal, highest award for Display of Gladioli, Phlox and Dahlias.

At the Annual Exhibition of Marshfield Agricultural \& Horticultural Society, Marshfield, Mass., held Aug. $19-21,1919$.

Gold Medal for Finest Display of Dahlias.

Gold Medal for Best Collection of Gladioli.

1st Premium for Best Exhibit of Cactus Dahlias.

1st Premium for Largest Display of Perennial Phlox.

At the Annual Exhibition of the Barnstable Agricultural Society, held Aug. 26-28, 1919, at Barnstable, Mass.

1st Prize for Largest and Best Display of Gladioli.

1st Prize for Most Artistic Vase of Gladioli.

2nd Prize for Display of Dahlias.

At the Annual Exhibition of the Agricultural Society of the United Shoe Machinery Co., held August, 1919, at Beverly, Mass.

Gold Medal for Largest and Best Display of Dahlias . Gladioli, Phlox and other Perennials.

At the Connecticut State Fair, held Sept. 1-5, 1919, at Hartford, Connecticut.

1st Premium for Best Collection of Perennial Phlox. 1st Premium for Best 12 Peony-flowered Dahlias.

At the Horticultural and Agricultural Fair of Brookville Grange, held in Brookville, Mass.

1st prize for Display of Dahlias and Gladioli.
At the Annual New England Fair, held Sept. 1-4, 1919, in Worcester, MIass.

Silver Cup for Largest and Finest Display of Dahlias. 1st Prize Best Exhibition of Dahlias.

1st Prize for Best 20 Cactus Dahlias.

1st Prize for Best Collection of all Large-flowered Dahlias, except Cactus Dahlias.

1st Prize for Finest Collection of Pompon Dahlias.

At the Annual Exhibition of the Weymouth Agricultural and Industrial Society, held in Sept., 1919, at Weymouth, Mass.

1st Premium for Best Display Dahlias.

1st Premium for Finest Exhibit of named Gladioli.

At the Annual Exhibition of the Plymouth County Agricultural Society, held Sept., 1919, in Bridgewater. Mass.

1st Prize for Finest Display of Dahlias.

1st Prize for Largest Exhibit of Gladioli.

1st Prize for Largest and Best Display of Flowers, which included many Hardy Perennials.

At the Annual Dahlia Exhibition of the Massachusetts Horticultural Society, held Sept. 11-14, in Horticultural Hall, Boston.

Silver Medal, the Highest Award for Finest Display of Dahlias and Gladioli.

1st Prize for Best Collection of 12 Peony-flowered Dahlias.

Honorable Mention for Seedling Peony-flowered Dahlia "Miss Lymena T. Baxter."

Honorable Mention for Seedling Decorative Dahlia "Wm. Stark Smith."

Honorable Mention for Seedling Peony-flowered Dahlia "Lavender Beauty."

At the Annual Exhibition of the Rockland Horticultural Society and Rockland Grange, held Sept. $24-25$ in Rockland, Mass.

1st Premium for Finest Display of Dahlias.

1st Prize for Most Beautiful Exhibit of Gladiloi.

At the Annual Brockton Fair, held Oct. 3-6, 1919, in Brockton, Mass.

1st Premium for Best 25 Cactus Dahlias.

1st Prize for Finest Display of Show and Fancy Dahlias.

1st Premium for Best Display of Single Dahlias.

Gratuity as a special award for the Largest Display of Dahlias. 


\section{Single Dahlias}

These have become extremely popular, and we really think they deserve it, for they are pleasing and most graceful. Every variety is very free-flower ing, and beautiful for the garden. These effective varieties are making wonderful progress among the flower-loving public, because they have grace, simplicity, and beauty to make their form liked. Their flowers appear early and late in a miraculous profusion; this makes an ideal garden Dahlia Their colors are all rich, refined and delicate, and as a decorative flower for the garden or home, they have no rival.

\section{New Single Dahlias for 1920}

One Each of these Six Superb Single Dahlias, prepaid for $\$ 3.00$.

HIAWATHA. Alexander's New Giant Single Seedling. This remarkable new variety is the largest of my new seedings. The plant is tall, sturdy, of pleasing upright growth, and a gorgeous dark, velvety maroon in color. One of the most satisfactory Single Dahlias. 50 cents each.

MARGARET PERKINS. Pure white with about one-half of each petal tipped with bright cerisepink, becoming a clear cerise-pink late in the season. Very large and a fine bloomer. A high class flower. 50 cents each.

NIPINITIC. Alexander's New Single Seedling. A very large purple-crimson flower, produced in great profusion upon tall sturdy plants. 75 cents each.
SACHEM. Alexander's New Single Seedling. A beautiful orange-scarlet. Flowers of large size. 50 cents each.

SPLASHED BEAUTY. Alexander's New Single Seedling. Bright golden-yellow thickly splashed rich crimson. A long stemmed variety, producing its flowers in abundance. 50 cents each.

SURPRISE. New Single Dahlia. A striking and sensational flower. The color is a brilliant carmine with a lemon-chrome ring at the center, the whole being striped and splashed deep ox-blood red. Flowers of large size. 50 cents each.

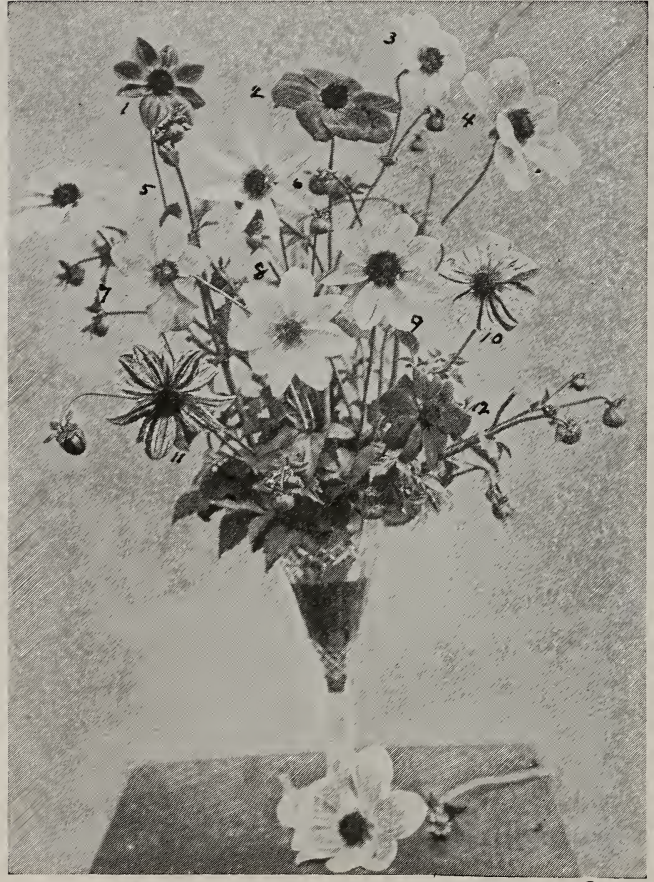

TWELVE IDEAL SINGLE DAHLIAS, PREPAID $\$ 2.00$.

No. 1 Thomas Becket

No. 2 Wildfire Century

No. 3 Blanche

No. 4 Twentieth Century

No. 5 Rose-pink Century

No. 6 Empress

\section{General List of Single Dahlias}

This entire collection of 42 varieties $\$ 9.00$ prepaid.

ADVENTURE. A most pleasing shade of pinkish crimson, striped and splashed maroon. 20 cents each.

AEROPLANE. Up-to-date Single Dahlia. One of the most distinguished of this collection, being an exceedingly brilliant crimson. 20 cents each.

ALVA. One of the most beautiful of the striped varieties. Yellow, speckled and tipped with pink. 20 cents each.

AMI BARILLET. The maroon or purple foliage Dahlia. Color, richest garnet. 20 cents each.

ATTRACTION. Brick-red petals, occasionally suffused wyellow. Yellow dise in center. 25 cents each.

AUBRIGHT BEAUTY. A seedling named and originated by one of my customers and through his kindness I have the pleasure of introducing it. A pure, waxy white variety. 35 cents each.

BEAUTY'S MASK. Alexander's Wonderful New Giant Single seedling. This new Dahlia is the finest of our Single Seedlings, producing admirably gigantic specimens, measuring 5 inches and over in diameter. The blossoms are perfect beauties-a wonderfully rich, clear purple. One of the choicest varieties in existence. 75 cents each.

BLANCHE. (See illustration on page 7.) The flowers are large and very attractive, being a pale yellow at the base, faintly tipped pink with a cast of pure white over the whole flower, making it one of the most delicate varieties to date. 20 cents each.

GARDINAL GENTURY. Rich cardinal. One of the best in form and color. 20 cents each.

DAUNTLESS. Alternating in color from silvery-pink to deep rose and elegantly striped crimson-maroon. 25 cents each.

DELICATISSIMA. White, tinged pink. 25 cents each. 


\section{SINGLE DAHLIAS.-Continued.}

ECKFORD CENTURY. One of the largest of the single varieties. Pure white, streaked and dotted purple-crimson. 50 cents each.

ELINOR. This charming new seedling is one of the finest Single Dahlias in existence and is destined to become, by virtue of genuine merit, one of the most popular. The color is a delightful yellow, heavily tipped a light shade of crushed strawberry. 25 cents each.

ELMWOOD. An unusually fine variety which is greatly admired by all who like striped Dahlias; color, a beautiful pinkish-crimson, striped, splashed and blotched mahogany. 20 cents each.

EMPRESS. A lovely shade of rose-pink; large and beautiful. 25 cents each.

FEDORA. Large. Color, bright yellow heavily tipped bright red. 25 cents each.

G. E. VARNUM. Deep red, tipped lighter, 20 cents each.

FLORENCE DARE. Deep rose-pnk, with a purplish tinge, striped crimson. A large flower with long, rather narrow petals, slightly twisted. 35 cents each.

GLOWING GEM. A splendid flower with perfectly gorgeous coloring, being rich, deep crimson. 25 cents each.

GRACIE. Delicate blush-pink; a fine bloomer. 25 cents each.

JENNIE WREN. White, effectively striped and splashed deep purple. 20 cents each.

JOHN COWAN. Soft crimson, shaded maroon. 25 cents each.

MR. FRANK I. SHOREY. The coloring is most fascinating and delightful, being a beautiful waxy white, effectively veined and shaded delicate pinkish lavender. 35 cents each.

NEWPORT PRIDE. A large, clear yellow. 25 cents each.

NEWPORT WINNER. A large crimson flower of the best size and form. 25 cents each.

PAINTED BEAUTY. Garnet, striped deep maroon and tipped white. A striking flower. 25 cents each.

PINK BEAUTY. Clear lavender-pink; a most beautiful flower. 25 cents each.

PROSPERITY. Light center, very heavily tipped rose-purple. 20 cents each.

ROSE PINK CENTURY. A rose-pink shade. 20 cents each.

SIREN. Crushed strawberry, crimson and yellow. A beauty. 25 cents each.
SADIE. A pleasing novelty which is very striking and effective. Color, a beautiful pink, neatly striped and speckled maroon. 20 cents each.

SNOWFLAKE. A large flower of the purest white. 50 cents each.

SOUV. DE PARIS. A giant among Single Dahlias. Pure white with long and rather narrow petals. A superb variety. 35 cents each.

ST. GEORGE. A very free-flowering variety of clear yellow. 25 cents each.

STRIPED GEM. Pinkish purple, striped maroon. 25 cents each.

THERIES. White, striped and splashed violet. 20 cents each.

THOMAS BECKET. Crimson lake with bright yellow ring in center. 20 cents each.

TWENTIETH CENTURY. (See illustration on page 39). Purest white at both base and tips and the center of petals is a delicate blush rose. Very large -5 to 7 inches in diameter. 20 cents each.

UTOPIAN. The finest of its color to date-clear purple. 25 cents each.

VICTORY. A brilliant wine-crimson Single seedling of remarkable qualities; a champion variety. 20 cents each.

VIOLETTE. Lively shade of crimson. 20 cents each.

WILDFIRE CENTURY. Brilliant flaming scarlet with orange-red suffusion at base. Unique and pleasing form. 20 cents each.

Mr. J. K. Alexander,

Augusta, Me., Nov. 24, 1917.

East Bridgewater, Mass.

My dear Mr. Alexander:

It's no more than fair that I tell you how much we enjoyed our Dahlias this summer. I had the place prepared in the fall. It was about 18 feet long, beside our piazza. They all grew very stalky and were from 5 to $6 \frac{1}{2}$ feet tall; they were just covered with flowers the entire season. The different types and colors were surprising to us all as well as to our friends and neighbors, and for the amount of money sent you they afforded us more pleasure than any such amount ever sent to any firm sending out bulbs before. Next year I must have some more beauties so send me a catalog as early as possible.

Thanking you for every courtesy shown us and wishing you a most prosperous year, I remain, Very sincerely yours,

C. E. STURTEVANT

\section{RECOMMENDED COLLECTION OF SIX BEST SINGLE DAHLIAS.}

For $\$ 1.00$ prepaid.

Name

Regular Price

Adventure. Crimson, striped maroon..... \& .20

Attraction. Brick-red, suffused yellow.... .25

Jennie Wren. White, striped purple....... .20

Glowing Gem. Rich crimson-red........ .25

Prosperity. Light center, tipped rose-purple. $\quad .20$

Rose-pink Century. Rose-pink

\section{RECOMMENDED COLLECTION OF SIX BEST GIANT-FLOWERING DAHLIAS}

For $\$ 4.00$ prepaid.

Name

Regular Price

Ausus Megar. Lavender-purple......... \& .75

David Warfield. Deep cherry-red........ 1.00

Golden Crown. Yellow, faintly edged..... 1.00

Maude Adams. Pink and white......... 50

Miss Helen Hollis. Deep scarlet......... 1.00

Mme. Marze. Pure white............. .50 


\section{Collarette Dahlias}

French specialists have given us the beautiful improved Colarette Dahlia, an entirely new type of Dahlia, all of which have wonderful flowers and delightful color combinations. These have been shown extensively the last few years at the European Dahlia Shows, where they met with great favor, and we feel confident that they will meet with the same approval here.

The flowers are single, with an additional row of short petals around the disc, which form a frill or collar, usually of a different color from the rest of the flower.

This remarkable collection of 18 Novelty Collarette Dahlias, prepaid for $\$ 6.00$.

VIRGINIA LEE. Alexander's New Collarette Seedling. Named for Miss Virginia Lee Sturgis, and an exceptionally attractive variety, that created considerable comment when used as part of the floral decorations at Miss Sturgis' sister's wedding, where it was effectively displayed. It is a very freeflowering variety, with long stems. In color, a deep velvety carmine, edged sulphur-yellow; collarette, pale sulphur-yellow. 50 cents each.

ACHIEVEMENT, or JOHN L. LINDER. AleXander's Wonderful Collarette Introduction. This phenomenal creation is the largest Collarette Dahlia in existence - a perfect wonder, especially distinguished for its perfection and unsurpassing qualities. The flower is a clear, rich velvety maroon; collarette, a beautiful snowy white, very daintily overlaid with a delicate shade of pinkishcrimson. The remarkable contrast of the above combination of color, together with its ideal form and profusion of flowers, secures for this variety a supreme place in the Dahlia world. 35 cents each.

AMI CHACHET. New French Collarette Dahlia. Orange-red, yellow collarette. 35 cents each.

AMI NONIN. Gigantic New French Collarette Dahlia. Dark crimson-carmine edged with lilac; white collarette. 75 cents each.

COMTE. CHEREMETEFT. Vermilion, shading to orange at tips. The collar is creamy white. 25 cents each.

DIRECTEUR RENE GERARD. Gigantic French Collarette Dahlia. Beautiful violet-purple, shaded and tipped white; white collarette. Exceptionally large flowers produced in great profusion. I recommend this variety very highly. 25 cents each.

\section{EXPOSITION DE LYON. Ideal French Collaret te} Dahlia. A very gay flower of bright garnet, with exceptionally fine yellow tips; white collarette, daintily suffused lavender and overlaid crimson. One of the showiest. 25 cents each.

GALLIA. French Collarette Dahlia. Carminered, edged primrose; sulphur-yellow collarette. $\mathbf{5 0}$ cents each.

JUPITER. New Collarette Dahlia. Primroseyellow, suffused crimson; sulphur-yellow collarette. 35 cents each.

LEUCHTFEUER. Golden yellow, tinged orange-red, with sulphur-yellow collar. Good upright habit. 50 cents each.

MME. GYGAX. Vermilion-red, collar yellow. A very showy variety. 50 cents each.

\section{RECOMMENDED COLLECTION SIX BEST COLLARETTE DAHLIAS. For $\$ 2.00$ prepaid.}

Name

Regular Price

Achievement. Velvety maroon; collar white \$ $\$ .35$

Directeur Rene Gerard. Violet-purple; collar white

Jupiter. Yellow suffused crimson; collar yel-

Meteor. Crimson-maroon; collar white......

Negro. Nearly black; collar white.

Signorina Rosa Esengrini. Orange-scarlet; collar yellow. ....................................
MAURICE RIVOIRE. Wonderful French Collarette Dahlia. (See illustration above.) Of sterling quality. The flowers are produced in great profusion on long, graceful stems, well above the foliage. The flower is a gorgeous, rich crimson with pure white collarette of short, well formed petals, perfectly arranged around the rich golden yellow center. One of the finest novelties. 25 cents each.

METEOR. New Collarette Dahlia. Crimson-maroon, very slightly edged old gold; cream white collarette. Star-shaped. 35 cents each.

MME. E. POIRIER, Attractive New French Collarette Dahlia. An ideal Dahlia that appeals to everyone. This variety is renowned for its excellent qualities, distinct color, perfect form, and beautiful appearance. It possesses a very remarkable coloring, entirely new in the Dahlia world. (The nearest approach to blue.) A beautiful, deep velvety purple, suffused lighter, which gives a violet-blue effect; collarette is a waxy, almost glistening pure white. A very satisfactory variety of unusual merit. We recommend it very highly. 35 vents each.

NEGRO. New Collarette Dahlia. Very dark maroon; white collarette. 75 cents each.

ORPHEE. Superb New Collarette Dahlia. Bright orange-red; golden orange collarette. 50 cents each.

SIGNORINA ROSA ESENGRINI. New French Collarette Dahlia. Lemon-yellow marked with orange-scarlet; lemon-yellow collarette. 35 cents each.

SOUVENIR DE CHABANNE. First-class French Collarette Dahlia. A variety of great merit especially distinguished for its charming coloring and large size. Lemon-yellow with coral-red markings; collarette petals very abundant, lemon-yellow. tipped white. This was one of the first originated and still anks among the best. 25 cents each.

\section{Dahlias Which are Not Catalogued}

If you are looking for varieties that are not catalogued it will pay you to write to me before ordering elsewhere as I carry a large list of un catalogued varieties, my stock being insufficient to warrant me to catalogue these varieties.

\section{RECOMMENDED COLLECTION OF SIX BEST POMPON DAHLIAS,}

For $\$ 2.00$ prepaid.

Name Regular Price

Amber Queen. Apricot............... \$ .15

Darksome. Almost black ............. $\quad .75$

Golden Queen. Clear yellow........... . .50

Leader. Yellow, tipped rosy-purple....... $\quad .50$

Little Belle. Rosy-pink. . . . . . . . . . . . . . .25

Pride. Crimson-scarlet. . . . . . . . . . . .25 


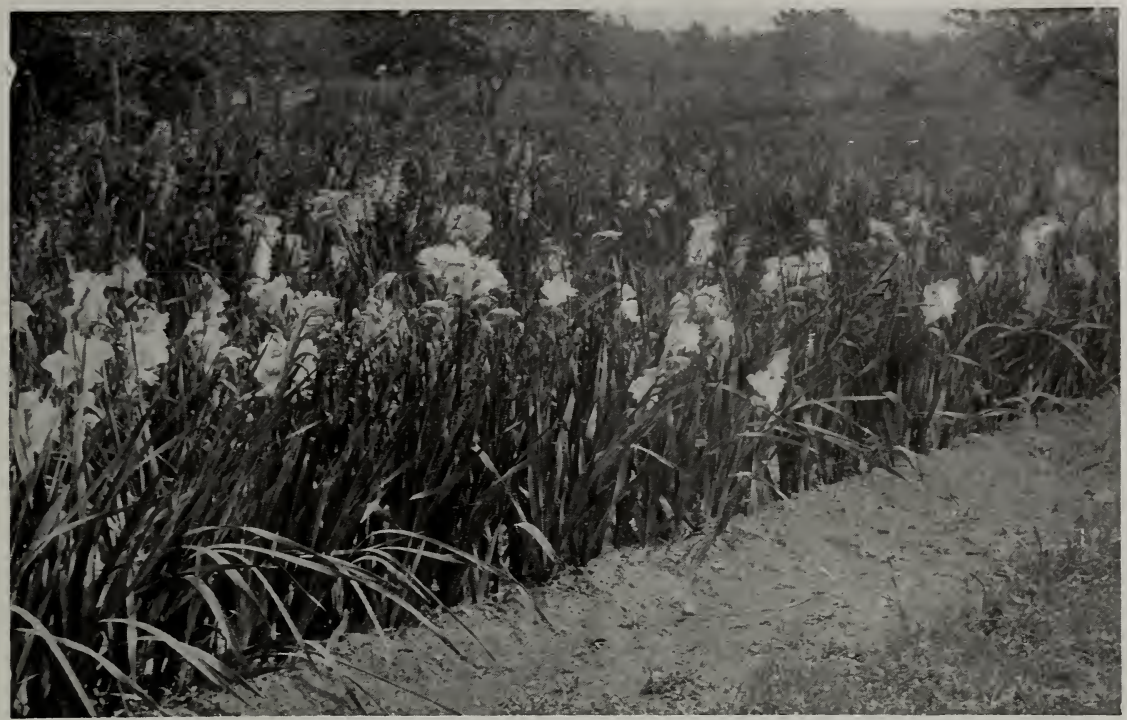

Partial View of one of my Gladiolus Fields. "America" in Foreground.

\section{Gladioli}

The new Gladioli are without an equal either for bedding or borders. As a cut flower they are far superior to any other summer bloomer, either for lasting qualities or for the various uses for which they can be employed. If planted by the last of May they will bloom by the first to the middle of August, if cared for properly.

The Way to Plant-Dig the row or bed from 8 to 10 inches deep, then spread a liberal amount of good fertilizer in the bottom of the row or bed, then rake it in thoroughly before planting your bulbs; but if stable dressing is used it should be spaded in when the bed is first dug over. I find that hen dressing can be used, giving first-class results, if applied properly; but it must be put in the bottom of the drill or bed, then covered with fully an inch of soil before the bulbs are planted. The bulbs after being planted should then be covered from 1 to 6 inches deep. Just as soon as they show their heads through the ground, they should be cultivated. If this is continued once a week till they commence to flower, one will be sure of first-class results.

\section{Special Offers}

Knowing many of my customer are not familiar with the different named varieties, but want good, large flowering varieties, regardless of the name, and wishing to guarantee satisfaction and give them the greatest value possible for their money, I make these Special Offers, all of which I recommend. The varieties I am to use in these offers are only the largest and best.

RECOMMENDED SPECIAL OFFER: For Massing and Borders. 100 Gladioli; 25 America; 25 Augusta, 25 Independence and 25 . Ietropolitan. The 100 prepaid for $\$ 5.00$. 100 each of the four varieties for $\$ 15.00$, prepaid. These are four of the finest.

RECOMMENDED OFFER. One dozen named varieties, 12 different colors, varieties that are large, and that I will guarantee to give satisfaction, prepaid to any part of North America, for $\$ 1.00$. I make this offer to insure you good results, and in the selection will give you the benefit of my experience.

TRIAL COLLECTION. Five giant-flowering Gladioli, five different colors, for 25 cents, prepaid.

\section{New and Choice Gladioli for 1920}

This remarkable collection of 11 Phenomenal Gladioli prepaid for $\$ 4.00$. This collection includes the very largest and best of all Gladioli.

CLARA HUNT. Alexander's New Gladioli Seedling. Named expressly for Mrs. W. W. Hunt of South Weymouth, Mass., in recognition of her great love for Gladioli. This new creation is one of the largest and finest of my seedlings. A deep geranium pink, with faint cream color markings on the three lower petals. Highly recommended. $\$ 1.00$ each.

ETHEL WARDWELL. Rich deep scarlet-red; throat streaked and dotted white. 25 vents each.

ISA TINKHAM. A very rich deep purple-crimson; a very popular shade. Flowers of medium size and produced on long spikes. 25 cents each.
FASCINATION. An exceptionally delicate blending of pale yellow and pale Persian lilac; the three lower petals conspicuously blotehed rich deep carmine. 35 cents each.

LILY WHITE. A new White Gladioli that attracted considerable attention this past season. A reliable first-class early blossoming variety. One of the finest and clearest white rarieties; if not the purest white. 50 cents each.

MARY ELIZABETH. In exquisite shade between pale laelia pink and Persian lilac; the three lower petals blotched deep spinel red. 25 cents each. 


\section{GLADIOLI-Continued.}

MRS. JOHN HAYS HAMMOND. Alexander's New Gladioli Seedling. Named expressly for and with permission of Mrs. John Hays Hammond of Prides Crossing, Mass., in recognition of her great admiration of beautiful flowers. A beautiful begonia rose, blending to and streaked with a glowing velvety carmine-red; throat Baryta yellow thickly dotted and splashed a dull carmine-red. Gigantic flowers produced upon good sturdy plants. One of the largest and finest Gladioli to my knowlledge. Highly recommended. $\$ 1.00$ each.

MISS FLORA SPRAGUE. White overlaid salmonpink; throat deep carmine-red. 25 cents each.

PEGGY SAVAGE. Alexander's New Gladioli Seedling. Flaming deep scarlet, with conspicuous throat markings of napthalene-yellow. Very large and attractive. Highly recommended. \$1.00 each.
MRYTLE. O ne of the finest and most delicate new Gladioli. It is early flowering; in perfect alignment on straight spikes, the opening buds very closely resemble creamy-pink tinted rosebuds with slightly flaring petals. Clearest dainty rose-pink, softly dissolving into a throat of clear creamy-white, its cool angelic beauty is most entrancing. Distinctive in form and color; and of good size. It has been described as a fine Mayflower pink, almost exactly the color of the trailing arbutus. 20 cents each; $\$ 2.00$ per dozen.

PILGRIM. Rose-red blending to a darker shade at tips, with mahogany-red blotch in throat. Medium sized spikes producing more than the average number of well-expanded flowers. 25 cents each.

\section{Standard Gladioli.}

I will ship this collection of 52 varieties prepaid for $\$ 5.00$.

A Gladiolus bed displaying one color is most effective the Gladioli are ideal for massing, and add greatly to the surroundings.

AMERICA. (Banning.) Universally acknowledged "King of Gladioli." Gigantic flowers of clear lavender-pink. 10 cents each; 75 cents per dozen; $\$ 5.00$ per 100 .

AEROPLANE. The color is a beautiful clear, deep pink with an exquisite pure white throat. Individual flowers are very large and massive, being well arranged, and many open at a time. 35 cents each; $\$ 3.50$ per dozen.

ANNIE WIGMAN. Pale yellow, with a small dark blotch in the throat. Very attractive. 10 cents each; $\$ 1.00$ per dozen.

AUGUSTA. (Hallock.) Lovely pure white with blue anthers. 10 cents each; 75 cents per dozen; $\$ 5.00$ per 100 .

BARON J. HULOT. (Lemoine). The finest blue to date. A rich deep color of indigo blue. 10 cents each; $\$ 1.00$ per dozen.

BRENCHLE YENSIS. (Youell.) Vermilion-scarlet. Fine variety. 10 cents each; 75 cents per dozen.

CHICAGO WHITE. The Early Snow-white. Extra early and a fine pure white. 10 cents each; $\$ 1.00$ per dozen.

COLUMBIA. Bright scarlet, freely blotched and penciled with blush-purple. Throat mottled. 10 cents each: $\$ 1.00$ per dozen.

CRACKER JACK. (Cowee.) Large flowers of velvety dark red, throats spotted with yellow and dark maroon; a most sensational variety. 10 cents each; $\$ 1.00$ per dozen.

DAWN. (Tracy.) A most beautiful coral-pink A long, graceful spike of magnificently formed flowers opens up at almost the same time. The color and texture of this variety make it indispensable for cutting. 25 cents each; $\$ 2.50$ per doz.

EMPRESS OF INDIA. (Velthuys.) Gigantic New Dark Gladiolus. The very finest and nearest to black of any Gladiolus. A valuable novelty and a variety. worthy of my highest recommendation; of gigantic size and beautiful rich, dark mahoganyred color. 10 cents each; $\$ 1.00$ per dozen; $\$ 8.00$ per 100 .

EUROPA. (Pfitzer.) Sterling Large White Gladiolus. This European variety has attracted great attention, and is considered by many experts to be the best pure white to date, having the finest spikes, the best individual flowers, and being the purest in its snowy whiteness. 20 cents each; $\$ 2.00$ per dozen.

FAUST. A large, velvety, carmine-red. A very rich color and a long spike. 10 cents each; $\$ 1.00$ per dozen.
Geo. F. Elcock. Exquisite New Gladioli Seedling. A spectacular variety, producing large, well-exlaid salmon-pink; throat bright crimson-maron. 25 cents each.

GIANT PINK. Large flower, dark pink shade with brilliant throat markings of dark red; tall, strong grower; flowers well arranged. 15 cents each; $\$ 1.50$ per dozen.

GLORY OF HOLLAND. White with slight tinting of pale pink, and anthers of delicate lavender. 10 cents each; $\$ 1.00$ per dozen.

GLOWING GEM. Alexander's New Gladiolus. The plants are of strikingly vigorous, healthy growth, producing well expanded blossoms perfectly arranged upon tall, sturdy spikes. Color a beautiful, glowing scarlet. The most prominent feature of this variety is its color, which attracts great attention. 50 cents each; $\$ 5.00$ per dozen.

HALLEY. (De Ruyter.) Delightful salmon-rose with beautiful creamy blotch. Very large. 10 cents each; 75 cents per dozen.

HOLLINDIA. A charming shade of salmon, tinted yellow. 10 cents each; $\$ 1.00$ per dozen.

IDA. (Groff). The flower spike is large; the flowers are pure white, daintily overlaid and veined a delicate pinkish lavender; the stamens are purple and the stigmas pale carmine. A remarkable variety of excellent habit. 20 cents each; $\$ 2.00$ per dozen.

INDEPENDENCE. (Woodruff.) Ruch clear, deep pink, with throat markings of dark red. A very tall and strong grower, of great substance. One of the best for cutting. 5 cts. each; 50 cents per dozen.

JESSIE. Fine velvety red, with a long spike of flowers. 5 cents each; 50 cents per dozen.

KЕОKUK. Deep, brilliant pink, clouded and spotted slate-blue. Very odd. 15 cents each; $\$ 1.50$ per dozen.

KING HUMBERT. The magnificent flowers are a very showy, brilliant scarlet with a pure white stripe through the center of each petal. 35 cents each; $\$ 3.50$ per dozen.

KLONDYKE. (Christy.) Strong, vigorous plant, blooming early; flowers round, well opened, of clear primrose-yellow, with blotches of vivid crimson-maroon on the three lower petals. 10 cents each; $\$ 1.00$ per dozen.

KUNDERDI "GLORY." The famous Ruftled Gladiolus. (Originated by A. E. Kunderd.) Each lower petal is exquisitely ruffed and fluted. Massive, beautiful flowers which are well expanded; color, delicate cream-pink with an effective crimson stripe through the center of each lower petal. 10 cents each; $\$ 1.00$ per doz. 


\section{GLADIOLI-Continued.}

LIBERTY. (Tracy.) A bright red with strikingly marked primrose throat. Large, well expanded flowers. 10 cents each; $\$ 1.00$ per dozen.

LILY LEHMAN. (Alkemade.) N e w Holland Gladiolus. An imported variety of great promise. Delicate cream, very slightly tinted pink. A delightful white; very waxy and lily-like. Flowers of large size and slightly ruffed on the edges. The blossoms are not set close on the spike like the "American-type," but grow on longer stems like lilies. The effect of a vase of them is very beautiful, with a graceful airiness, very different from the with a graceful airiness, sorts. 10 cents each; $\$ 1.00$ per dozen; $\$ 8.00$ per 100 .

MAY. (Crawford.) A lovely, pure white flower, finely flaked with rose-earmine. 10 cents each; $\$ 1.00$ per dozen.

MEADOWVALE. (Cowee.) One of the purest of whites, without a shade of color except in the throat, where there is a touch of vivid crimson; the three lower petals have slight center markings of clear crimson pink. 10 cents each; $\$ 1.00$ per dozen.

METROPOLITAN. (Gr.) The gem of this collection. The flowers are of the largest size, being rell expanded. The color combination is most fascinating; the flowers are of light crimson-scarlet with a beautiul deep cherry throat, edged salmonpink, the whole being delightfully striped rich crimson. 5 cents each; 50 cents per dozen.

MRS. E. M. SMITH. Alexander's New Gladiolus Seedling. A very attractive new variety of great substance. Deep pink with bright cherry throat; two lower petals edged primrose-rellow. Plant vigourous; spike straight and strong. 5 cents each; 50 cents per dozen.

MRS. FRANGIS KING. (Coblentz.) A pleasing shade of light scarlet. Flowers are large and rell arranged on a strong spike, there being four to six open at one time. One of the best in existence. 10 cents each; 75 cents per dozen; $\$ 5.00$ per 100 .

MRS. FRANK PENDLETON, JR. (Kunderd.) Awarded First-class Certificate of Merit by the Massachusetts Horticultural Society, Boston. This new variety is the result of crossing the best of the largest flowered types, and is now a type of its own. The color is the most exquisite salmonpink, with a very conspicuous blood-red blotch in the throat on the lower petals. 15 cents each; $\$ 1.50$ per doz.

MRS. WATT. In coloring, one of the most distinct varieties grown; a glowing, winecrimson. One of the choicest newer varieties and a novelty that no garden should be without. 25 cents each; $\$ 2.50$ per dozen.

MRS. W. E. FRYER. Poppy-red with amber-white throat, and a blotch of crimson. A unique and pleasing shade, excellent for cut-flowers and charming for the garden. 25 cents each; $\$ 2.50$ per dozen.

NAZINSCOTT. (Childs.) Bright blood-scarlet with deep, velvety crimson-black blotches and white mottlings in throats. 15 cents each; $\$ 1.50$ per dozen.

NOVELTY. (Groff.) An exceedingly odd variety of beautiful light salmon color with orange-yellow throat, the whole being dotted and mottled with erimson. 5 cents each; 50 cents per dozen.
NIAGARA. (Banning.) A wonderful new Gladiolus of sterling quality. In color the flowers are a delightful cream shade, with the two lower petals daintily marked canary-yellow. The throat is attractively splashed with rich carmine. The stamens are purple, and the stigmas pale carmine. 15 cents each; $\$ 1.50$ per dozen.

PANAMA. (Banning), A wonderful new Seedling from "America," which it resembles, but is a deeper pink. Flowers very large and spike long. 15 cents each; $\$ 1.50$ per dozen; $\$ 10.00$ per 100

PEACOCK. Beautiful light blue, with erimson and bright yellow throat, marked like a giant pans. 10 cents each; $\$ 1.00$ per dozen.

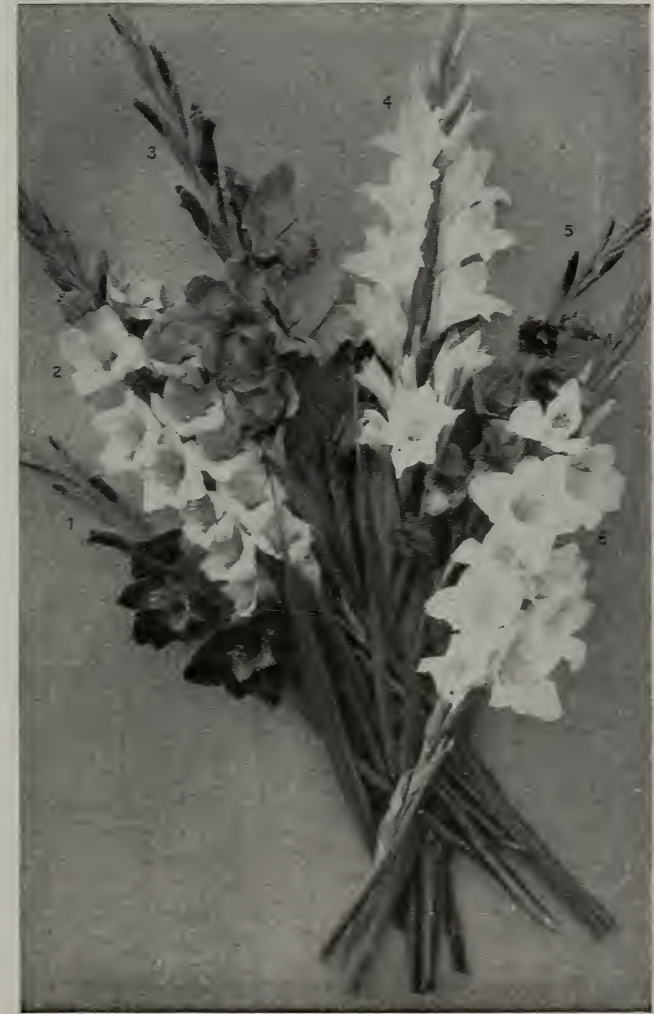

THE MARVELOUS SIX FOR 40 CENTS, PREPAID 


\section{GLADIOLI-Continued.}

PEACE. (Groff.) Wonderful white Gladiolus. Gigantic flowers are borne on a magnificent tall spike; the entire plant shows a vigorous, healthy constitution. The wide open flowers are of a glistening white, with an attractive narrow stripe of purplish carmine through the center of each lower petal. This extra throat marking is not a detriment to its beauty but adds to its attractiveness. The noblest white Gladiolus. 15 cents each; $\$ 1.50$ per dozen.

PINK AUGUSTA. Deep pink, same form as Augusta. 10 cents each; $\$ 1.00$ per dozen.

PRESIDENT TAFT. (Stewart.) An exquisite variety of delicate salmon-pink, shaded darker at edge with deep crimson blotch in throat and an attractive white line through each petal. A grand variety which evokes words of praise wherever exhibited. The spikes and flowers are of largest size. 25 cents each; $\$ 2.50$ per dozen.

PRINCEPS. (Dr. Van Fleet.) The Amaryllisflowered Gladiolus. Color, rich crimson with intense shadings in the throat and broad white blotches across the lower petals. 10 cents each; $\$ 1.00$ per dozen.

PRIMULINUS HYBRIDS. These hybrids, produced by crossing the species Prymulinus with the Candavensis type, are extremely dainty and graceful in form. The upper petal droops, forming a "hood." The colors range from primrose yellow to a beautiful rose. 15 cents each; $\$ 1.50$ per dozen.

ROUGE TORCH. Large, creamy-white flowers, with a rouge torch-like tongue on the lower petals, making a very striking contrast. 20 cents each; $\$ 2.00$ per dozen.

SCARSDALE. (Cowee.) A grand Galdioius with large lavender-colored flowers, shaded beautiful dark rose; extra large spikes growing very erect. 15 cents each; $\$ 1.50$ per dozen.
SCHWABEN (Pfitzer.) Beautiful New Yellow GLADIOLUS. Finest of German importations. This striking new Gladiolus is a pure canary-yellow, shading to soft sulphur-yellow when opening: the deep golden-yellow center is blotched with brilliant brownish-carmine. Foliage is large and vigorous, of a beautiful dark green, which, combined with the brilliant sulphur-colored flowers makes it very effective for groups and beds. The brownish-carmine blotch being very deeply set in the throat does not reduce the entire effect, and hardly makes any appearance unless flower is examined. 25 cents each; $\$ 2.50$ per dozen.

STERLING, MINNESOTA, Or LAFA YETTE. (Groff.) A beautiful pale yellow with rich cherry throat. One of our finest of this season's seedlings and nearest in color to the New Ruffled Gladiolus, "Kunderdi Glory." A perfect beauty. 10 cents each; $\$ 1.00$ per dozen; $\$ 8.00$ per 100 .

SULPHUR QUEEN, A remarkably clear sulphuryellow. 10 cents each; $\$ 1.00$ per dozen.

THE KING. (Groff.) A beautiful, rich, deep purple with an ideal chrome yellow throat, the lower petals veined white. The flowers are from 4 to 6 inches in diameter, borne on long spikes. Very large and showy. 10 cents each; $\$ 1.00$ per dozen.

WAR. (Groff.) A Giant Red Gladiolus. Largest of all Gladioli, showing from 4 to 6 open flowers at one time. Deep blood red, shading to crimson. 25 cents each; $\$ 2.50$ per dozen.

WM. FALCONER. A long spike and flowers of large size. Beautiful, clear light pink. 15 cents each; $\$ 1.50 \mathrm{pr}$ doz.

WOODROW. A very exquisite and attractive variety. Scarlet flower with deep yellow throat. 5 cents each; 50 cents per dozen.

\section{My Special Gladiolus Mixtures}

Some of the very best strains ever offered; also some of the best and grandest named varieties introduced in this country.

\section{Alexander's Special Select Mixture}

This strain comprises a large range of some of the very best colors and varieties ever offered at these prices, consisting principally of the best white, yellow and pink shades.

First size: 75 cents per dozen, prepaid, or $\$ 5.00$ per 100 , prepaid.

\section{Alexander's Select Mixture}

This strain comprises a large range of colors, flowering red and dark shades.

First size: 75 cents per dozen, prepaid, or $\$ 5.00$ per 100 , prepaid; $\$ 35.00$ per 1,000 , prepaid.

\section{My Special Mixture of Groff's}

This strain comprises a large range of colors, some of the best Groffs grown, consisting of many red, crimson and darker shades.

First size: 50 cents per dozen, prepaid; $\$ 4.00$ per 100 , prepaid or $\$ 35.00$ per 1,000 , prepaid.

\section{My Grand Mixture}

This strain comprises a large range of colors; some of the older types, together with a large number of new varieties, making it perfectly satisfactory and by far the best obtainable for the prices.

First size: 50 cents per dozen, prepaid; $\$ 3.00$ per 100 , prepaid; $\$ 25.00$ per 1,000 , prepaid.

\section{Gift Boxes}

For the purpose of stimulating a greater interest in the Galdiolus, and believing many would be glad to send a few bulbs to a friend, we select and pack in neat boxes 15 bulbs of choice varieties, consisting of - of a fine select mixture of rare colors, all for $\$ 1.00$, prepaid.

Also boxes containing one dozen good assorted Gladiolus for 60 cents, prepaid. These are all good flowering bulbs.

Your card can be enclosed if desired.

\section{Mr. J. K. Alexander,-}

The Dahlia King.

Dear Sirs, -

I have received my order for the 10 Dahlia Bulbs and I thank you for the extra one you sent. Everything was perfect, from the labels on each variety; they were carefully packed, in a neat little box.

\section{Respectfully,}

Miss Elizabeth McConnell.

Dahlias arrived in good condition and am very much pleased with the selection you made for me. Will write you later, letting you know what success I have growing them. 


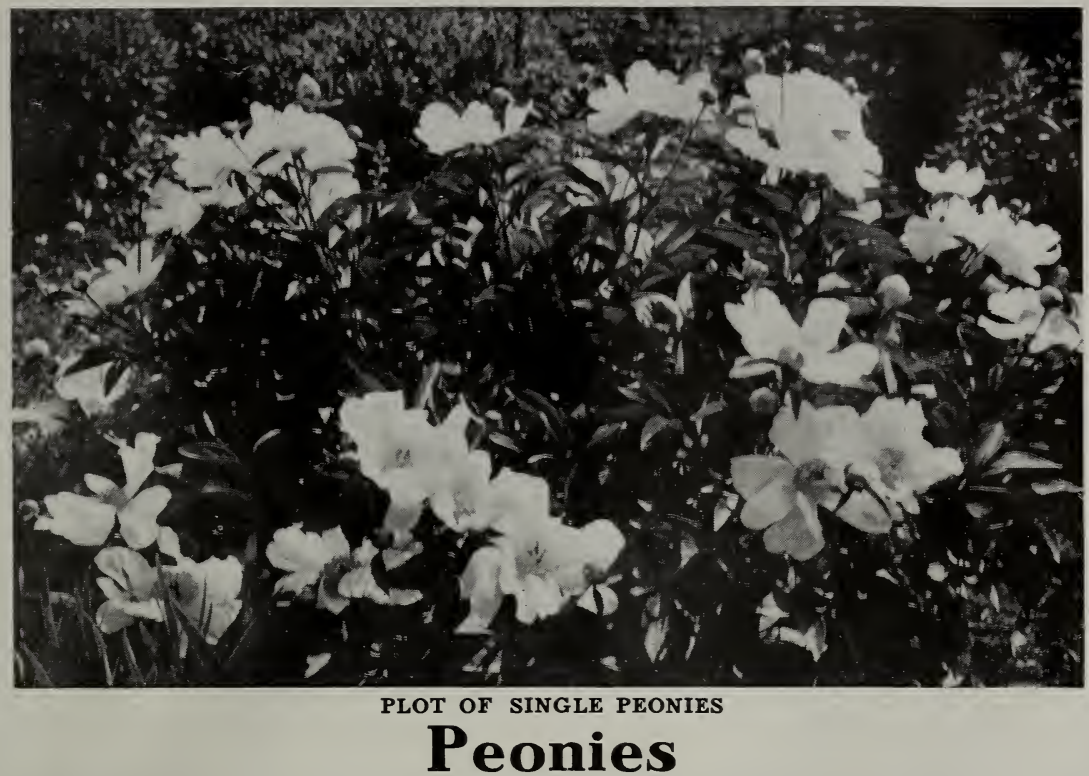

The Peonies are among the noblest and most magnificent of our herbaceous plants. They are the "Queen of Spring Flowers," and are well adapted for massing in beds, and particularly valuable for planting in groups throughout the perennial or shrubbery border, where their brilliant hues add beauty to the entire surroundings. Their requirements are so simple - a good, rich, deep soil; they are perfectly hardy, and produce their wealth of flowers in great abundance. Roots can be shipped from early April until the end of May; and from August until freezing time, in the fall. Purchaser to pay shipping charges.

ADMIRAL DEWEY. (Hollis, 1903). Rose-pink, shaded heliotrope; large, high-built flower. $\$ 3.00$ each.

ALEXANDER DUMAS. (Guerin, 1862.) Medium sized, light violet-rose crown; has creamy white collar of narrow petals, mingled with wide center petals; fragrant. Mledium height, free-bloomer. early mid-season. Good cut-flower variety. $\$ 1.00$ each.

AVALANCHE. (Crousse, 1886.) Large, compact crown. Milk-white, cream-white collar, center tinted lilac-white; prominent carmine flecks lengthwise of the petals. Frangrant. $\$ 2.00$ each.

BRIDE. (Terry.) Fragrant; light pink fading to white. 50 cents each.

BARON JAMES DE ROTHSCHILD. (Guerin, 1850.) Medium size crown; guards and very wide crown petals, pale lilac-rose; narrow, creamwhite collar petals. Fragrant; vigorous; medium height; free-flowering; mid-season. \$1.00 each.

CHARLOTTE CUSHMAN. (Hollis, 1904.) A deep pink. Very large and very double. \$3.00 each.

CLAIRE DUBOIS. (Crousse, 1886.) Very large, globular, rose type. Uniform color-clear deep violet-rose, tipped silvery white. Erect tall, strong grower. Late bloomer. $\$ \mathbf{2 . 0 0}$ each.

DORCHESTER. (Richardson Seedling.) Salmonpink. A late but very beautiful variety. $\$ \mathbf{\$ 1 . 5 0}$ each.

DR. BRETTONEAU. (Guerin, 1850.) Large, compact, rose type. Guards are pale lilac, center milkwhite, shaded amber. Fragrant. $\$ 1.00$ each.

DUC D'WELLINGTON. (Calot, 1859.) Large, bomb type. Very fragrant. White guards and sulphur-yellow center. One of the finest white varieties. Medium tall, tigorous grower; free flowering. Late bloomer. \$1.00 each.
EDULIS SUPERBA. (Lemon, 1824.) Large, loose, flat crown. Bright mauve-pink; collar mixed with lilac. Very fragrant. Early bloomer. Strong, upright; very free-flowering. One of the very best commercial pinks for Decoration Day. 50 cents each; $\$ 5.00$ per dozen.

FELIX CROUSSE. Large, globular, typical bomb type. Brilliant red. A strong vigorous grower; medium height and free bloomer. \$1.00 each.

FESTIVA MAXIMA. (Meillez, 1851.) Very large, globular type. Pure white center, prominently flecked crimson; outer petals sometimes, faint lilacwhite on first opening. Very tall, strong, vigorous grower. Early bloomer. The most popular white variety for cut-flowers. $\$ 1.00$ each.

FLASHLIGHT. (Hollis, 1906.) A very large Japanese variety, globular. Guards light Tyrian rose; narrow center; petals amber-yellow, shading to pink at base. Medium height, erect, strong grower. Early bloomer. One of the best of this type. $\$ \mathbf{\$ 1 0 . 0 0}$ each.

GEORGE WASHINGTON. A very large, deep red, semi-rose type; one of the earlest varieties to bloom. Fragrant. \$2.00 each.

GLORY. (Hollis, 1907.) Medium size; flat, loose, light Tyrian rose. Guards narrow, ligulated; center petals golden-yellow, tipped silver. Tall and erect. $\$ 3.00$ each.

HUMEI. (Anderson, 1810.) Large, compact, globular, rose type. Cherry pink with silver tips. Cinnamon fragrance. Weak stem. Very late bloomer. 50 cents each.

INNOCENCE. (Hollis.) Japanese Medium size, flat. Guards are lilac-rose and narrow. Center petals canary-yellow. Fragrant. $\$ 5.00$ each. 


\section{PEONIES-Continued.}

LA ESPERANCE. (Calot, 1845.) A lovely rosepink; fine form; full center and very fragrant. Vigorous and profuse bloomer. \$2.00 each.

LA SUBLIME. (Parmenter.) This is a fine flower of deep crimson. Very striking on account of its rich color. A reliable variety. $\$ 1.00$ each.

MADAM DUCEL. (Mechin, 1880.) Large, globular, typical bomb. Light mauve-rose with silver reflex. Fragrant. Strong grower, medium height, very free flowering. Extra good. \$1.00 each.

MADAME CHAUMY. (Calot, 1864.) Medium size, very compact, globular, perfect rose type, Pale rose-lilac with silvery reflex; central petals slightly darker, flecked crimson. Medium height; free-flowering. Mid-season bloomer. $\$ 1.00$ each.

MADAME CROUSSE. (Calot, 1866.) Medium size, globular, crown type. Pure white, center delicately flecked with crimson on crown. Strong, medium height; free-flowering. Mid-season bloomer. One of the most handsome of the white varieties. $\$ 1.00$ each.

MADAME DE VERNEVILLE. (Crousse, 1885.) Large, very full, bomb type. Pure white; center blush-white when first open, fading to pure white; prominent carmine flecks. Fragrant. Medium height, extra free-flowering. Early bloomer. Extra good. \$1.00 each.

MADAME FOREL. (Crousse, 1881.) Large, very compact, rose type. Violet-rose with a silvery tipped center. Fragrant. Medium height. Late bloomer. $\$ 1.00$ each.

MADAME EMILE GALLE. (Crousse, 1881.) Large double, cup-shaped, imbricated flowers; a delicate sea-shell pink with touches of heliotrope and lavender. Scarce and rare. $\$ 2.00$ each.
MARIE LEMOINE. (Calot, 1864.) Large, very compact, globular crown. Guards light violetrose, collar milk-white, crown lilac-white. Very fragrant. Strong, erect, tall, free-flowering. Midseason bloomer. Extra fine. \$1.00 each.

MONSIEUR BARRAL. (Calot, 1866.) Very large, compact, flat rose type. Uniform pale lilac-rose. Very fragrant. Erect, tall, strong grower; freeflowering. Late bloomer. 75 cents each.

MONSIEUR JULES ELIE. (Crousse, 1888.) Very large, compact, high crown. Pale lilac-rose, colla lighter, shaded amber-yellow at the base. Very fragrant. Medium height, strong grower. Extra fine. \$1.00 each.

NE PLUS ULTRA. (Meillez, 1856.) Medium size, flat, loose, semi-double. Uniform pure mauve, tipped silver. Fragrant. Medium height. Early mid-season bloomer. $\$ 1.00$ each.

PLUTACH. A glorious orb of radiant glistening crimson. $\$ 1.00$ each.

QUEEN VICTORIA. (Kelway.) Large, globular in form, medium loose, low crown. Milk-white guards, tinted flesh; center cream-white with crimson spots. Very fragrant. Medium height. Strong free-flowering. Mid-season bloomer. One of the best. $\$ 1.00$ each.

RED CROSS. (Hollis, 1904.) A brilliant crimson. Medium size, full double; very late bloomer. $\$ 5.00$ each.

SIR THOMAS J. LIPTON. (Kelway.) Free-flowering; large flower with golden stamens in the center of rosy petals. $\$ 1.00$ each.

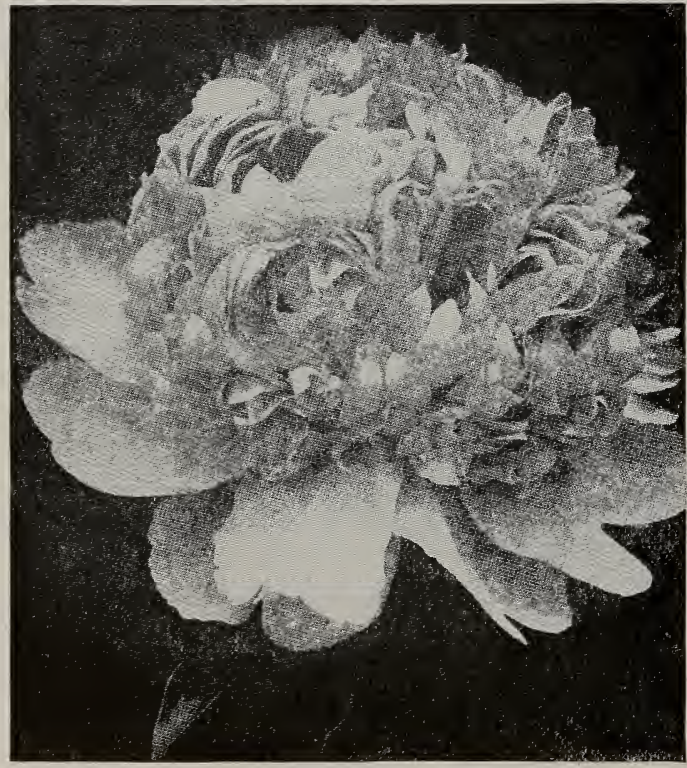

Alexander Dumas
UMBELLATA ROSEA. (Unknown.) Large, informal rose type. Guards violetrose, shading to amber-white center. Very strong, upright grower; free-flowering. One of the earliest varieties. Extra fine for both landscape and cut-flower purposes. 75 cents each.

VILLE DE NANCY. (Calot, 1872.) Large, medium compact. Carmine-rose with silvery reflex. Tall, very strong, stiff stems; free-flowering. Late bloomer. Extra good. \$1.00 each.

VENUS. (Kelway.) Very large, high, compact crown. Pale Hydrangea-pink, collar lighter. Tall. Free-bloomer. Extra good. \$3.00 each.

WELCOME GUEST. (Hollis.) Silverypink, shading white. A very fine, delicate flower. $\$ 5.00$ each.

\section{Paeonia Officinalis}

This type is the real old-fashioned "Peony," and commences to bloom from ten days to two weeks ahead of the other varieties. All are strong growers, with large, full, double flowers. 50 cents each; $\$ 5.00$ per dozen, prepaid.

Pink and White. Guard petals clear pink center waxy white. Very fragrant.

ROSEA. Beautiful clear rose-pink. One of the finest.

RUBRA. Brilliant, glowing purple-crimson.

We recommend THE FLOWER GROWER to our friends and customers. Published monthly. All flower lovers should be regular subscribers. Subscription price three years, $\$ 2.00$, one year, $\$ 1.00$.

Madison Cooper, Publisher, Calcium, N. Y. 


\section{Single Peonies}

Single Peonies are becoming more and more popular each year, many people considering them more artistic and beautiful than the double ones. They are exceptionally attractive, and not at all common in the garden, making them especially desirable. They are very airy and stand out prominently, producing their blossoms in great abundance. The great variety of colors, and their fantastic shapes make them ideal for the home garden. For Landscape effects, they are especially valuable, on account of their brilliant colors, and upright habit, and the fact they are not easily beaten down by storms.

I have a very choice collection, principally seedlings, possessing the most delicate and rarest shades; but my stock is insufficient for me to offer them under names, therefore, I offer them under color, and at greatly reduced prices. I have over two hundred different shades in Single Peonies, and can furnish in the following colors:
Large deep rose-pink
75 cents each
Large-flowered pale pink
75 cents each.
Largest deep crimson shades $\mathbf{7 5}$ cents each.
Pale pink and delicate shades $\mathbf{5 0}$ cents each.
White shades, and pure white $\$ 1.00$ each

$\begin{array}{ll}\text { Deep pink shades } & 50 \text { cents each. } \\ \text { Crimson shades } & 50 \text { cents each. } \\ \text { Pink and white shades } & 50 \text { cents each. }\end{array}$

Purple-crimson shades

50 cents each.

\section{Mixed Peonies}

Each season, in handling our Peonies, a small amount becomes mixed in handling them, many times the very choicest varieties. It does not prove worth while for me to plant these separately, to ascertain their names, so I am offering them at 50 cents each, as long as they last. This mixture is apt to include some of the best new things, not offered in my catalog; and includes both Double and Single varieties.

Mr. J. K. Alexander.

Freedom Sta., Ohio,

Dear Sir,-

I am returning by the same mail the Dahlia tuber "Darlene" which I bought of you this Spring. I have had it four weeks in a hot bed, watering only as needed, and it shows no signs of starting, and is rotting at the end, which was evidently cut off in digging. While the other five I had from you, including "Mina Burgle,", "Baron G. deGrancy," "J. M. Goodrich," "Frank A. Walker"; and "Minos," gratis, are just growing fine. I don't want to be unreasonable, but in accordance with your offer in your catalog, would be very much pleased if you cared to send me a tuber of

"Darlene" or something else that would grow. I changed the label as it fell out where it had rotted away at the end. I was much pleased with the quality of your Dahlias and wish to thank you for "Minos," which you sent gratis.

Very truly yours,

Mrs. F. A. Lorenz.

My dear Sir,-

Your shipment of Gladioli bulbs reached me all right and I am thanking you for extra bulbs. I am anticipating much pleasure from them, as I already have enjoyed your Dablias.

Yours truly,

Alice C. Brigham.

Broadway at 61 st Street,

$$
\text { New York, N.I., }
$$

$6 / 13 / 19$.

J. K. Alexander,

East Bridgewater, Mass.

Dear Sir -

This is to acknowledge receipt of the Dahlia bulb "Stradella" that you sent to me gratis with my last order.

I certainly appreciate your kindness, as the gift was so unexpected, and should I have success in bringing the flower to perfection, will take pleasure in telling my friends.

Again, thanking you I am,

Sincerely yours,

J. H. Slason.

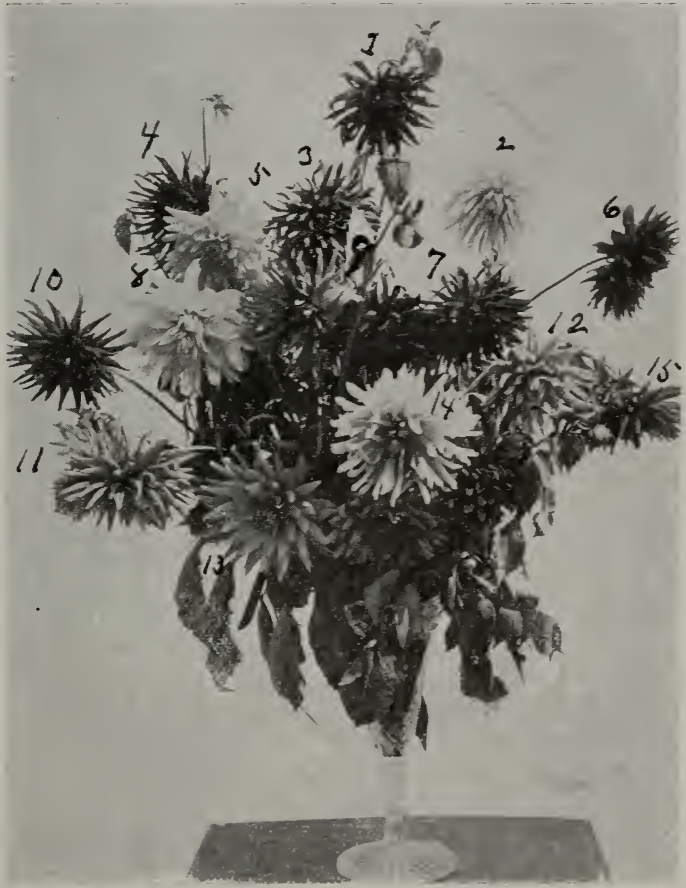

THIS LIST OF SUPERB CACTUS DAHLIAS For $\$ 4.00$, prepaid.
1 Sirius
2 Marjorie Castleton
3 Gen. Butler
4 Mrs. Henry Wirth
5 Mme. Henri Cayeux
6 Thos. Challis
7 Reliable
8 Henri Cayeux

9 Indomitable 


\section{Liberty Iris, or Fleur de Lis}

Familiar and well-beloved flowers of spring. The purity of their beauty and their haunting fragrance are decidedly refreshing. The winsome, modest beauty of some, forming a striking contrast to their more glorious sisters arrayed in a sheen of iridescent splendor. They fairly outrival the Orchid in the wide range of coloring, which includes yellows, from light canary to deep golden; blues from soft lavender to intense purples; reds, from pinkish mauve to claret and maroon; beautiful bronzes, and pure whites; and some varieties are marked and margined with other colors in exquisite harmony.

The Iris succeeds in partial shade, but gives the most satisfactory results in a dry, sunny location. They are perfectly hardy and require only ordinary cultivation; growing luxuriantly. They should be planted early in the spring: March, April and May; or in the fall during August, September and October. Plant the bud or crown about two inches below the surface.

In this description, Standards signify the three standards (erect, or upright curling petals); Fallsthe three falls, or drooping petals.

My collection of Liberty Iris consists of the very newest and choicest up-to-date novelties and the finest standard varieties.

\section{New Irises for 1920}

My New Irises are the largest and finest of the Irises to date, possessing the newest and rarest colors. Their flowers are nearly twice the size of the common yellow Fleur de Lis.

This superb collection of Six Wonderful New Irises, prepaid to any part of the United States or Canada for $\$ 3.00$.

LOHENGRIN. Standards and Falls of cattleyarose; one of the largest and best of the Irises to my knowledge, and without exception the finest pink shade. 75 cents each.

LORD GREY. Clouded rose-fawn. A very odd and novel shade, very rare and uncommon among the Irises. 50 cents each.

NIBELUNGEN. Standards of fawn-yellow; Falls of violet-purple with fawn margins. A very handsome variety, that I can highly recommend. One of the very largest. $\$ 1.00$ each.

PENELOPE. White delicately veined reddish-violet. 25 cents each.

RHEIN NIXE. The largest of its color to my knowledge, and in my estimation one of the very best. Standards, pure white; Falls, deep violet blue, with a white edge. 75 cents each.

WALHALLA. Standards, lavender; Falls, wine-crimson. Large finely formed flowers. 50 cents each.

\section{General Collection of Iris}

I will send this collection of 17 Irises for $\$ 4.00$, prepaid.

BROOKLYN, Syn. CHA L CEDONIA OY JOHAN d'WORTH. A very reliable standard variety of medium height. Standards light mauve; Falls, purple, heavily veined. A prolific bloomer. 20 cents each; $\$ 2.00$ per dozen.

ELIZABETH. Standards, pale lavender, darker in center; Falls, mauve, melting into pale blue. A very large, attractive flower. 25 cents each; $\$ 2.50$ per dozen.

FLAVESCENS. $\mathrm{s} \mathrm{t}$ a $\mathrm{nd}$ a $\mathrm{rds}$ and Falls, a delicate shade of soft yellow. Very fragrant; fine for massing. 20 cents each; $\$ 2.00$ per dozen.

FLORENTINA ALBA, Syn. SILVER KING. The finest white variety. Standards and Falls, porcelain, changing to pure white. Large and very fragrant. 20 cents each; $\$ 2.00$ per dozen.
HERANT. Standards, beautiful lavender-blue; Falls blue. Very large and tall. 25 cents each; $\$ 2.50$ per dozen.

HER MAJESTY. (New). Very attractive on account of its rich and unusual color. Standards, heliotrope of tissue-like delicacy; inner petals straw and lavender; Falls, light mauve, traced with white. A very fine, rich flower. 35 cents each; $\$ 3.50$ per dozen.

HONORABILIS. The most popular of all Iris Similar to Sans Souci. Standards, beautiful golden yellow; Falls, rich mahogany-brown. Very effective. 15 cents each; $\$ 1.50$ per dozen.

JACEQUESIANA, SYn. CAROLINE de SANSEL, and CONSCIENCE. Standards, bright, coppery crimson; Falls, rich maroon. 75 cents each.

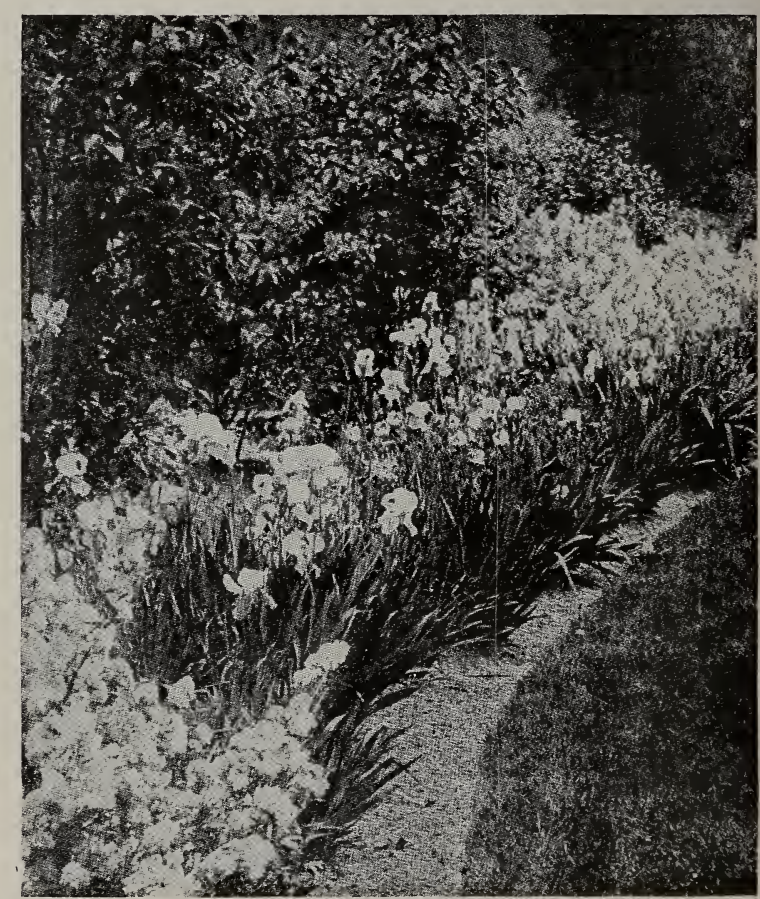

Iris in Border. 


\section{Alexander's Large Flowering Cannas}

The Cannas are the most popular of all Bedding Plants; standing our pre-eminently, because they give such good results and can be grown satisfactorily in all parts of the country. They do well in all sections, succeeding in any sunny position, and in any kind of soil, but responding quickly to liberal treatment and good care. For the very best results, the bed should be thoroughly and deeply spaded, and a generous amount of well-decayed manure or any commerical fertilizer, thoroughly incorporated. Watering the plants frequently throughout the season, leads them to grow more rapidly, and produce a much more luxuriant foliage, and larger and more beautiful flowers. When you water them, do it thoroughly. For best effects plant in masses, using one or two colors; setting the plants between eighteen inches and two feet apart each way, and from four to six inches deep.

If you wish to plant a bed 7 feet in diameter, it will require 20 roots or plants; a bed 10 feet in diameter will require 40 roots; a bed 13 feet in diameter requires 65 roots. In planting a circular bed, always plant the taller variety in the center, with the more dwarf around the outside.

SPECIAL CANNA OFFER. For beds from 5 to 7 feet in diameter; I will send 15 Cannas, my selection, 5 tall of one variety for the center and 10 shorter of another variety for the outside. In making this selection, I will use my best judgment as to blending of colors, and endeavor to give you those I believe will give you best satisfaction. Prepaid to any part of the United States or Canada for \$3.00.

\section{Four New and Rare Cannas for 1920.}

This Collection of Four Giant-Flowering Cannas, the choicest and most wonderful of the New Cannas to my knowledge, I will ship prepaid, to any part of the United States or Canada_for $\$ \mathbf{\$ 1 . 5 0}$.

GITY OF PORTLAND. This new creation received the certificate of merit from the Society of American Florists, which alone speaks for its superior qualities. It is recommended as the finest of the pink varieties. It is a very good blossoming variety, growing between four and five feet in height, and producing flowers of the most beautiful deep glowing pink. The foliage is a rich shade of green. 50 cents each; $\$ 5.00$ per dozen.

THE PRESIDENT. This new variety is the leading red Canna of the day, being without exception the best red in commerce. The immense trusses of flowers are borne well above the foliage on upright stems. It grows about four feet in height, and is a mass of color, making it very desirable for the most exclusive gardens. I can highly recommend this variety, and to all who wish the best red Canna for their bed, I believe they will be well satisfied with "The President." This variety is one of Wintzer's greatest accomplishments. 50 cents each; $\$ 5.00$ per dozen.

WINTZER'S COLOSSAL. The largest and brightest of the Orchid-flowering Cannas: individual florets often measuring over eight inches across. In color, a vivid scarlet, on of the most brilliant and showy, and a Canna that it is a pleasure to recommend. The plants are strong, vigorous growers, averaging between four and six feet in height, and producing their gigantic flowers on immense trusses, making it very desirable for the center of a bed. The foliage is a rich, deep green, and is produced very luxuriantly. 35 cents each; $\$ 3.50$ per dozen.

\section{YELLOW KING HUMBERT or OU E N} HELENE. Identical with "King Humbert" in habit of growth and flowering, and producing showy flowers of yellow attractively dotted with red. It has proven so satisfactory that there is a possibility that the demand will equal that of "King Humbert" in a few years. The plants grow between four and five feet in height, having green foliage. 35 cents each; $\$ 3.50$ per dozen.

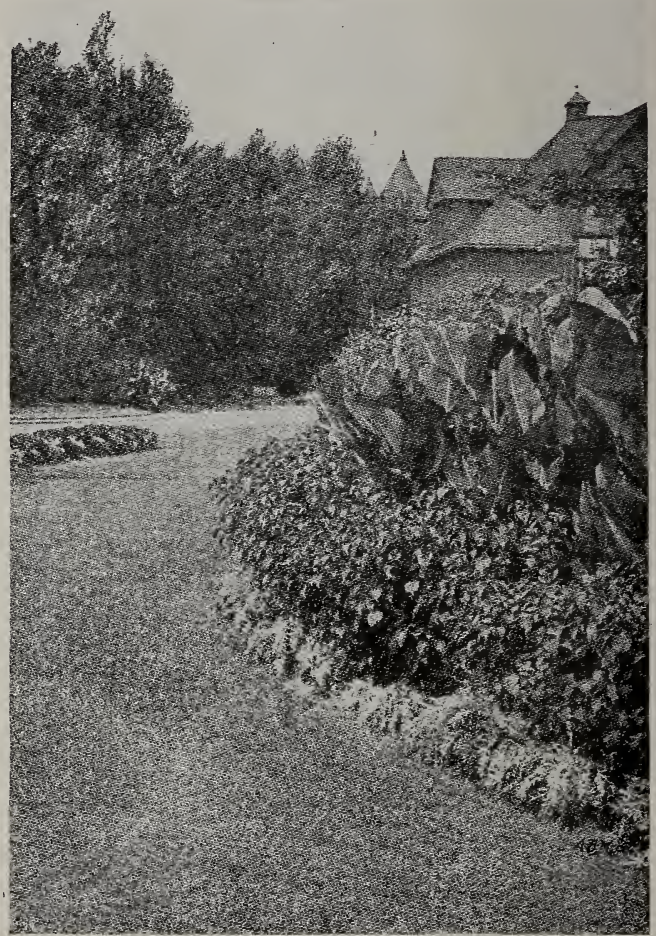

Cannas in Border.

\section{Six Peerless Cannas}

Of the many Cannas in existence, the following are the best and most popular, having the largest flowers, the most beautiful colors, and giving the most showy effects in beds. I will ship prepaid, to any part of the United States or Canada, one of each of these Six Choice Cannas for $\mathbf{\$ 1 . 5 0}$.

BEACON. The plants grow between four and five feet in height, usually about four feet; and are strong and sturdy. The foliage is deep green, and very luxuriant. Great masses of rich cardinal flowers, borne well above the foliage. A very free bloomer, and one of the best of the dwarf reds. 25 cents each: $\$ 2.50$ per dozen.
DRAGON. Among the very dark reds, "Dragon" cannot be excelled for depth of color and abundance of bloom. A deep ox-blood-red, a rich beautiful color. The plants are about three feet in height, and produce their flowers in good-sized clusters. 25 cents each; $\$ 2.50$ per`dozen. 
CANNAS-Continued.

JANE ADDAMS. A bright buttercup-yellow, with

MORNING GLOW. An exquisite pink, blending to rich red. The flowers are produced in large trusses and harmonize perfectly with the beautiful bronze foliage. This variety grows about four feet in height and is a continual bloomer. 25 cents each; $\$ 2.50$ per dozen.

plants grow between four and five feet in height Foliage green. 25 cents each; $\$ 2.50$ per dozen.

KING HUMBERT. The pride of the Orchid-flowering Canna; flowers large, of a bright orange-scarlet effectively streaked with crimson. The plants grow about four feet in height and produce a very luxuriant foliage, which is thick and leathery and of a rich bronze with brownish green stripes. 25 cents each; $\$ 2.50$ per dozen.

NEW YORK. The plants are strong and robust, growing between four and five feet in height. I think one of the finest for the center of a bed. In color, scarlet with plum colored foliage. 25 cents each; \$2.50 per dozen.

SPECIAL CANNA OFFER. My entire collection of TEN CHOICE CANNAS, shipped, prepaid, to any part ofthe United States or Canada for \$2.25.

\section{Sauromatum Simlense}

(Black Calla.)

A rare and curious garden bulb, with odd flowers and luxuriant palm-like foliage. The spathe of this Calla-shaped flower is between one and two feet in length, with tapering point, and is of very large size. Color of bloom; green on the outside, inside yellow, spotted with purple; which makes it very curious. The foliage is very large; the leaf-stem being light green thickly dotted a deep green, making it very attractive and novel. The blossoms appear shortly after the bulbs are planted; followed by the luxuriant leaves that remain a curiosity the entire season. This is sometimes called "The Snake Lily" and is very rare. These plants create a genuine sensation.

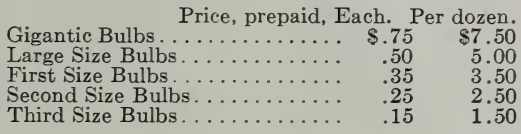

\section{Caladium Esculentum}

\section{(Elephant's Ear)}

One of the most effective plants in cultivation for beds, borders, or for planting out upon the lawn; they are used extensively in many of the public parks, where their decorative value is greatly appreciated. To obtain the best results, it should be planted where it will obtain plenty of water and an abundance of rich compost. Frequent cultivation around the growing plant insures the best results. When full size it stands from 6 to 10 feet in height, and bears immense light green leaves, 3 to 4 feet long by $1 \frac{1}{2}$ to $2 \frac{1}{2}$ feet wide. The size of the plant depends upon the size of the bulb, and its care.

Price prepaid, Each Per dozen Gigantic Bulbs.............. \$.75 $\$ 7.50$

Large Size Bulbs......... $\quad .50 \quad 5.00$

First Size Bulbs........... $\quad .35 \quad 3.50$

Second Size Bulbs.......... $\quad .25 \quad 2.50$

Third Size Bulbs......... . $\quad .15 \quad 1.50$

\section{Zephyranthes Zephyr Flower, or Fairy Lily.}

Beautiful dwarf, bulbous plant, very effective for masses or borders, flowering with great profusion during the summer. They are also suitable for pot culture. Six bulbs clustered in a 6-inch pot in the autumn will give a fine display during the winter8 inches high.

Z E P H Y R A N T H E S . Crimson-scarlet, beautiful Amaryllis-like flowers, very effective. 20 cents each; \$2.00 per dozen, prepaid.

Island Heights Yacht Club, Island Heights, New Jersey,

My dear Mr. Alexander,June 12th, 1919.

Received bulbs you so kindly replaced, and thank you for same.

Am enclosing postage for the Parcel Post.

Very truly,

Mrs. P. W. Adler.

28 Berkeley St., Somerville, Mass.,

28 June 12, 1919.

Mr. J. K. Alexander,-

Mr. J. K. Ale

Please accept my thanks for the prompt manner in which you adjusted the loss of my order for Dahlia bulbs, that was lost in the Parcel Post.

I received the duplicate order that you so kindly sent on June 2nd and was greatly pleased with the fine collection sent. I am returning your letter to the Somerville Post Office and their letter, so you will have it for future reference. Your first order has not shown up as yet, but if it does, I assure you I will hand it to some of my friends that will use it as an ad for your Dahlia Farm, and also your square and upright dealing with your customer. Please excuse my negligence for not answering sooner. Again I wish to thank you, and beg to remain,

Very truly yours,

Mr. J. K. Alexander,

East Bridgewater, Mass.

Sours, Irwin.

Dear Sir -

Malden, Mass., June 7, 1919.

The Dahlia bulbs arrived and are doing fine. I should have ordered a larger variety, but am expecting to move shortly. Hope another season to be able to have another nice garden. Thanks for extra one. Shall prize it highly.

Sincerely,

Mrs. A. B. Leighton.

$11 \mathrm{~A}$ Orchard St., Beachmont, Mass.,

June 10, 1919.

My dear Mr. Alexander,-

I am rather late in acknowledging the box of bulbs you sent me. I am pleased to get a "Geisha" this season, and wish to thank you for the "Vivian" you sent gratis.

All the bulbs you sent are up and growing well. My small garden was called the bright spot on the street last year. Your Dahlias were admired by everyone passing by. 


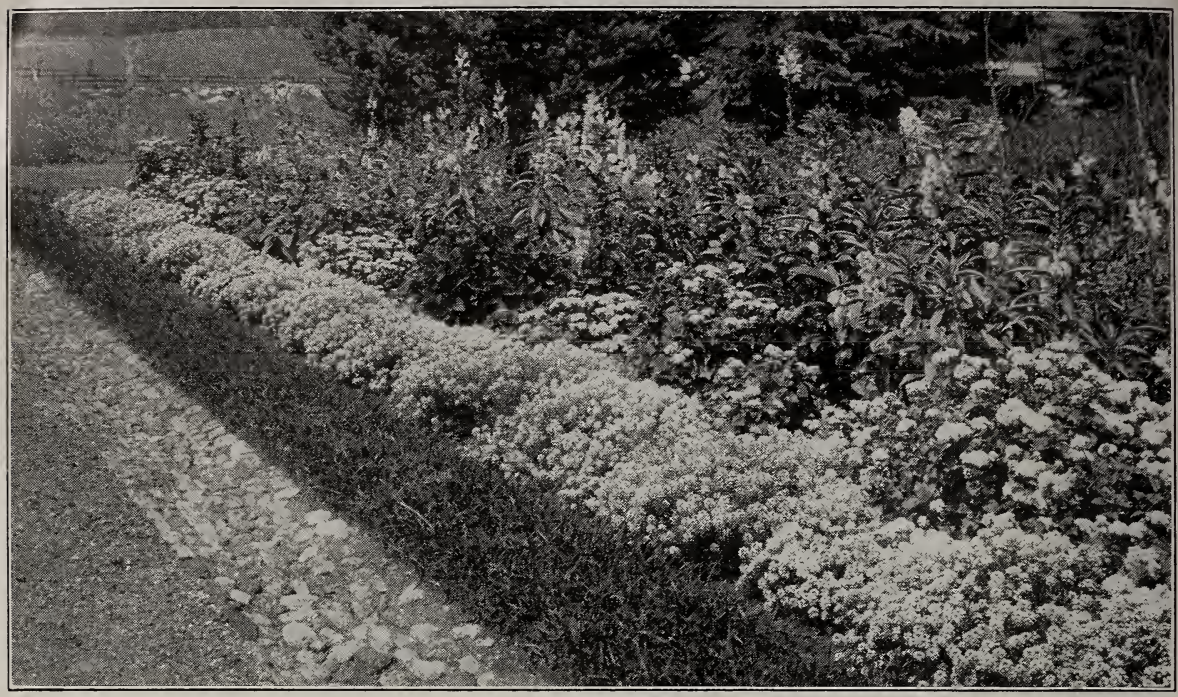

\section{Hardy Perennials}

We are sure that nothing gives our customers greater satisfaction about their grounds than a well arranged flower garden of Hardy Plants. With a proper selection of varieties, flowers may be had in bloom from early spring until severe frost, and many of them will succeed where less hardy varieties would prove a total failure once planted they make a permanent bed and are therefore less trouble and expense than where tender plants are used, and while they are of the easiest culture and do better with less care than most other varieties, yet they well repay any extra attention that may be given them. A properly prepared bed to receive them should be deeply forked or spaded with a liberal supply of well rotted manure thoroughly worked in. Bone-dust and also some commercial fertilizers produce excellent results and may be applied in small quantities several times during the season and lightly raked into the soil.

Although not absolutely necessary, a winter covering of long, strong, coarse litter or similar material will afford such protection as to guard against sudden changes of freezing and thawing, and the plants will be in a stronger condition to make an early start in the spring to pay for the little trouble incurred. Manure can also be used, but a heavy covering on evergreen varieties would be likely to rot and kill them.

\section{ACHILLEA-"The Pearl"}

A summer-blooming variety, worthy of a place in every garden. The flowers are pure white, very double, and are produced in large sprays on long stems; are much used by florists for cut-flower work. Perfectly hardy. Particularly desirable for cemetery planting. 18 inches. 25 cents each; $\$ 2.00$ per dozen, prepaid.

\section{AQUILEGIAS or COLUMBINES}

The Columbines are one of the most elegant and beautiful of hardy plants, producing their graceful spurred flowers on stems rising two or more feet above a beautifully divided foliage. They should be planted wherever their presence will serve tolighten up a too stiff and formal planting. No other plant has so airy a grace as the Columbine, is more generous of its blooms, or is more effectively adapted for cut flowers. They are not at all particular as to soil or location, although they prefer a sandy loam and a moist but well drained, sunny position. Their period of flowering covers the late spring and early summer months, and they usually make themselves at home in any hardy border or rockery.

Choice Hybrids, including all the well-known colors.

25 cents each; $\$ 2.50$ per dozen.

\section{HARDY ASTERS}

Michaelmas Daisies or Starworts

These are among the showiest of our late-flowering hardy plants, giving a wealth of bloom during September and October; a season when most other hardy flowers are past. For best effects, they should be planted in masses of one color.
ASTER, ALPINIS. Indispensable for the rockery, or edge of hardy borders; grows 6 to 10 inches high and bears large showy bluish-purple flower in May June and July. 25 cents each.

ASTER, AMELLUS BESSARABISCUS. Rich, purplish-blue flowers, with orange centers. Good for cutting. 12 to 18 inches in height; blossoming in August and September. 25 cents each.

ASTER, ESMA. Very similar to "Amellus Bessarabicus" in habit and color. 25 cents each.

\section{ASTILBE or SPIRAEA}

ASTILBE. 15 to 24 inches. Flowers white, buds tinted rose-pink. Finely cut foliage. 35 cents each

\section{BOLT ONIA}

ASTEROIDES (False Chamomile). This is an excellent decorative flower. The bushy plants grow 5 feet high, covered with small, white flowers of the Aster-type. Very effective for vases. Strong plants 20 cents each; $\$ 2.00$ per dozen, prepaid.

\section{CENTAUREA (Corn Flower)}

CENTAUREA, MONTANA (Perennial Cornflower). Plants from 12 to 15 inches in height; a rosy purple flowering from July to September. 25 cents each; $\$ 2.50$ per dozen.

\section{CHR YSANTHEMUM}

CHR YSANTHEMUM. Old-fashioned large-flowering hardy Chrysanthemums. A very beautiful absolutely hardy plant, popular in all old-fashioned gardens. In color, a very deep rose-pink. 2 to 3 feet high. 25 cents each; $\$ 2.50$ per dozen. 


\section{HARDY PERENNIALS-Continued.}

\section{DELPHINIUM OP HARDY LARKSPUR}

Mrs. Ely, author of "A Woman's Hardy Garden," says:

"Perennial Larkspur may be planted as soon as the spring has opened. The ground should be well drained and carefully prepared, but manure must not be allowed to come in contact with the roots, or grubs are apt to destroy the plants. A little finely ground bone meal dug around each plant early in May will be of benefit, and in late autumn coal ashes should be shifted over the crowns of the plants to protect them from the white grub, which is their only enemy. The stalks being very tender, the plants should be staked when they are about three eet high, to protect them from heavy winds. Larkspur begins to bloom about June 20 th, and by cutting off the plants close to the ground, as soon as each crop of flowers has faded, a second and third crop of flowers will succeed. Each time the plants are cut a little bone meal should be dug about them."

BELLADONNA. The freest and most continuous bloomer of all, never being out of flower from the end of June until cut down by hard frost. The clear turquoise-blue of its flowers is not equaled for delicacy and beauty by any other flower. 35 cents each; $\$ 3.50$ per dozen; $\$ 15.00$ per 100 .

Choice Hybrids, including all the standard colors. I can supply these in mixtures only. 25 cents each; $\$ 2.50$ per dozen.

\section{FUNKIA Plantain Lily}

FUNKIA-Plantain Lily. The Plantain Lilies are among the easiest plants to manage; their broad, massive foliage makes them attractive subjects for the border, even when not in flower. They succeed equally well in sun or shade. 20 cents each; $\$ 2.00$ per dozen.

\section{HEMEROCALLIS \\ (Yellow Day Lily.)}

Popular hardy plants, belonging to the Lily family. They succeed everywhere and should always be included in the border of old-fashioned hardy plants.

AURANTIACA. A beautiful, large trumpet-shaped Day Lily with fragrant orange flowers. One of the most satisfactory; height 2 to 3 feet; flowers in June and July. 25 cents each; $\$ 2.50$ per dozen, prepaid.

FLAVA. (Yellow Day Lily.) The best known variety; very fragrant, deep, clear lemon-yellow; flowers in June; height, 2 to 3 feet. 25 cents each; $\$ 2.00$ per dozen.

FULVA (Tawny Day Lily). One of the best known varieties. Height, 4 to 5 fet; trumpet-shaped flowers of a bronzy orange-red color; flowers from June to August. 15 cents each; $\$ 1.50$ per dozen, prepaid.

\section{HARDY GARDEN HELIOTROPE} Valeriana (Spurred Flower.

VALERIANA OFFICINALIS. The old-fashioned garden Heliotrope with pinkish or lavender flowers with Heliotrope fragrance; flowers in June and July; Height, 4 feet. 25 cents each; $\$ 2.50$ per dozen, prepaid.

\section{LYSIMACHIA}

CLETHROIDES (Loose-strife). A fine hardy plant, between one and two feet in height that blossoms during July, August and September. Long dense recurved spikes of pure white flowers. 25 cents each.

\section{MONARDA (Bergamot}

\section{Bee Balm.}

DID YMA ROSRA (Bee Balm). Showy plants growing from 2 to 3 feet in height, that succeed in any soil, or position. Bright colored flowers of a reddish rose shade, with aromatic foliage. Blossoms during July and August. 25 cents each; $\$ 2.50$ per dozen.

\section{PAPAVER or POPPY}

PAPAVER NUDICAULE (Iceland Poppy). 8 to 12 inches in height. These produce showy graceful flowers all summer. A good mixture of the most beautiful shades of orange, yellow and white. Good for massing in borders, or in the rock garden. 25 cents each.

\section{DIANTHUS-PINKS}

DIANTHUS BARBATUS (Sweet William). 10 to 20 inches high, blossoming in July and August. One of the oldest garden flowers, which perpetuates itself by self-sowing. Colors, a good mixture of the most beautiful shades of crimson, white and Newport pink. 25 cents each.

DIANTHUS PLUMARIUS (Scotch Pink). A favorite plant in old time gardens, blossoming in June, and having a distinct fragrance. Flowers are double, and of a beautiful clear light pink. 9 inches in height. 25 cents each; $\$ 2.00$ per dozen.

DIANTHUS PLUMARIUS DELICATA. New seedling pink, from Dianthus plumarius. Very beautiful delicate pale pink flowers, blossoming in June. 9 inches in height. 35 cents each.

DIANTHUS PLUMARIUS ALBA. Pure white double flowers of the same species. 25 cents each.

DIANTHUS, SEMPERFLORENA. 9 to 12 inches. Semi-double flowers; Newport pink, with crimsonred center. 35 cents each.

\section{PHYSOSTEGIA}

PHYSOSTEGIA VIRGINIANA (Ladies' Pink). An elegant plant with dark, glossy, green foliage and long spikes of soft rose flowers; excellent for cutting. Height, 2 to 3 feet. 20 cents each; $\$ 2.00$ per dozen, prepaid.

\section{RUDBECKI A \\ (Cone Flower.)}

Indispensable plants for the hardy border; grow and thrive anywhere, giving a wealth of bloom, which are well suited for cutting.

GOLDEN GLOW. A well-known popular plant strong, robust grower, attaining a height of 5 to six feet; produces masses of double golden yellow flowers from July to September. 15 cents each.

\section{TRADESCANTI A}

(Spider Lily.)

TRADESCANTIA VIRGINICA.

An all-round plant for wet or dry, sunny or shady situations. continuing in bloom from early summer until frost. Clear blue, three-petaled flowers in clusters on long stems, and long, pointed foliage. Height 2 feet. 15 cents each; $\$ 1.50$ per dozen. prepaid.

VAR. ALBA. White flowers. A pretty contrast when planted with the purple variety. 20 cents each, $\$ 2.00$ per dozen, prepaid.

\section{VIOLA-VIOLETS}

VIOLA CORNUTA. A very beautiful hardy violet, blossoming from April until frost, and growing from 6 to 8 inches in height. Large pale blue flowers. A fine border plant. 20 cents each.

\section{YUCCA}

\section{(Adam's Needle.)}

YUCCA FILAMENTOSA. A stately foliage and flowering plant equally imposing in solitary or group planting; always conspicuous. The broad, sword-like foliage is evergreen, while in mid-summer it shows great erect, branching stems, bearing a showy display of pendant, creamy white bells. Very fragrant: flowers in July and August. 25 cents each; $\$ 2.50$ per dozen; large plants, 50 cents each, prepaid. 


\section{Hardy Perennial Phlox}

Among hardy harbaceous plants, none are more gorgeous, and more easily grown than the Phlox. They are perfectly hardy, and will grow in any soil, and produce magnificent spikes of the most gorgeous flowers, lasting weeks, and year after year, with but little care. These plants will produce an abundance of flowers, which are very fragrant.

\section{Choice New Phlox for 1920}

TEN CHOICE NEW PHLOX FOR 1920, prepaid to any part of the United States or Canada for $\$ 4.00$.

CREPUSCULE. A superb variety with very large individual flowers, which form a truss of immense size. The coloring of this variety is very odd, and attracts considerable comment; a very difficult variety to describe; an odd shade of lavender violet, shading to pale blue. 35 cents each.

EUROPA. A very distinct new Phlox that wins instant favor, and proves deserving of a place in the gardens of the most particular. The plants are remarkably sturdy, and of good erect habit. The individual flowers and trusses are very large, which add to its value. White with a decided crimsoncarmine eye. 50 cents each.

FRAU ANTON BUCHNER. An exquisite pure white variety. Plants are of medium height, and very sturdy. The individual flowers of this variety are much larger than those of any other white variety to my knowledge. 50 cents each.

GENERAL VAN HEUTSZ. A very brilliant salmonred, with an occasional light shading at the center. A variety of medium height, and good habit. This is one of the showiest. 35 cents each.

HENRY MURGER. An exceptionally good salmon variety having good perfect trusses, and very large individual flowers. This is one of the very finest salmon-rose shades, and has all the good qualities of a Phlox. It is one of the very largest varieties I have seen. 35 cents each.

RIVERTON JEWELL. A lovely shade of mauverose, illuminated by a brilliant carmine-red eye. 50 cents each.
RYNSTROM. One of the largest and finest of the new Phloxes. Equally as good, if not better than the popular "Pantheon" and of very nearly the same color; possibly there is a trifle more pink in it. A beautiful salmon-rose. It is also described as a carmine rose, similar to the popular Rose "Paul Neyron." 35 cents each.

THOR. A most beautiful and lively shade of deep salmon-pink, suffused and overlaid with a scarlet glow; with a light, almost white halo surrounding the aniline-red eye. This lovely variety holds a supreme place among the deep salmon-pink, and it is a pleasure to recommend this new creation. It is of exceptionally good habit, being tall and sturdy, and producing immense trusses. Flowers are of gigantic size. 50 cents each.

VIKING. A splendid new variety, that has proven one of the latest to blossom. A pleasing soft salmon-rose. 50 cents each.

W. C. EGAN. One of the very finest Phloxes yet introduced, and a variety that wins instant favor, while the individual flowers, according to color chart, are of a delicate lilac, illuminated by a large bright solferino eye, the color effect, as a whole, is a pleasing shade of soft pink. In habit of growth it is very strong and vigorous; producing immense panicles of flowers nine inches high by seven across, and the individual flowers are frequently over $1 \frac{1}{3}$ inches in diameter. Very satisfactory, and one that I can highly recommend. 50 cents each.

\section{Select Standard Phlox}

Price 20 cents each; $\$ 2.00$ per dozen; $\$ 12.00$ per 100 , except where noted, prepaid. If wanted in large lots send for 1,000 rates.

ALCESTE. A sensational variety, possessing an entirely new and rare color-deep violet, shading almost to blue. The plant is of strong, sturdy growth of medium height, and produces remarkably large trusses; individual flower of largest size. 25 cents each; $\$ 2.50$ per dozen.

BRIDESMAID. One of the very best Phlox grown. White with large rose-crimson center. Very showy and desirable. Plants exceptionally sturdy, producing large trusses. Medium height. 20 cents each; $\$ 2.00$ per dozen.

DELIVERANCE. A very tall, pleasing variety. Deep pink with crimson eye. Individual flowers are large; very fragrant.

ECLAIREUR. An old favorite. One of the largest and best. Bright rose-carmine with light halo, a bright and cheerful face. The plants are very strong and sturdy, making a perfect border. 20 cents each; $\$ 2.00$ per doz.

ELIZABETH CAMPBELL. New Pink Phlox. Very bright salmon-pink with lighter pink shadings and dark red eye. Attracted more attention in our fields than any other variety; one of the handsomest. The best pink Phlox to date. 50 cents each; $\$ 5.00$ per dozen.

INDEPENDENCE. Pure white; medium height.

JEANNE D'ARC or SNOW-QUEEN. Undoubtedly the very finest pure white variety to date. The plants are extra strong growers of medium height, producing exceptionally large heads. Ideal for hedging or massing.
LA VOGUE. Silvery rose with deeper rose eye. 25 cents each.

LE MAHDI. Up-to-date Novelty Phlox. A perfect beauty of special merit. The entirely new and rare color of this variety makes it one of the most desirable. The flower is a rich, dark violetpurple, a color rare among Phlox. The plants are very strong and robust; they are of medium height and produce large flower trusses; individual flowers exceptionally large. 25 cents each; $\$ 2.50$ per dozen.

MARY LOUISE. This is one of the most attractive varieties we are offering. Pure white with distinct violet-rose eye. 20 cents each.

MISS LINGARD. New Glossy Foliage Phlox. White, with faint lilac eye. This variety is an early-flowering Phlox and blooms continually throughout the season. Plants are tall, sturdy, and first-class for bedding. Dark, glossy, green foliage. 25 cents each.

PANTHEON. Flowers are very large; pink or salmon-rose; one of the most distinct varieties. Sturdy plants of medium height. 25 cents each.

PROFESSOR SCHLIEMAN. Bright lilac-rose with carmine eye.

R. P. STRUTHERS. Very strong grower with large heads of fiery salmon-red. Very showy. Fine for borders or hedging. 25 cents each. The above collection of 14 distinct named varieties for $\$ 3.00$, prepaid. 


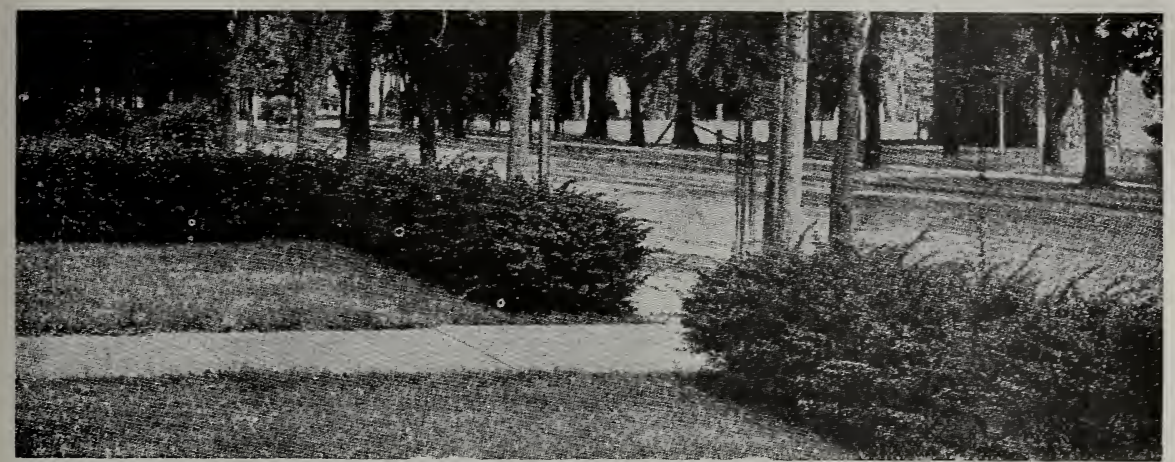

\section{Hedge of Berberis Thunbergii}

\section{Hedge Plants-Shipped by Express, Collect}

The hedge is a valuable adjunct in embellishing the home grounds. It lends an air of individuality and refinement. Below we list the most popular varieties in present use.

\section{BERBERIS THUNBERGII}

\section{(Japan Barberry.)}

Where a low, dwarf, deciduous hedge is wanted, nothing equals this beautiful Barberry. It is of spreading habit, growing extremely thick right from the base and requires but little pruning to keep it in shape. The leaves are small, light green, and towards fall assume rich, brilliant colors, the fruit or berries becoming scarlet; absolutely hardy in all parts of the country.

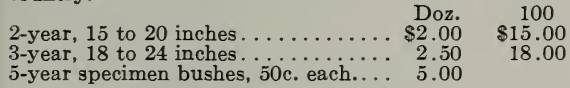

LIGUSTRUM. Privet

\section{LIGUSTRUM, Amurence}

\section{(A moor River Privet).}

An ornamental hedge plant somewhat similar to the famous California Privet, but hardier. A tallgrowing upright shrub; leaves dark green and lustrous, tardily deciduous; nearly evergreen in the South. Flowers white, in erect panicles. Splendid for hedges.

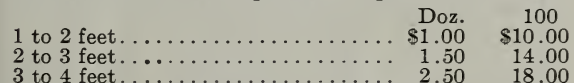

L. IBOTA (Japanese Privet). L. One of the hardiest and most graceful of all Privets; branches spreading and curving; foliage grayish green; produces white, fragrant flowers in June, followed by black berries; valuable for specimen, mass planting or hedges. 2 to 3 feet, 20 cents; $\$ 12.00$ per 100 . 3 to 4 feet, 25 cents; $\$ 15.00$ per 100 .

\section{CALIFORNIA PRIVET}

\section{OVALIFOLIUM (California Privet).}

Of all ornamental hedge plants this is the most popular and more of it is planted than all others combined. Its foliage is a rich, dark green and is nearly evergreen, remaining on the plant until mid-winter. It is of free growth and succeeds under the most adverse conditions, such as under dense shade of trees where other plants would not exist.

To form a dense hedge from the base up the plants should be severely pruned the first two seasons. Plant the one-year old size 8 inches apart in the row, the larger sizes 10 to 12 inches apart. Strong, bushy, 2-year, 24 to 30 inches... $1.75 \quad 12.00$

\section{Ornamental and Flowering Shrubs}

\section{Shipped by Express at Purchaser's Expense}

It is my aim to produce everything in flowering shrubbery that is useful, hardy and worthy of cultivation in our climate. A good shrub collection will present the greatest variety of color throughout the season, both in flower and foliage. Even in winter it is attractive in appearance from the gracefulness of its stem and branches, and from the color of its bark. When right selections are made it will serve almost as well as evergreens to shut out from view fences or other low unsightly objects.

\section{AMYGDALUS, Almond} ALMOND FLORE ROSEO PLENO (Double Pink Almond). Flowers double, rose-colored. 18 to 24 inches, 75 cents each. 24 to 30 inches, $\$ 1.00$ each

\section{BERBERIS. Barberry}

\section{BERBERIS THUNBERGII}

Where a low, dwarf, deciduous hedge is wanted nothing equals this beautiful Barberry. It is of spreading habit, growing extremely thick right from the base and requires but little pruning to keep it in shape. The leaves are small, light green, and towards fall assume rich, brilliant colors, the fruit or berries becoming scarlet; absolutely hardy in all parts of the country.

\begin{tabular}{|c|c|}
\hline $\begin{array}{l}10 \text { to } 15 \text { inches. } \\
15 \text { to } 20 \text { inches. } \\
18 \text { to } 24 \text { inches. } \\
5 \text {-year specimen }\end{array}$ & $\begin{array}{r}\text { Doz. } \\
. \$ 1.50 \\
2.00 \\
2.50 \\
5.00\end{array}$ \\
\hline
\end{tabular}

BERBERIS ATROPURPUREA (Purple-leaved Barberry). Especially remarkable for its dense. upright growth and its brilliant purple foliage and fruit. When full grown, plants attain a height of 4 to 5 feet, but can be kept at any height below this by shearing. It is very valuable as a border for walks and drives. Splendid for a hedge; also good as single specimens on the lawn. Endures partial shade and is perfectly hardy.

18 to 24 inches.

.$\$ 0.50 \quad \$ 5.00$ 


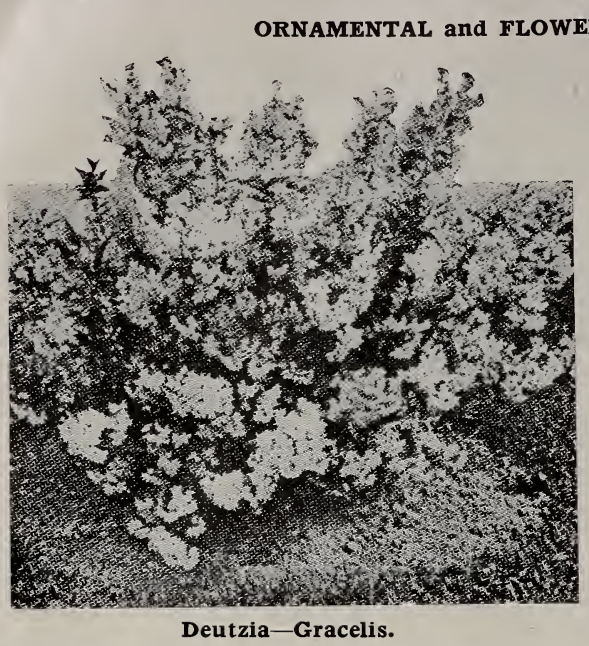

Caragana. Siberian Pea

CARAGANA ARBORESCENS. Very hardy, tallgrowing shrub, producing small yellow flowers in June; dark green wood and neat foliage.

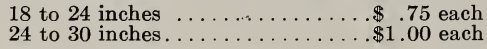

\section{CORNUS. Cornel or Dogwood}

C.-FLAVIRAMEA (Golden-bark Dogwood). S. Branches yellow, and makes a striking contrast when planted with variety rubra; the red-barked sort. Very attractive in winter.
1 to 2 feet
$\$ .75$ each
2 to 3 feet
$1.00 \mathrm{each}$

CORNUS FLORIDA (White-flowering Dogwood). An American species of irregular habit, with spreading open top. It produces large, showy white flowers in May before the leaves appear; in autumn the grayish green foliage turns to dark red, which, with the brilliant berries, make it one of the most beautiful trees at that season.
1 to 2 feet
$\$ .75$ each
2 to 3 feet
$\$ 1.00$ each

C. PANiculata (Gray Dogwood). One of the best native shrubs; free-flowering; very handsome when in bloom, and with its white fruits on red peduncles in the fall.
1 to 2 feet
$\$ .75$ each
2 to 3 feet
$\$ 1.00$ each

C.-RUBRA (Red-flowering Dogwood). This is one of the finest flowering trees; it blooms when quite young, producing deep rose-colored flowers. 1 to 2 feet................. \$ .75 each 2 to 3 feet ................ 1.00 each

C. SANGUINEA (European Red Oiser), Branches deep red or purplish red; greenish white flowers are followed by black fruit.
1 to $2 \mathrm{ft}$.
$\$ .75$ each
2 to 3 feet.
1.00 each

C. STOLONIFERA (S preading Cornel). M. A shrub usually with dark blood-red branches and prostrate stem. Flowers in dense cymes, followed by white berries. Very showy in winter.

1 to 2 feet.................\$ \$.75 each

2 to 3 feet........................

\section{CYDONIA. Japan Quince}

CYDONIA JAPONICA. A shrub with spreading. spiny branches; glossy leaves; flowers are a deep scarlet, in clusters. The quinch-shaped, fragrant, golden yellow fruit remains a long time in summer.

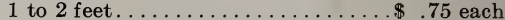
2 to 3 feet. . . . . . . . . . . $1.00 \ldots \ldots$

\section{DEUTZIA}

We are indebted to Japan for this valuable genus of plants. Their hardihood, fine habit, luxuriant foliage and profusion of attractive flowers places them among the most beautiful and most popular of flowering shrubs at the present time. Flower in June and through July and August.

CRENATA ROSEA PLENA. (Double-flowering Deutzia.) Double white, tinged with pink; very desirable tall shrub.

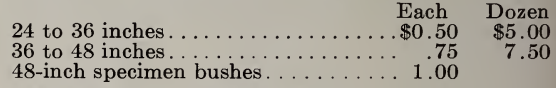

GRACILIS. A low-growing shrub with slender, graceful branches of pure white flowers; free flowering and very sweetly scented.

10 to 12 inches, bushy . . . . . . . $\begin{gathered}\text { Each } \\ \text { Do.50 }\end{gathered} \begin{array}{r}\text { Dozen } \\ \$ 5.00\end{array}$ 18 inches, bushy..................

PRIDE OF ROCHESTER. A variety of Deutzia Crenata Flore Plena and producing large, double, white flowers; back of the petals slightly tinted with rose. It excels all the older sorts in size of flower, length of panicle, profuseness of bloom and vigorous habit; blooms nearly a week earlier.

24 to 36 inches. ........... Each $\begin{gathered}\text { Dozen } \\ 36 \text { to } 48 \text { inches }\end{gathered}$

48 -inch specimen bushes. . . . . . . $1.25 \quad 12.00$

\section{DIER VILLA. Weigela}

A very desirable family of shrubs, all of which bloom tn June.

D. HYBRIDA CANDIDA (White Weigela). One of the best. Handsome light green foliage and showy pure white flowers. Blooms profusely in June and spasmodically all summer. Vigorous and fine in habit.

1 to 2 feet. . . . . . . . . . . . $\$ .75$ each

2 to 3 feet.......................... 1.00 each

3 to 4 -foot specimens . . . . . . . . 1.50 each

ROSEA. (Rose-colored Weigela.) An elegant shrub, with fine rose-colored flowers, introduced from China by $\mathrm{Mr}$. Fortune, and considered one of the finest plants he has discovered; of erect compact growth; blossoms in June.

1 to 2 feet................... \$ .75 each

2 to 3 feet..........................

3 to 4 feet. .....................

\section{FORSYTHIA. Golden Bell}

The Forsythia is indispensable as an early blooming shrub. The flowers appear in immense quantities before the leaves, completely hiding the branches. It is one of the easiest shrubs to cultivate. Prices, all varieties:

Each Dozen

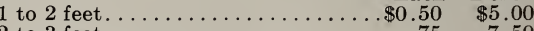

2 to 3 feet. .......................

3 to 4 -foot specimen bushes.......... $1.00 \quad 10.00$

FORS YTHIA FORTUNEI. L. Upright in habit, with broad, deep green foliage, turning to a purplish tint in the autumn; flowers deep yellow and in great profusion.

F. INTERMEDIA. L. This also is an erect-growing shrub, but when full grown the branches become arching and it resembles F. suspensa; the blossoms are much like F. Fortunei; very floriferous.

F. SUSPENSA. L. In this variety we have the weeping form with long, pendulous branches; golden yellow flowers early in April. 


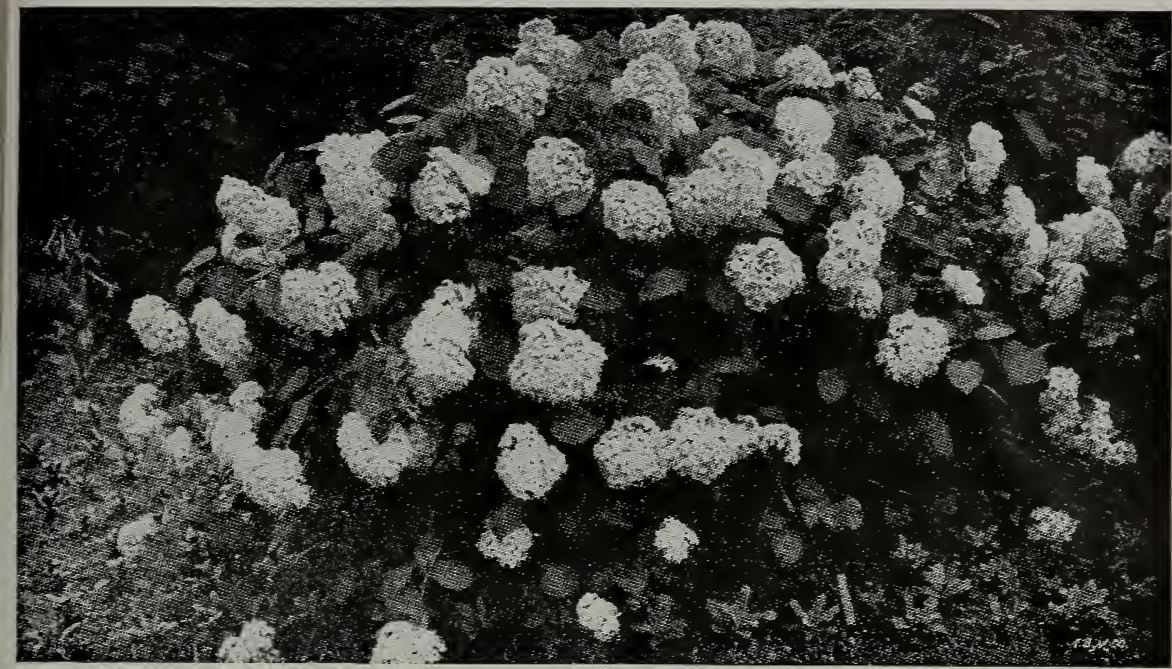

Hydrangea Arborescens

ORNAMENTAL and FLOWERING SHRUBS-Continued.

\section{HY DRANGEA \\ (The Hydrangeas)}

HYDRANGEA ARBORESCENS GRANDIFLORA.

(Snowball Hydrangea.) (Illustration above.) This magnificent, perfectly hardy American shrub has snow-white blossoms of largest size. One of its most valuable characteristics is its coming into bloom just after the passing of all the early spring shrubs, while its long flowering season, from early June until late August, makes it a valuable acquisition in any garden. Strong plants, 50 cents each; $\$ 5.00$ per dozen; specimen plants, $\$ 1.00$ each.

HYDRANGEA PANICULATA GRANDIFLORA. Without doubt the best known and most popular autumn flowering shrub in cultivation at the present time. The flowers, which are borne in dense, pyramidal panicales a foot long in the greatest profusion, are white when they first open, but gradually change to rose color, and remain in good condition for weeks. Fine bush plants, 75 cents each; $\$ 7.50$ per dozen; extra fine bush plants, $\$ 1.00$ each.

\section{KERRIA}

Corchorus (Globe Flower)

KERRIA JAPONICA VARIEGATA. A valuable shrub, bearing globular variegated flowers throughout the summer; the foliage is clear green above and pale below. 18 to 24 inches. 75 cents each.

LONICERA FRAGRANTISSIMA (Chinese Fragrant Bush Honeysuckle). A variety of strong growth, but rather straggling habit. Produces pinkish flowers in early spring, which are very fragrant. 1 to 2 feet................. $.50 \mathrm{each}$

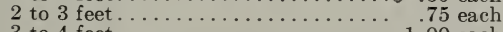

MALUS. Crab

MALUS PARKMANI. From Japan. An irregular, awkward-shaped tree when young, but a most attractive tree when filled with buds and blossoms. Each bud produces regularly five blossoms and are set on stems 3 inches long, and are so slender that they bend with the weight of the buds or bloom in a very graceful fashion. The buds are carmine in color; the open blossoms are semi-double, and the tree when in bloom presents a most gorgeous appearance.

2 to 3 feet

$\$ 1.25$ each

3 to 4 feet.

1.50 each
LONICERA. Bush Honeysuckle

IL. MORROWII (Japanese Bush Honeysuckle). A shrub with wide-spreading branches; leaves dark green above and grayish beneath; creamy white flowers in May and June, followed by bright red fruits ripening in August, and lasting until late in the fall. Very decorative.
1 to 2 feet
$\$ 0.75$ each
2 to 3 feet.
$1.00 \mathrm{each}$

IL. RUPRECHTIANA (Manuchrian Honeysuckle). Particularly valuable for its yellowish-white flowers in June, followed by showy red fruit in the autumn Foliage dark red above and grayish beneath.
1 to 2 feet
$\$ 0.75$ each

2 to 3 feet.

1.00 each

\section{PHILA DELPHUS}

(Syringa or Mock Orange)

PHILADELPHUS CORONARIUS. This variety is known as the "Garland Syringa." It is a stronggrowing shrub often 10 to 12 feet in height, very hardy, and like all the Philadelphus is one of the best shrubs for situations which are partially shaded, although preferring sun. Orange-scented, creamy-white flowers in May and June.

1 to 2 feet

2 to 3 feet

3 to 4 foot specimen bushes.

$\begin{array}{lr}\text { Each } & \text { Dozen } \\ \$ 0.50 & \$ 5.00 \\ .75 & 7.50\end{array}$

\section{SPIRAEA}

ANTHONY WATERER. A rapid grower, with upright, spreading branches and dark green foliage: very desirable for lawn decoration. Brilliant rosy-carmine flowers, in large round clusters, blooming all through the late part of the summer.

1 to 2 feet

2 to 3 feet

Each Dozen

3 foot specimen bushes ........... $1.00 \quad 10.00$

BILLARDI ALBA. A white-flowered form. 75 cents each.

OPULIFOLIA AUREA. (Golden Spirea.) One of the best of our golden-leaved shrubs. White 


\section{ORNAMENTAL and FLOWERING SHRUBS-Continued.}

flowers in clusters, produced in May. Foliage golden-yellow all summer. Each Dozen

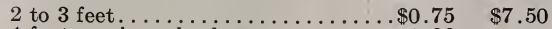

4 foot specimen bushes............ 1.00

VAN HOUTTEI. (Bridal Wreath.) By many this is regarded as the finest of all Spireas, and it is assuredly one of the most esteemed shrubs in cultivation. It forms an erect bush with graceful arching branches, well covered with neat, rich, green foliage, and in early summer a profusion of large, pure white flower clusters. Very hardy and most effective.

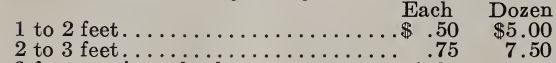

3 foot specimen bushes............. 1.00

\section{SYMPHORICARPOS}

SYMPHORICARPOS RACEMOSUS (Snowberry). Smooth shrub, with slender branches, usually bending under their load of white, waxy berries, which appear in autumn; flowers are rose-colored, in loose racemes in July and August.

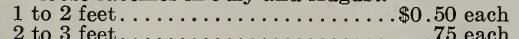

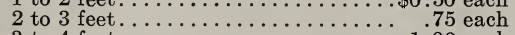

3 to 4 feet................... 1.00 each

S. VULGARIS (Indian Currant). Of more compact growth than the above; spreading, graceful habit. The flowers are greenish-red and succeeded by dark purplish red berries in clusters. Excellent for massing on hillsides or rough places.

1 to 2 feet. $2 \ldots \ldots \ldots \ldots \ldots \ldots \ldots \ldots \ldots \ldots .50 .50$ each

3 to 4 foot specimens............1.00 each

SORBUS. Mountain Ash

SORBUS AUCUPARIA (European Mountain Ash). Fine tree-bearing clusters of scarlet berries from July to winter, making it very attractive.

2 to 3 feet.................\$1.00 each

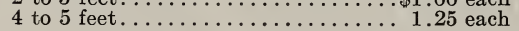

\section{SYRINGIA or LILAC}

SYRINGA VULGARIS. (Common Lilac.) One of the oldest shrubs, but still ranks among the choicest. Purple, fragrant flowers; large clusters. Flowering in May. Too well known to require description.

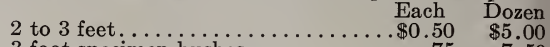
3 foot specimen bushes........... $\quad .75 \quad 7.50$

S.-ALBA (Common White Lilac). Similar to the Vulgaris. Flowers are white, appearing a week earlier than those of any other variety.

2 to 3 feet................\$0.75 each

3 to 4 feet................. 1.00 each

\section{TAMARIX. Tamarisk}

TAMARIX AFRICANA (African Tamarisk). An ornamental shrub of graceful appearance. Light feathery foliage and large, loose panicles of pinkish flowers in early summer.

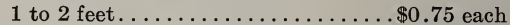

2 to 3 feet................ 1.00 each

\section{VIBURNUM. Arrow-wood}

FIBURNUM ACERIFOLIUM (Maple-leaved Viburnum). A slender, low-growing shrub, with flat heads of creamy white flowers in May. Purplecrimson berries in autumn. Grows well in shady situations. Splendid for massing.

1 to 2 feet.................. $\$ 0.75$ each 2 to 3 feet.......................

\section{WISTARIA}

WISTARIA MULTIJUGA. From Japan. Distinguished from W. Chinensis by the longer and looser racemes and smaller flowers; flowers dark purple; quite hardy.

1 to 2 feet................. \$0.75 each

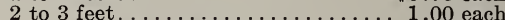

3 to 4 foot specimens............ 1.50 each

\section{Hardy Climbing Plants}

\section{HARDY CLEMATIS}

PANICULATA (Japanese Virgin's Bower). This handsome hardy climber is one of the choicest and most satisfactory climging flowering plants. Of strong rapid growth, with small, dense, cheerful green foliage, and pure white, deliciously fragrant flowers, which appear in the greatest profusion in August and September, followed by silvery feathery seed pods, which make an attractive appearance until mid-winter. The plants succeed in almost any position. Not only is it adapted to run up all kinds of supports, but is just as useful for planting among rock-work, sloping banks, covering graves, or, in fact, any position where a graceful vine or trailer is desired. Strong plants, 75 cents each; $\$ 7.50$ per dozen.

\section{LARGE-FLOWERING CLEMATIS}

No other climbing plant equals in attractiveness the beautiful large-flowering Clematis. Their requirements are somewhat different from most other plants, and proper conditions must be given to secure satisfactory results. They need rich, deep soil, perfect drainage, abundance of water and, most important of all, they should be planted with the crowns three inches beneath the surface of the soil. They seem to do best in a position where they will not be exposed to the full sun during the hottest part of the day.

ANDERSON HENRYI. Creamy-white, large.

JACKMANI. The popular rich purple variety.

Price. Either of the above, $\$ 1.00$ each.

LONICERA. Honeysuckle

LONICERA JAPONICA BRACHYPODA (Chinese Evergreen Honeysuckle). Very fragrant, yellow and cream-colored flowers; foliage dark green and almost an evergreen. 2 years. 50 cents each; 3 years, 75 cents each.
L.-HALLIANA (Hall's Evergreen Honeysuckle). Of vigorous growth; fragrant yellow and white flowers from midsummer until frost; more generally used than the other varieties. 3 years, 75 cents each.

\section{HARDY CLIMBING ROSES}

CRIMSON RAMBLER. The foliage is rich, dark green; the growth rapid and diverse, but its great beauty is when the plant is covered with a profusion of the brightest crimson, partly double flowers which remain on a long time. 75 cents each. Extra heavy, $\$ 1.00$ each.

DOROTHY PERKINS. This is a splendid new shellpink climbing Rose. It has the same strong habit of growth as the Crimson Rambler, and the flowers are borne in clusters of thirty or forty, sometimes fifty or sixty. The flowers are large for a Rose of this class, very double and sweetly scented. 75 cents each. Extra heavy, $\$ 1.00$ each.

DOROTHY PERKINS RED (Excelsa). Very double crimson-maroon flowers in large trusses. Of same habit as the above and holds its foliage better than the Crimson Rambler. 75 cents each. Extra heavy, $\$ 1.00$ each.

THE WILD ROSE or ROSE SPECIES ROS` $\wedge$ RUGOSA. L. An upright shrub, attaining 5 tu 6 feet in height. Its stout stems are densely beset with prickles; foliage shining dark green, deeply plicated; not attractive to insects; flowers single, red, fragrant and produced freely from June to December; fruit bright crimson-scarlet.

1 to 2 feet.................\$ 0.50 each

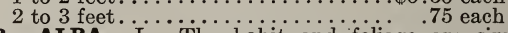

R.-ALBA. L. The habit and foliage are similar to the above, but the flowers are pure white, single and as attractive in the bud as when open; quite fragrant.

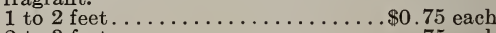
2 to 3 feet.......................... 


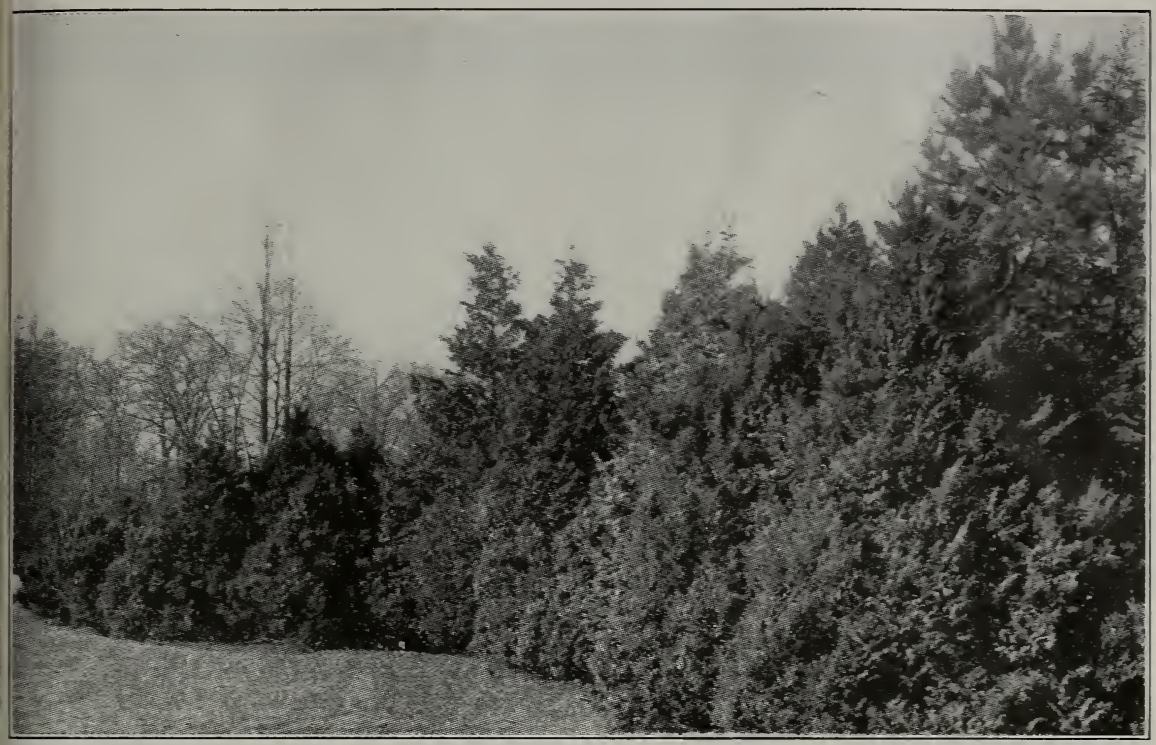

\section{Evergreen Trees}

These Evergreens are all heavily rooted, thrifty specimens, in prime condition for transplanting. Ther will be found invaluable for lawn decoration, high hedges, the filling out of corners, the hiding of objectionable objects, and many other purposes that will suggest themselres to the owner of the well-kept place. The proper time for transplanting is in the early spring.

All Evergreens will be balled and bagged and shipped by express, collect. When crating is necessary, it will be charged for at cost.

\section{ABIES. Fir.}

ABIES BALSAMEA (Balsam Fir). A slender tree of pyramidal form, and of rapid growth. Foliage dark green and silvery beneath. It thrives in moist soil best, but will grow on dry uplands. Not desirable farther south than Northern Massachusetts.

18 to 24 inches. . . .

21 to 30 inches......................... 3.00

3 feet specimens.................. 4.00

A. CANDENSIS (Hemlock). See Tsuga canadensis.

\section{JUNIPERUS. Juniper.}

\section{A Most Interesting and Desirable Family of Hardy} Everg̈reens.

JUNIPERUS HIBERNICA (Irish Juniper). Tree with dense pillar-like growth. Glaucous green foliage; with tips of branchlets erect. Each

18 to 24 inches. ....... $\$ 2.00$

24 to 30 inches $\ldots \ldots \ldots \ldots \ldots \ldots . .50$

30 to 36 inches.......................... 3.00

J.-SUECICA (Swedish Juniper). Grows mueh like the Irish Juniper; but hardier. Foliage sharp; rather long spreading leaves, the branches drooping at the tips.

24 to 30 inches .................... $\$ 2.50$

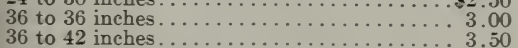

\section{PICEA. Spruce.}

PICEA PUNGENS (Green Colorado Spruce). Lm. A slow-growing, hardy conifer of symmetrical habit; will thrive near the salt water as can no other variety of conifer, consequently admirably adapted to seashore planting. A very beautiful evergreen. Specimens of larger sizes can be furnished if desired.
18 to 24 inches.

21 to 30 inches

36 to 42 inches.

42 to 48 inches.

Each

$\$ 1.50$

2.50

3.50

5.00

PUNGENS VAR GLAUCA (Colorado Blue Spruce) A glaucous form of Picea pungens; same general characteristics as above, with the exception that instead of being green it has an exceedingly rich silvery-blue color. Tery desirable for a specimen tree on any lawn; easily transplanted. Specimens in larger sizes up to 10 feet can be furnished upon application. Each 12 to 18 inches

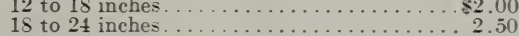
24 to 30 inches . . . . . . . . . . . . . . . . 3.00

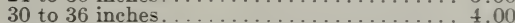

PUNGENS KOSTERI (Koster's Blue Spruce). Same general characteristics as the above, varying in this respect only, that they are of uniform color deep silvery-blue. Compact habit of growth; vers: symmetrical and most desirable of all. Larger specimens when wanted. 18 to 24 inches . . . . . . . . . . . . . . . . $\$ 3.00$

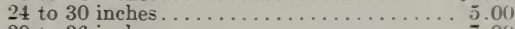

30 to 36 inches ................... 7.00

PSEUDOTSUGA. Douglas Spruce.

PSEUDOTSUGA TAXIFOLIA (Douglas Spruce). One of the most desirable of evergreens, considered from every standpoint. When small, it is beautiful in shape and texture, and when it attains large proportions, it is majestic. Leaves dark bluish green; rapid grower, and healthy; worthy of a place on every estate. Prices for larger specimens on application. 18 to 24 inches 24 to 30 inches

30 to 36 inches

Each

36 to 4 inches. 
EVERGREEN TREES-Continued.

PINUS. Pine.

PINUS BANKSIANA, syn, divaricata (Jack Pine). A tree that will thrive on poorest and driest soils; very rapid grower; desirable for screening purposes. Somewhat irregular habit of growth.

3 to 5 feet

5 to 8 feet

Each

3.50

P. MUGHUS (Dwarf Mountain Pine). Very valuable where a low, dense, spreading growth of evergreen is desired; foliage deep green; very hardy. A most useful tree for lawn decoration, for rock-work, or covering hillsides.

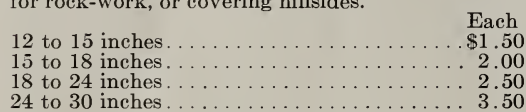

P. SYLVESTRIS (Scotch Pine). One of the most rapid-growing of the conifers; decidedly beautiful and useful for screening purposes. In this country it is not a long-lived tree; when twenty-five or thirty years old it begins to show age, consequently other trees should be planted with it to ensure permanence. The foliage bluish-green.

24 to 30 inches.

30 to 36 inches.

36 to 48 inches.

Each

$\$ 1.50$

2.00

\section{RETINISPORA. Japan Cypress.}

RETINISPORA PLUMOSA (Plume-like Japan Cypress). A tree with soft, plume-like feathery foliage; light green in color; very graceful in habit of growth. To be kept at its best it should be sheared in the middle of June. In that event it will not become open and ragged.

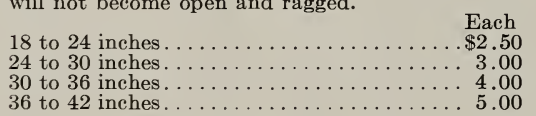

RETINISPORA, PLUMOSA AUREA. Golden form of Retinispora plumosa. General description and prices the same as the foregoing.

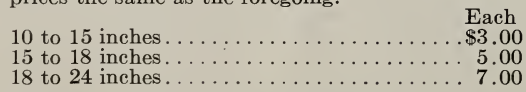

R. SQUARROSA (Squarrose-leaved Japan Cypress). A choice ornamental tree of Japanese origin, with a bluish-gray foliage. Very graceful and pretty. It should be planted in somewhat sheltered positions, and will repay attention given it.

\section{RECOMMENDED COLLECTION OF SIX SHOW AND FANCY DAHLIAS, For $\$ 1.00$ prepaid.}

Name

Empress of Australia. Yellow, slightly tipped, $\$$ Price Globe de Nantes. Bright scarlet. .

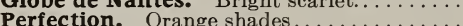

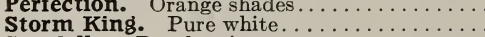

Stradella. Purple-crimson.

vivian. White and rose-violet.

$\begin{array}{r}.25 \\ .35 \\ .25 \\ .25 \\ .20 \\ .25 \\ \hline\end{array}$

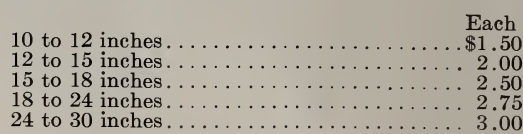

TAXUS. Yew.

This is a family of low, slow-growing evergreens that are somewhat expensive; but worthy of a place on every gentleman's estate where something choice is desired.

TAXUS CANADENSIS (Canadian Yew). A prostrate shrub with wide-spreading, slender branches; brown bark; foliage pretty dark green; showy.

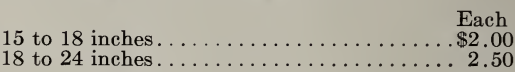

\section{THUYA. Arborvitae.}

THUYA OCCIDENTALIS (American Arborvitæ) The common upright, densely branched evergreen, so commonly used as single specimens, hedges, and windbreaks. Thrives on moist land as well as on dry. Stands close pruning.

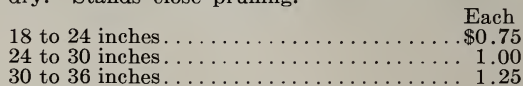

THUYA ORIENTALIS. A slim, close-growing variety of Arbor-Vitæ.

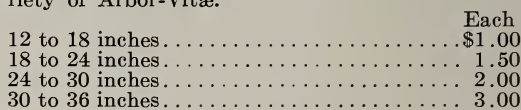

TSUGA. Hemlock.

TSUGA AMERICANUS (American Hemlock).

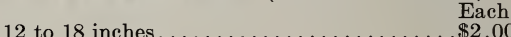

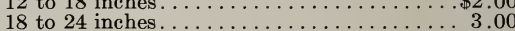

24 to 30 inches.................... 4.00

TSUGA CANADENSIS (Hemlock). A broadly pyramidal, medium-sized tree of dense growth, with rich green foliage; branched thickly set, with more or less pendulous tendency, giving a particularly graceful effect to the whole; choice as a single lawn tree, or for hedge purposes, succeeding in all except particularly bleak situations.

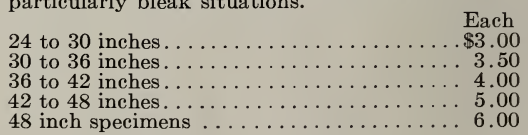

\section{RECOMMENDED COLLECTION OF} SIX UP-TO-DATE PEONY-FLOWERED DAHLIAS For $\$ 5.00$ prepaid.

Name

Regular price Attraction. Lilac-rose.............. \$1.00

Carl Purdy. Fiery scarlet. . . . . . . . . . . . 2.00

Caecilia. Pale yellow.................. $\quad .50$

Latona. Salmon-buff shades................ 1.00

Mrs. Bowen Tufts. Rosy-purple . . . . . . . . 1.00

South Pole. Pure white................. 1.50

$\overline{\$ 6.00}$ 


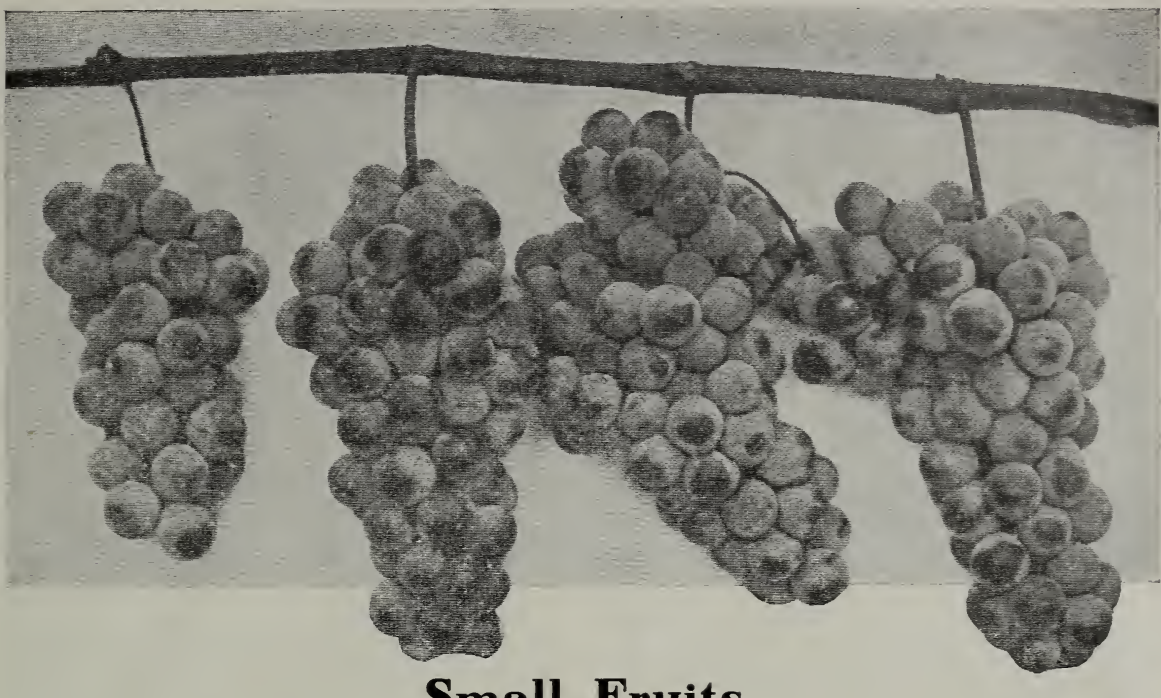

\section{Grape Vines}

We will ship all Grape Vines prepaid, at prices quoted. Our Grape Vines are strong, three-year old vines of the finest quality.

CAMPBELL'S EARLY. Black. Cluster large and shouldered, moderately compact; very early and productive. This is claimed to be the finest Grape that has been produced in a long time. It makes a strong growth, with abundant thin, healthy foliage. Quality about the same as Concord. \$1.00 each.

\section{STANDARD VARIETIES of GRAPES}

CONCORD. Black. Early; decidedly the most popular Grape in America, and deservedly so. Bunch, large, shouldered, compact; berries large, covered with a rich bloom; skin tender, but sufficiently firm to carry well. Succeeds everywhere. 35 cents each; $\$ 2.50$ per dozen.

DELAWARE. Red. Compact bunch, very delicious; always bringing the highest price in market and always considered the best for home use. Berries small; skin thin, but firm. Ripens with Concord or a little before. It should be in every garden. 50 cents each; $\$ 5.00$ per dozen.

MOORE'S EARLY. Black. Bunch rarely shouldered, not quite so large as Concord; berries larger and very much like it in flavor and quality. Ripens so early as to be nearly out of the market before Concord starts in, therefore a very popular early market variety. Succeeds best on rich soil. $\mathbf{5 0}$ cents each; $\$ 5.00$ per dozen.

NIAGARA. White. Bunch very large and handsome, often shouldered, compact; berries large, round; skin thin, tough, does not crack and carries well; has not much pulp when fully ripe; melting, sweet, with a flavor and aroma peculiarly its own and agreeable to most tastes; ripens with Concord. Succeeds everywhere and is a farorite with every grower and buyer. 50 cents each; $\$ 5.00$ per dozen.

POCKLINGTON. Pale green. Usually with a tinge of golden yellow where exposed to the sun; bunch large, compact; berries large, covered with a beautiful white bloom; flesh juicy, sweet, with considerable pulp. Foliage large and healthy. A seedling of the Concord, ripening soon after. 50 cents each; $\$ 5.00$ per dozen.
SALEM. (Rogers' No. 53.) Red. One of the best and most popular of the Rogers; ripens with the Concord. 50 cents each; $\$ 5.00$ per dozen.

WORDEN. Black. Bunch large, sometimes shouldered; compact; berries very large, skin thin. Superior to the Concord in the following points: Better quality, larger berries, more compact, and ripens five to ten days earlier. Fully equals Concord in vigor, health and productiveness. 50 cents each; $\$ 15.00$ per dozen.

\section{Rhubarb}

RHUBARB or PIE PLANT. For family or market. Plant 12 to 18 inches apart in rows. Shipped at purchaser's expense.

COLOSSAL. Early, tender and very large. 25 cents each; $\$ 2.50$ per dozen.

Extra large plants for forcing in greenhouses. 50 cents each; $\$ 5.00$ per dozen, express collect.

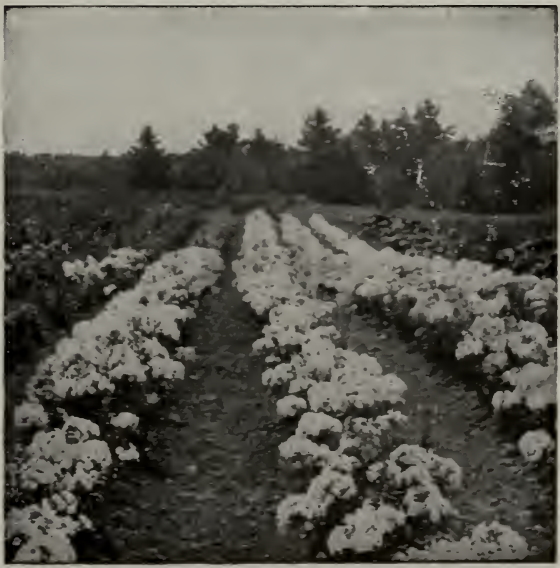

Hardy Phlox in My Nurseries. 


\section{Fruit Trees}

\section{All Fruits Shipped by Express at Purchasers' Expense}

\section{Apples}

Standard Tree, 4 to 6 feet, $\$ 1.00$ each; $\$ 10.00$ per dozen, except where otherwise priced.

ALEXANDER. Fall apple. A Russian apple of very large size with beautifully striped or stained red skin and white, crisp flesh, tender, juicy, and sub-acid. Tree is large and vigorous, bearing heavy crops. Ripening September and October.

BALDWIN. Vigorous growth; large, bright red; crisp juicy, sub-acid. The most popular and profitable market variety. Ripening December to March.

DUCHESS OF OLDENBURG. Vigorous growth; Russian; large, striped, tender, juicy, sub-acid; regular and abundant bearer. One of the hardiest varieties grown. Ripening September.

EARLY HARVEST. Very early; fruit medium size, pale yellow, tender, juicy, sub-acid. Ripening August. Tree is vigorous grower.

FAMEUSE or SNOW. Vigorous growth; medium size, deep erimson; tender, sub-acid, melting, delicious; very good; hardy. One of the best dessert apples. Ripening November to January.

MAIDEN'S BLUSH. Free growth; large, pale lemon with crimson cheeks; flesh white, tender and crisp, sub-acid. Tree vigorous and good bearer. Ripening September and October.

McINTOSH RED. Color is bright, deep red; flesh white with pinkish tinge; juicy with slight acid flavor. Hardy. Ripening November to February. $\$ 1.25$ each.

NORTHWESTERN G R E E N I N G. Fall Apple. Round; very large; greenish-yellow, extremely hardy, vigorous; bears very young. Ripening September.

RED ASTRACHAN. Large, roundish; yellow with dark red patches; flesh decidedly acid and juicy; highly esteemed on account of its fine appearance, earliness and hardiness. Ripening July and August.

RHODE ISLAND GREENING. Vigorous growth; large, green, fine grained; rich, sub-acid; very good. Ripening December to April.

ROME BEAUTY. Moderate growth, large, round; mottled and striped in different shades of red; flavor and quality way above the average; appearance and size are its valuable points; tender, juicy, sprightly, sub-acid. Ripening December to May.

SPITZENBERG. (Esopus.) Large, round, dark red with gray dots; firm, rich, crisp, juicy, spicy and delicious. Ripening December to April.

STARK. (Pride of Maine.) An early and abundant bearer; fruit large and valued for its long keeping; skin greenish-yellow, shaded and striped red, thinly covered with light brown dots; flesh yellow, moderately juicy, mild. Ripening January to May.

STAYMAN'S WINESAP. A dark, rich, red Apple with indistinct stripes; flesh yellow, not in the least mealy, plenty of juice; firm. Ripening November to April.

SUTTON BEAUTY. Free growth; medium to large; yellow and crimson; tender, juicy, subacid; very good and a long keeper. Ripening November to April.

TALMAN'S SWEET. Free growth; medium; bright yellow with a few dots; flesh white, firm, rich, sweet. Ripening November to April.

WAGENER. Vigorous growth, medium to large; yellow and crimson, fine texture, high flavor and excellent quality, juicy and sub-acid. Ripening December to March.
WEALTHY. Fall Apple. Tree growth, medium size; dark red; flesh white or a little stained; tender, crisp, juicy, fine grained, aromatic and very good. Ripening December to February.

YELLOW TRANSPARENT. Free growth; medium, roundish, oblate, slightly conical; pale yellow; tender, juicy, sprightly sub-acid, fine flavor, good. Ripening August.

\section{Crab Apples}

Standard Tree, 4 to 6 feet, $\$ 1.00$ each; $\$ 10.00$ per dozen.

HYSLOP. Large size; dark crimson with bloom; very showy, and to my knowledge the best of this class.

\section{Cherries}

Standard Trees, 2 to 3 years, $\$ 1.00$ each, $\$ 10.00$ per dozen.

BLACK TARTARIAN. Sweet; vigorous growth; very large; purplish black. One of the best. Ripening end of June.

EARLY RICHMOND. Sour. Medium size; dark red; juicy, rich acid flavor. The stone adheres to the stem. One of the most valuable sour Cherries.

MONTMORENCY. Sour. Beautiful, large, red, acid Cherry; very hardy; productive.

NAPOLEON. Sweet. Vigorous growth; very large; pale yellow with red cheek; firm, juicy and sweet; very good. Ripening first of July.

\section{Pears}

\section{Standard Trees, 3 to 4 feet, $\$ 1.00$ each.
$\$ 10.00$ per dozen.}

BARTLETT. Yellow with red cheek; productive and of luscious flavor.

BEURRE DOSC. Large; cinnamon russet; rich and delicious. One of the best.

BEURRE D'ANJOU. Large; greenish russet; flesh melting; splendid flavor.

CLAPP'S FAVORITE. A popular variety; large; yellow and red; sweet and melting.

DUCHESS D'ANGOULEME. Very large; greenish-yellow, dull red cheek; vigorous grower; good bearer.

LAWRENCE. Above medium size; yellow; excellent quality. One of the best early winter Pears.

SECKEL. Small; yellowish-brown; decidedly spicy flavor.

SHELDON. Large; very juicy, melting, sweet and vinous. A fine grower and good bearer. Ripening October and November.

\section{Plums}

Standard Tree, 4 to 5 feet, $\$ 1.50$ each.

ABUNDANCE. Large; bright red, yellow cheeks; flesh light yellow, very juicy and sweet. Early annual and profuse bearer. Ripening September.

BURBANK. Of Japanese origin. Large; clear cherry red; good quality; hardy, productive. Ripening August.

RED JUNE. Of immense value for its early ripening. Fruit medium to large; deep purplish red. Flesh pale yellow. One of the best. Ripening August.

\section{Quince}

Standard Quince, 3 to 4 feet, $\$ 1.25$ each.

ORANGE. Fruit large; roundish; bright golden yellow; very productive. 


\section{Flower Seed}

Ageratum, Mexicanum............... 0.

Aster, tall mixed varieties.............

Aster, Dwarf mixed varieties.

Aster, branching Comet. .......

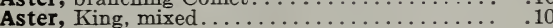

Aster, branching, white . . . . . . . . . . . . . . . .

Balsam, double mixed............... . 05

Balsam, Camellia Fld.................. .10

Bachelor's Button, mixed............. .05

Brachycome...........................

California Poppy, mixed ................... .05

Calendula, mixed............... $\quad .10$

Calliopsis, mixed. . . . . . . . . . . . . . .

Carnation, Marguerite

Carnation, choice mixed

Candytuft, mixed colors

Candytuft, white.

Canterbury Bells, single

Chrysanthemum, Annual

Cockscomb, fine mixed

Cosmos, mixed.

Cypress Vine, mixed color

Datura, mixed.

Double Daisy

Evening Primrose

Everlastings, mixed.

Evening Glory.

Forget-Me-Not

Four O'clock, mixed colors

Gaillaedia, new double. .

Globe Amaranth

Godetia, finest double

Hollyhock, finest double.

Hyacinth Bean .

Larkspur, double branching

Love in a Mist, Nigella

Marisold, French, dwarf.

Marigold, African, tall

Mignonet te, large flowering

Morning Glory, mixed color

Morning Glory, Royal Jap.

Mourning Bride, dwarf doubl

Nasturtium, tall.

Nasturtium, dwarf

Nemophila, mixed varieties.

Nicotiana, mixed.

Pansy, choice mixed.

Pansy, finest show or fancy

Petunia, mixed.

Petuhia, reined and mottled.

Petunia, fancy hybrids

Phlox Drummondi, mixed.

Phlox, Star of Quedlinburg

Pinks, double Imperial.

Pinks, choice mixed.

Poppy, mixed varieties.

Portulaca, single mixed.

Portulaca, extra double.

Ricinus, sanguineus.

Salpiglossis, Choice mixed

Salvia.

Scarlet Flax

Snapdragon, single mixed

Stock, German ten weeks

Sunflower, finest double.

Sweet Alyssum.

Sweet Peas, mixed colors

Sweet Peas, Spencer's

Sweet Sultan, mixed colors

Sweet William, fine mixed.

Thunbergia, mixed varieties

Verbena, mixed colors. .

Verbena, choice mixed.

Zinnia, double, mixed.

Sweet Peas, named varieties.

Brilliant Blue.

Dorothy Eckford, White

Janet Scott, Pink-

King Edward VII, C......

Lady G. Hamilton, Lavender..................

\section{Dahlia Seed}

I offer this year Mixed Seed carefully selected from the best varieties of all types. If you are interested in growing Dahlias in new forms and new colors you cannot do better than to get a package of this seed. Price, 25 cents per package.

\section{Wooden Plant Labels}

For any kinds of plants. These are plain labels to be used either in pots or out of doors, with one end pointed. I am also offering Dahlia labels which are suitable for labeling all kinds of Dahlias.

Plant Labels -4 inch, plain: 30 cents per 100, prepaid; $\$ 1.25$ per 1,000 , express collect. 5 -inch, plain, 35 cents per 100 , prepaid; $\$ 1.50$ per 1,000 . express collect. 6 -inch, plain: 50 cents per 100 , prepaid; $\$ 1.75$ per 1,000 , express collect.

Dahlia Labels, Painted, with Wires $-3 \frac{x}{2}$-inch, iron wire: 50 cents per 100 , prepaid; $\$ 2.00$ per 1,000 , express collect. $3 \frac{1}{2}$-inch, copper wire, 60 cents per 100, prepaid; $\$ 2.25$ per 1,000, express collect.

Dahlia Labels, Plain with Wires-3 $\frac{1}{2}$-inch, iron wire: 35 cents per 100 , prepaid; $\$ 1.50$ per 1,000 , express collect. $3 \frac{1}{2}$-inch, copper wire, 50 cents per 100 , prepaid; $\$ 12.00$ per 1,000 , express collect.

\section{Vermine}

For Greenhouses, Gardens, Lawns, Tennis Courts and Golf Links. Destroys White Grubs, Cut, Eel. and Wire Worms, Slugs, Maggots, Root Lice and Ants. Directions for application on each package. Applied in watering can or with sprayer.

Size

Prepaid

1 Quart. . . . . . . . . . . . . . . . . . \$2.00

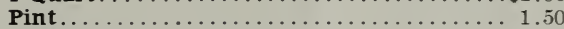

Half-pint . . . . . . . . . . . . . . . 1.00

Quarter-Pint . . . . . . .

\section{RECOMMENDED COLLECTION}

HYBRID CACTUS DAHLIAS

\section{SIX GIANT DAHLIAS FOR $\$ 4.00$ prepaid.}

Name

Attraction. Lilac-rose.

Regular Price

Attraction. Lilac-rose.

$\$ 1.00$

Mrs. C. H. Breck. Yellow and pink ..... .50

Mrs. Warnaar. White shade.......... 1.00

Kalif. Crimson-scarlet ................. 75

Yellow King. Yellow............. 1.00

$\overline{\$ 5.25}$

NEW AND UP-TO-DATE CACTUS DAHLIAS.

This recommended collection of Six for $\$ 10$ prepaid. Name

$\$ 10$ prepaid.
Regular price

Bowen Tufts. Orange and yellow....... \$5.00

H. H. Thomas. Deep crimson. . . . . . . . . . .75

Lavinia. Coppery-red . . . . . . . . . . . . . 1.00

Masterpiece. Coral-pink. . . . . . . . . . . . 2.50

Mrs. Brandt. Salmon-buff, large........... 1.50

Natalie Alsop. Rose-pink............. 2.00 


\section{NEW STRAWBERRY!}

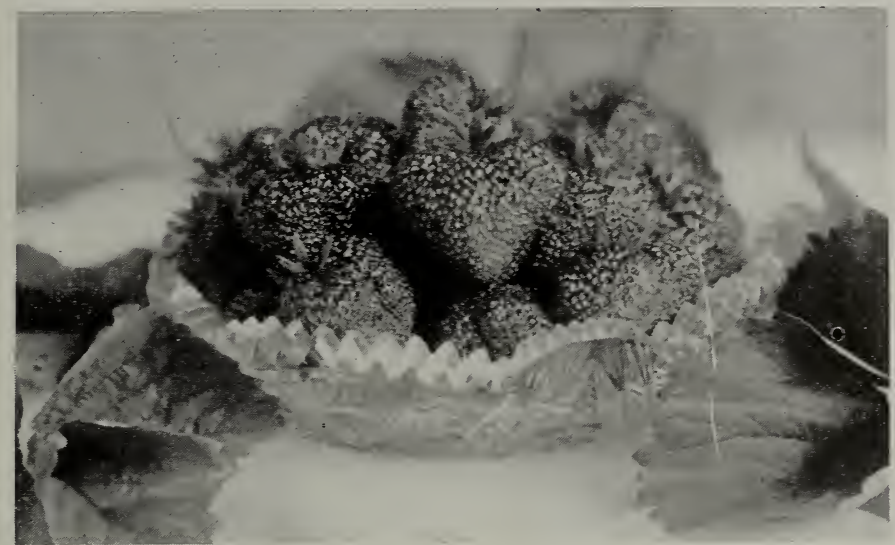

Plants of the now famous St. Martin Strawberry will be for sale in the spring of 1920 . The Massachusetts Horticultural Society, in 1914, awarded to this wonderful berry the Silver Medal, its highest award for a new stramberry, and every year since has awarded cash prizes to St. Martin in competition with all other varieties exhibited.

After eleven years proof of unvarying supremacy in size, color, flavor and productivity, this Strawberry is now to be put upon the market.

For free circular, write to

LOUIS GRATON, Originator and Sole Owner.

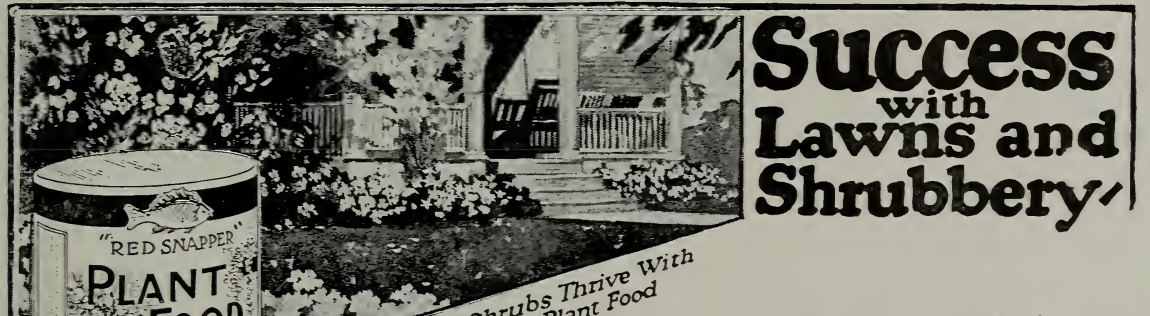

Flowering plants in pots garden vases, window boxes, hedges, etc., also climbing vines and lawn shrub-

bery, in order to live, thrive and flourish, shou!d be fed on a rich and nutritious, readily assimilated and easily digested organic plant food, applied at regular intervals. It should not be merely a chemical stimulant, but a food that will make plant life itself and that will bring rich-colored, healthy foliage and verdure and an aburdance of highly colored, well marked and beautiful flowers.

\section{RED SNAPPER PLANT FOOD}

Red Snapper Plant Food is a worderfully rich, very nutritious, yet harmless fertilizer for plants of this kind. Its effects can be noticed within a few days after the first application. Color of foliage becomes a darker green and flowers and blossoms take on a beauty of coloring and size beyord all expectations---the worder and admiration of all who see them. Put up in 2-1b. cans including an 8-oz. package of Red Snapper Plant Tonic which is used to give the plants quicker start. Price, 75 cents, prepaid. 


\section{OR D ER SHEET . ISSUED BY \\ J. K. Alexander, "The Dahlia King" \\ East Bridgewater, Mass.}

Date

Amount Inclosed.

Your Name

(Please write distinctly.)

P. 0 .

Street

State

County

Orders for less than $\$ 5.00$ can be sent in stamps.

Quantity.

DESCRIPTIÓN.

Price.

Would appreciate the names and addresses of your friends who grow Dahlias. 